$6-1-2021$

\title{
Inclusion of family planning within the National Health Insurance benefits package in Ghana: A health facility assessment
}

\author{
Population Council \\ Ministry of Health \\ Ghana Health Service \\ National Health Insurance Authority \\ Marie Stopes International Ghana
}

Follow this and additional works at: https://knowledgecommons.popcouncil.org/departments_sbsr-rh

Part of the Health and Medical Administration Commons, Health Policy Commons, and the Public Health Commons

How does access to this work benefit you? Let us know!

\section{Recommended Citation}

Population Council, Ministry of Health, Ghana Health Service, National Health Insurance Authority, and Marie Stopes International Ghana. 2021. "Inclusion of family planning within the National Health Insurance benefits package in Ghana: A health facility assessment," research report. Accra: Population Council. 
RESEARCH

REPORT

JUNE 2021

INCLUSION OF FAMILY PLANNING WITHIN

THE NATIONAL HEALTH INSURANCE

BENEFITS PACKAGE IN GHANA:

A HEALTH FACILITY

ASSESSMENT

\section{population




\section{POPULATION \\ COUNCIL \\ Ideas. Evidence. Impact.}

The Population Council confronts critical health and development issues-from stopping the spread of HIV to improving reproductive health and ensuring that young people lead full and productive lives. Through biomedical, social science, and public health research in 50 countries, we work with our partners to deliver solutions that lead to more effective policies, programs, and technologies that improve lives around the world. Established in 1952 and headquartered in New York, the Council is a nongovernmental, nonprofit organization governed by an international board of trustees.

Population Council

204 Yiyiwa Drive, Abelemkpe

Accra, Ghana

Digital address: GA-124-5840

Tel: +233 $302780711 / 2$

Fax: +233 302780713

email: info.ghana@popcouncil.org

Mailing Address:

P. O. Box CT 4906

Cantonment

Accra, Ghana

popcouncil.org 
This report presents findings of the Health Facility Assessment in preparation for the inclusion of family planning within the National Health Insurance benefits package in Ghana. This assessment was implemented by the Population Council, Ministry of Health, Ghana Health Service, National Health Insurance Authority, and Marie Stopes International Ghana.

The Population Council received a grant to evaluate the pilot inclusion of family planning within the National Health Insurance Benefits Package in Ghana and conduct this health facility assessment from the Bill \& Melinda Gates Foundation. However, the views expressed do not necessarily reflect the official policies of the Foundation.

Suggested citation: Population Council, Ministry of Health, Ghana Health Service, National Health Insurance Authority, and Marie Stopes International Ghana. 2021. "Inclusion of Family Planning within the National Health Insurance Benefits Package in Ghana: A Health Facility Assessment," Research Report. Accra, Greater Accra, Ghana: Population Council.

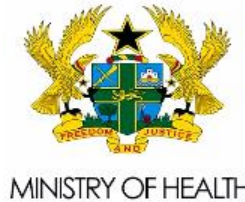

MINISTRY OF HEALTH REYUBLCOF GHANA

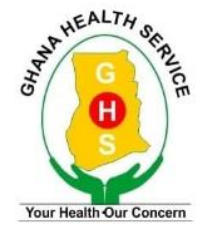

\section{S}

MARIE STOPES GHANA

Children by choice, not chance

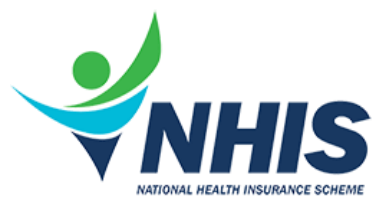

POPULATION

COUNCIL

Ideas. Evidence. Impact. 


\section{TABLE OF CONTENTS}

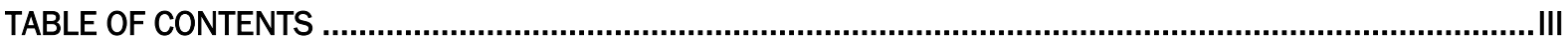

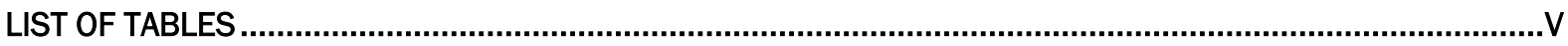

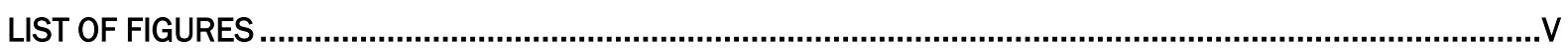

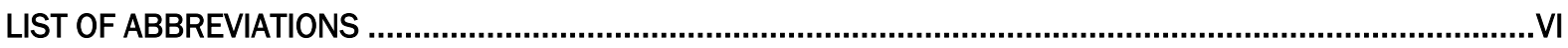

PREFACE............................................................................................................................................VII

EXECUTIVE SUMMARY ............................................................................................................... VIII

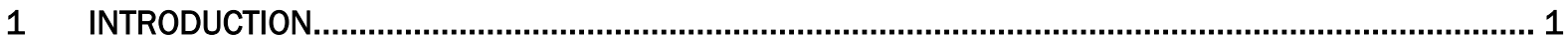

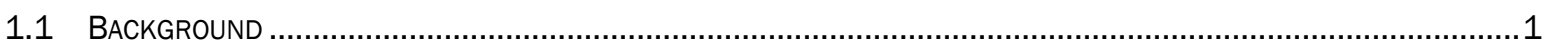

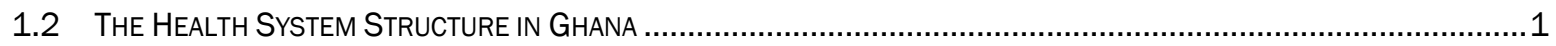

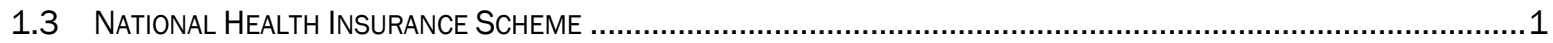

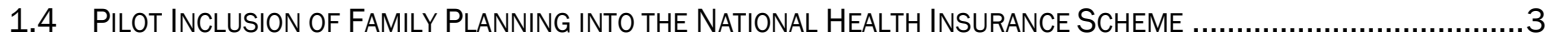

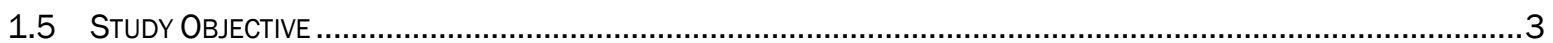

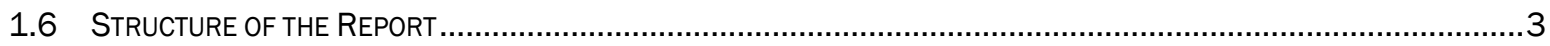

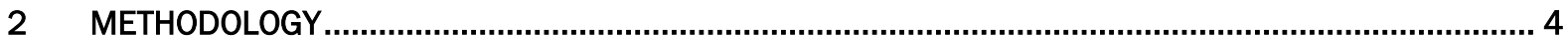

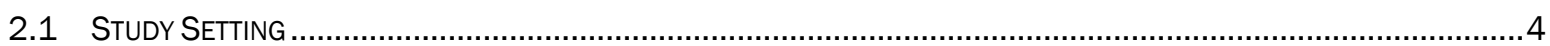

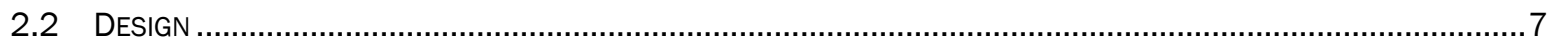

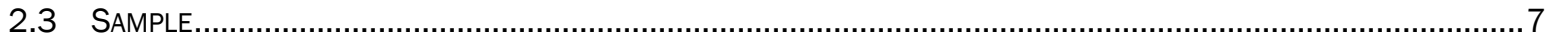

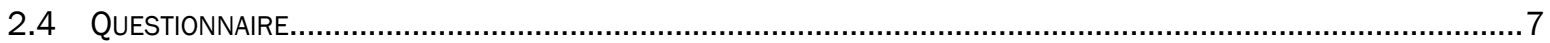

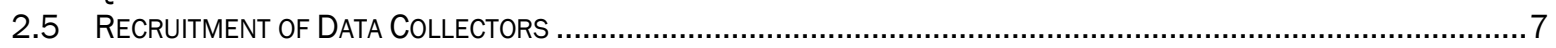

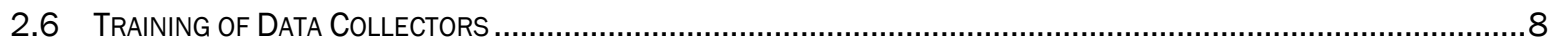

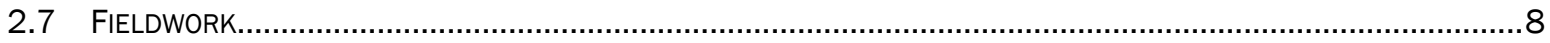

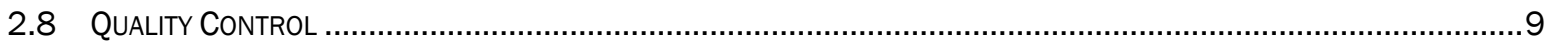

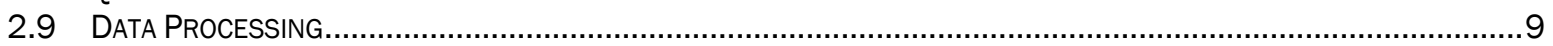

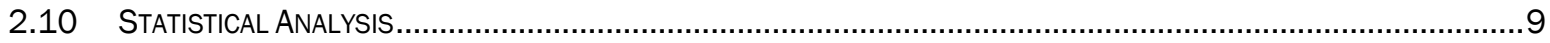

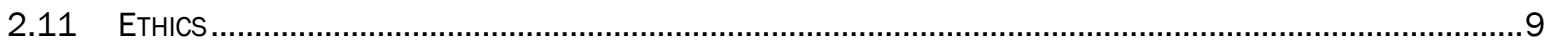

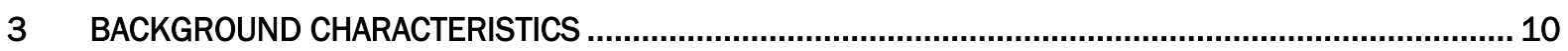

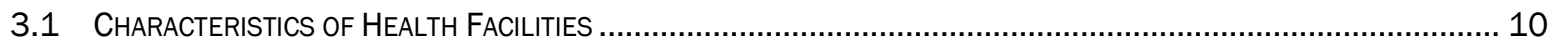

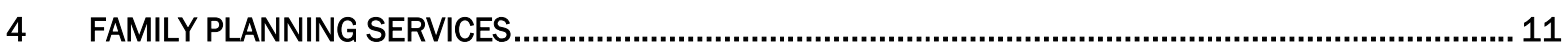

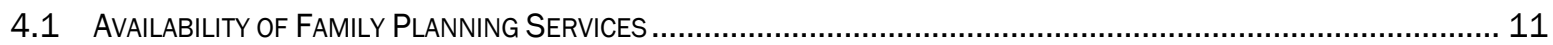

4.1.1 Family Planning Methods/Services Provided .................................................................... 11

4.1.2 Availability of a Sign Indicating the Provision of Family Planning Services and Frequency of

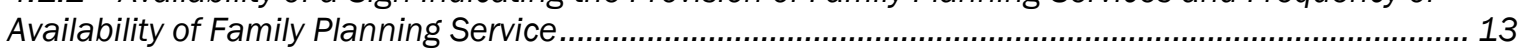

4.2 PROVISION OF FAMILY PLANNING SERVICES ................................................................................. 15

4.2.1 Designated Area for Family Planning Service Provision ................................................ 15

4.2.2 Rooms for Family Planning Service Provision........................................................................ 18

4.2.3 Evidence of Availability of Family Planning Materials .............................................................20

4.2.4 Availability of Materials for Family Planning Counseling ....................................................... 22

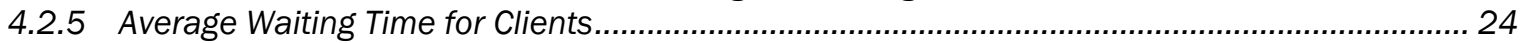

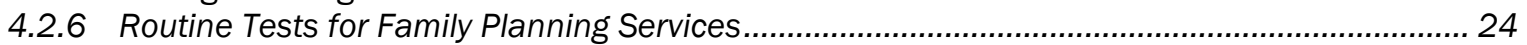

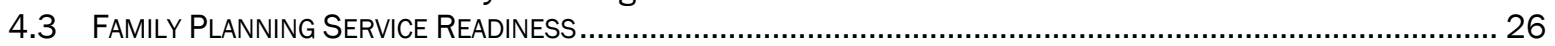

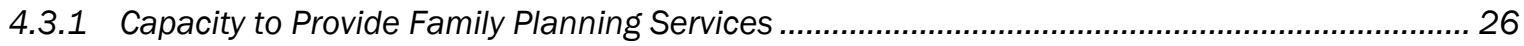

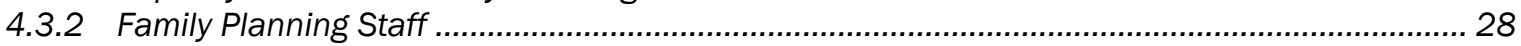

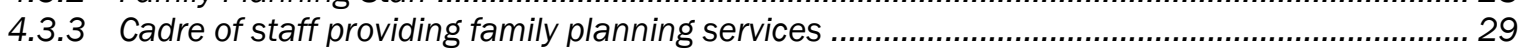

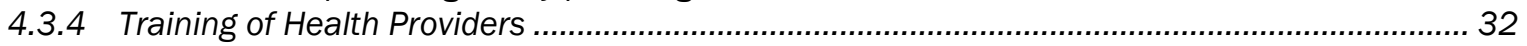

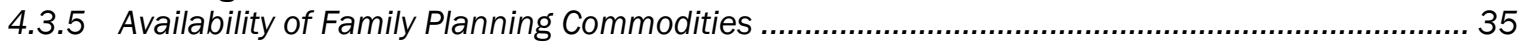

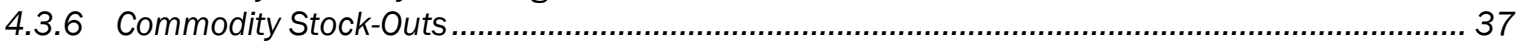

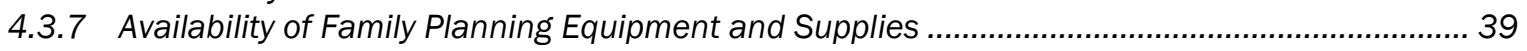

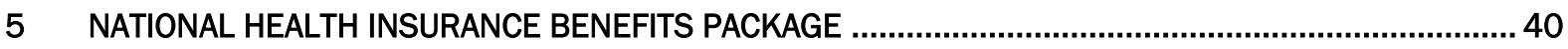

5.1 Provision of Health Services Under the National Health InSURANCE Benefits Package.........................40

5.2 TRAINING ON NATIONAL HEALTH INSURANCE SCHEME CLAIMS ........................................................... 42 
5.3 InCLusion of Family Planning into the National Health InSURANCE SCHEME PACKage

5.3.1 Provision of Family Planning Within the National Health Insurance Scheme Package ............. 42

5.3.2 Willingness to Provide Family Planning within the National Health Insurance Scheme Package 45

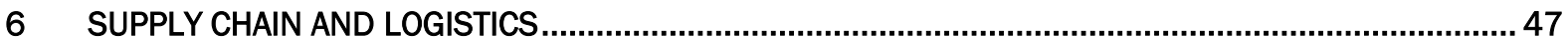

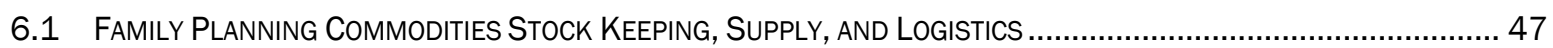

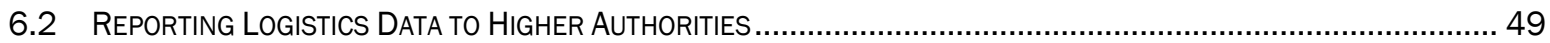

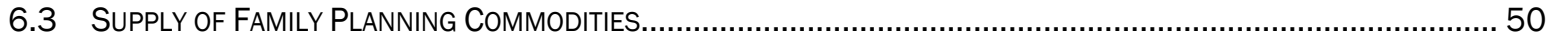

6.4 DETERMINATION OF RE-SUPPLY OF FAMILY PLANNING COMMODITIES ...................................................... 52

$7 \quad$ REGISTRY OF FAMILY PLANNING SERVICE DATA ..................................................................... 54

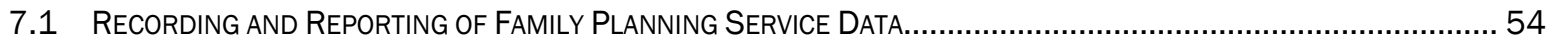

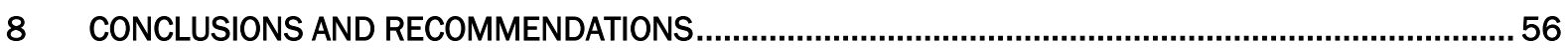

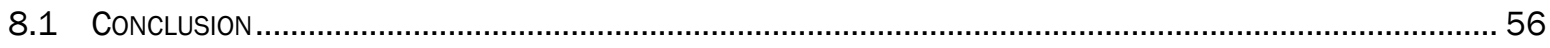

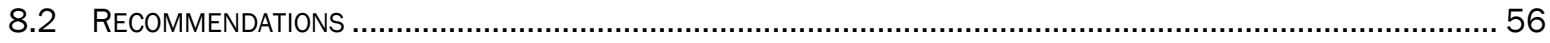

APPENDIX 1: PERSONS INVOLVED IN THE HEALTH FACILITY ASSESSMENT SURVEY .................................57

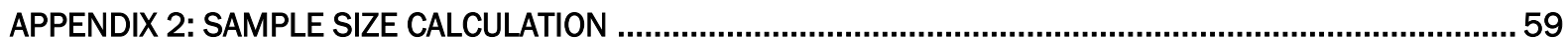

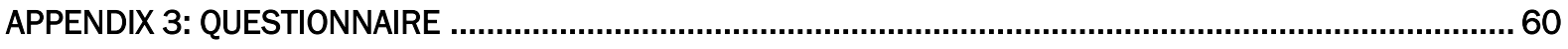




\section{LIST OF TABLES}

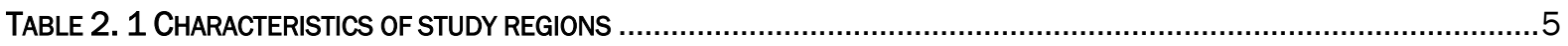

TABLE 3. 1: BACKGROUND CHARACTERISTICS OF HEALTH FACILITIES............................................................. 10

TABLE 4. 1 AVAILABILITY OF FAMILY PLANNING SERVICES .......................................................................... 12

TABLE 4. 2 AVAILABILITY OF A FAMILY PLANNING SIGN, AND NUMBER OF DAYS IN A WEEK AND HOURS IN A DAY FAMILY PLANNING

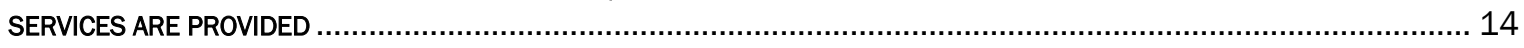

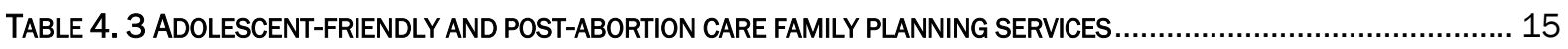

TABLE 4. 4 DESIGNATED AREA FOR FAMILY PLANNING SERVICE PROVISION AND RELATED AMENITIES ............................... 17

TABLE 4. 5 ROOMS, PRIVACY, AND CONFIDENTIALITY IN FAMILY PLANNING SERVICE PROVISION ....................................... 19

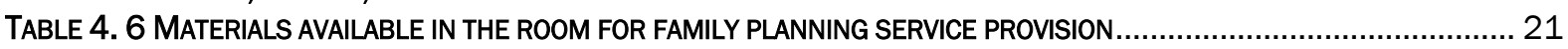

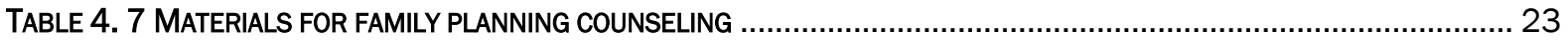

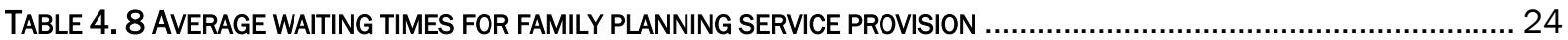

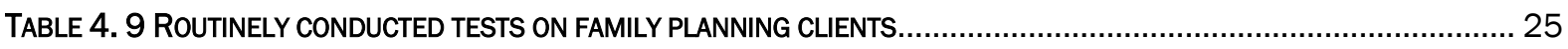

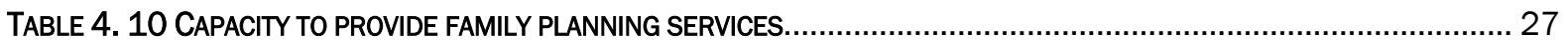

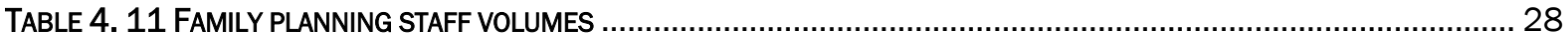

TABLE 4. 12A STAFF PROVIDING LONG-ACTING REVERSIBLE CONTRACEPTIVES AND PERMANENT METHODS ......................... 30

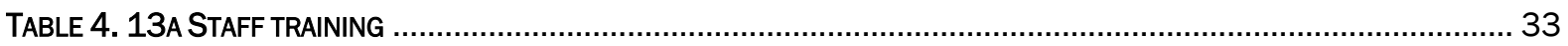

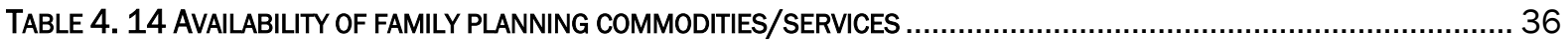

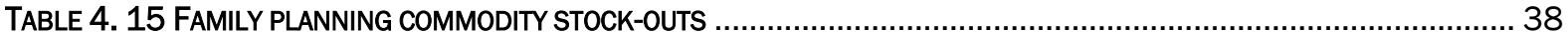

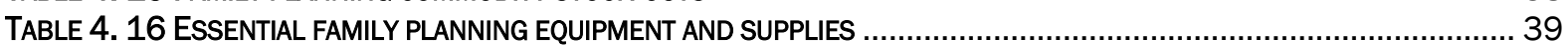

TABLE 5. 1 PROVISION OF HEALTH SERVICES UNDER THE NATIONAL HEALTH INSURANCE SCHEME ..................................41

TABLE 5. 2 TRAINING ON NATIONAL HEALTH INSURANCE SCHEME CLAIMS PROCESSING ..............................................42

TABLE 5. 3 PROVISION OF FAMILY PLANNING UNDER THE NATIONAL HEALTH INSURANCE SCHEME PACKAGE ....................... 44

TABLE 5. 4 WILLINGNESS OF HEALTH FACILITIES TO PROVIDE FAMILY PLANNING SERVICES UNDER THE NATIONAL HEALTH

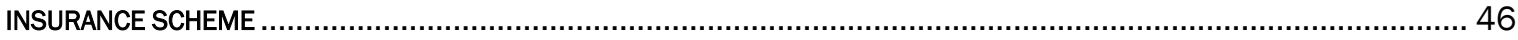

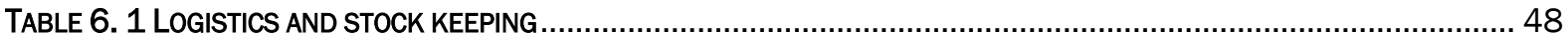

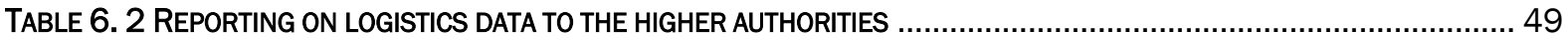

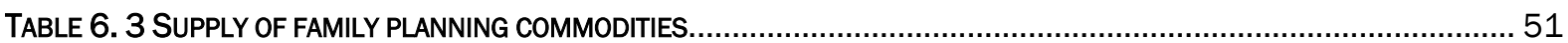

TABLE 6. 4 DETERMINATION OF RE-SUPPLY OF FAMILY PLANNING COMMODITIES ................................................... 53

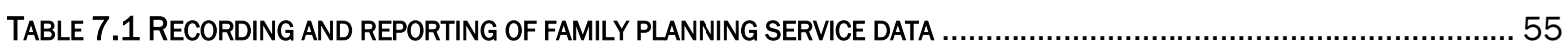

\section{LIST OF FIGURES}

FIGURE 2. 1 MAP OF THE STUDY REGIONS 


\section{LIST OF ABBREVIATIONS}

\begin{tabular}{|c|c|}
\hline CIP & Costed Implementation Plan \\
\hline CHPS & Community-Based Health Planning and Services \\
\hline CPR & Contraceptive Prevalence Rate \\
\hline DHIMS & District Health Information Management System \\
\hline FP & Family Planning \\
\hline FP-CIP & Family Planning-Costed Implementation Plan \\
\hline GDHS & Ghana Demographic and Health Survey \\
\hline GHS & Ghana Health Service \\
\hline GoG & Government of Ghana \\
\hline LARC & Long-acting Reversible Contraceptive \\
\hline LMIC & Lower Middle-Income Countries \\
\hline mCPR & Modern Contraceptive Prevalence Rate \\
\hline$M \& E$ & Monitoring and Evaluation \\
\hline $\mathrm{MOH}$ & Ministry of Health \\
\hline MSI & Marie Stopes International \\
\hline MSI-G & Marie Stopes International-Ghana \\
\hline NHIA & National Health Insurance Authority \\
\hline NHIS & National Health Insurance Scheme \\
\hline OP & Out-of-Pocket \\
\hline $\mathrm{RH}$ & Reproductive Health \\
\hline SARC & Short-acting Reversible Contraceptive \\
\hline TFR & Total Fertility Rate \\
\hline UHC & Universal Health Coverage \\
\hline WRA & Women of Reproductive Age \\
\hline
\end{tabular}




\section{PREFACE}

The Population Council in partnership with the Ministry of Health, Ghana Health Service, National Health Insurance Authority, and Marie Stopes International Ghana are pleased to present the results of the Health Facility Assessment Survey (FPNHIS) conducted in 2021. The survey focused on the availability of family planning services and readiness of health facilities for the inclusion of family planning within the National Health Insurance benefits package. The results of the FPNHIS survey will facilitate decision-making to scaleup the inclusion of family planning services into the National Health Insurance Scheme package. 


\section{EXECUTIVE SUMMARY}

\section{Background}

In Ghana, the National Health Insurance Act 852 of 2012 indicates that healthcare benefits include relevant family planning (FP) services. Although FP services are included in the health insurance Act, people continue to pay for FP services at National Health Insurance Authority credentialled health facilities because the policy is yet to be implemented in practice. Under the leadership of the Ministry of Health, the National Health Insurance Authority in collaboration with the Ghana Health Service, Marie Stopes International-Ghana and Population Council implemented a pilot project to remove FP service out-of-pocket costs. Under this pilot, all modern clinical FP methods (e.g., injectables, implants, intrauterine devices, and sterilization) were added to the national health insurance scheme and expensed by health facilities through the national health insurance claims process. Evaluation of the pilot showed that the intervention had positive impacts by significantly increasing the number of new acceptors of FP services as well as increasing the uptake of specific methods. It was also demonstrated through the pilot that FP can be included in the national health insurance benefits package without setbacks as health facilities were able to process their claims. As stakeholders consider scaling up the intervention of including FP into the national health insurance benefits package, it is important to assess the availability of FP services and readiness of health facilities for the scale-up, a void this health facility assessment seeks to fill.

\section{Objectives}

The study assessed the availability of FP services and readiness of health facilities for the inclusion of FP within the national health insurance benefits package.

\section{Methods}

This survey was part of a large research study, "Evaluating the Inclusion of FP within the National Health Insurance Benefits Package in Ghana". This study was conducted in all the 106 districts in the five FP Pilot intervention regions, Upper East, Ashanti, Central, Oti, and Volta. A cross-sectional survey design was employed to assess the availability of FP services and readiness of health facilities for the scale-up of the inclusion of FP into the NHI benefits package. The data were analyzed using Stata statistical analytic package. Univariate and bivariate analytical techniques were utilized for the data analysis.

\section{Key findings}

\section{Family Planning Services}

The study shows that 9 in 10 health facilities provide FP counseling, male condoms, oral contraceptives, injectables, implants, and emergency contraceptive methods/services. Fifty-nine percent of the health facilities have a sign on the entrance or on the exterior of the building indicating FP services are available. Ninety-seven percent of the health facilities provide FP services at least 5 days a week and 78 percent of health facilities provide FP services at least 8 hours a day. Overall, 9 in 10 of the health facilities provide adolescent-friendly health services and 68 percent of the health facilities provide post-abortion contraceptives. More than 7 in 10 health facilities (74\%) have a designated room for FP service provision. Regardless of whether a facility has a designated room for FP service provision or not, ninety-two percent of all the health facilities ensure privacy and confidentiality in the room they provide FP services. More than 9 in 10 health facilities can provide FP services to clients even if there is an increase in demand. The findings further reveal that majority of the health facilities always have 3-months injectables (95\%) and implants (90\%), and more than 80 percent of health facilities have 16 out of 26 essential FP equipment and supplies. 


\section{National Health Insurance Benefits Package}

The majority (91\%) of the health facilities provide health services under the NHIS and health facilities that are not providing health services under the NHIS attribute it to not being credentialled (66\%). In general, 79 percent of the health facilities have a staff trained in NHI claims processing. Of all the health facilities providing services under the NHIS, 7 percent provide FP services under the NHIS. In districts where the outof-pocket cost removal for FP services intervention was implemented, 58 percent of the health facilities continued providing services under the NHIS. Additionally, among health facilities currently not providing FP services under the NHIS, 94 percent are willing to provide FP services under the NHIS.

\section{Supply Chain and Logistics}

In general, 6 in 10 (60\%) health facilities have staff trained in logistics management. More than 90 percent of health facilities use stock cards/bin cards/inventory cards to manage FP commodities. Ninety-seven percent of health facilities report logistics data to a higher authority monthly. In general, 86 percent of health facilities received their commodities one month or less after requesting them. Seventy percent of health facilities determine their family planning re-supply quantities.

\section{Registry of Family Planning Service Data}

In general 96 percent of health facilities record FP service data in FP registers. Seventy-four percent of health facilities record FP service data in FP daily logbook. Almost all (98\%) health facilities report FP data using the monthly report forms. Sixty-three percent of the health facilities use the district health information management system to report family planning data.

\section{Key recommendations}

Based on the findings, the following recommendations are suggested:

- The inclusion of FP into the national health insurance scheme can be scaled up in all the districts in the five study regions as FP services are available and health facilities are ready.

- The Ghana Health Service should work toward improving commodity distribution.

- The National Health Insurance Authority should work with Ghana Health Service to credential providers who are interested in providing services under the scheme as well as address delays in credentialing.

- The National Health Insurance Authority and Ghana Health Service should work together to reach out to the FP Pilot districts to address challenges with the provision of FP within the National Health Insurance Scheme package. 


\section{INTRODUCTION}

\section{$1.1 \quad$ Background}

In Ghana, the National Health Insurance (NHI) Act was passed in 2003 (Act 650), amended in 2008 (Act 753), and revised in 2012 (Act 852). The revised Act indicates that the healthcare benefits package includes relevant family planning (FP) methods. The inclusion of FP into the NHI benefits package is expected to benefit more than 800,000 women of reproductive age who are National Health Insurance Scheme (NHIS) subscribers if the policy is operationalized ${ }^{1}$. Although FP was included in the health insurance Act, people continue to pay for FP services at National Health Insurance Authority (NHIA) credentialled health facilities because the policy is yet to be implemented in practice.

Under the leadership of the Ministry of Health (MOH), the National Health Insurance Authority (NHIA) in collaboration with the Ghana Health Service (GHS), Marie Stopes International Ghana (MSIG), and Population Council (the Council) implemented a pilot project to remove FP service out-of-pocket (OP) cost. Under this pilot, clinical FP methods (e.g., injectables, implants, intrauterine devices (IUDs), and sterilization) were added to the $\mathrm{NHI}$ benefits package and expensed by health facilities through the NHI claims process.

Findings from the FP Pilot evaluation showed that the intervention had a positive impact by significantly increasing the number of new acceptors of FP services as well as increasing uptake of specific methods ${ }^{2}$. It was also demonstrated through the pilot that FP can be included in the NHI benefits package without setbacks as health facilities were able to process their claims. As stakeholders consider scaling up the intervention of including FP into the NHI benefits package, it is important to assess the availability of FP services and readiness of health facilities for scale-up. Hence, this health facility assessment seeks to provide this information to support the scale-up process.

\subsection{The Health System Structure in Ghana}

Ghana's health sector has transformed over the years and the goal of these changes have been to improve the health outcomes of the population, offer financial protection, and ensure that Ghana's health system is more responsive, efficient, equitable, and sustainable to achieve universal health coverage (UHC). The hierarchical structure of Ghana's health system comprises the $\mathrm{MOH}$, which is the overarching body that oversees the overall health system in the country. $\mathrm{MOH}$ is the body responsible for health policy formulation, resource mobilization, monitoring, and regulation of delivery of health care by different agencies ${ }^{3}$. GHS is an agency under the $\mathrm{MOH}$ and primarily administrates the health services provided by the government and implements government policies on healthcare. GHS is also responsible for public health service delivery by hospitals, quasi-government health facilities at the regional, district, and community levels. Secondary level health care is provided by regional and district hospitals, while health centers and Community-based Health Planning and Services (CHPS) provide basic preventive and curative health care at the community level. Tertiary level health facilities which are agencies under the $\mathrm{MOH}$ provide specialty health care services. However, GHS does not include private and faith-based Hospitals. Regardless of the type of health facility, FP services are provided at all levels of the GHS system structure as well as in teaching hospitals, and some private and faith-based health facilities.

\subsection{National Health Insurance Scheme}

The National Health Insurance Scheme (NHIS) is a social intervention program introduced by the Government of Ghana (GOG) to provide financial access to quality healthcare for residents in Ghana. NHIA credentials

\footnotetext{
1FP2020. www.familyplanning2020.org/resources/advocacy-country-spotlight-ghana. Accessed on $1^{\text {st }}$ June 2020.

2 Fuseini, K. \& Ankomah, A. 2020. "Evaluating the inclusion of family planning within the National Health Insurance benefits package in Ghana," Research Report. Washington, DC: Population Council.

3 Mills, A., Ally, M., Goudge, J., Gyapong, J., \& Mtei, G. (2012). Progress towards universal coverage: The health systems of Ghana, South Africa and Tanzania. Health Policy and Planning, 27(SUPPL.1), 4-12. https://doi.org/10.1093/heapol/czs002
} 
both public and private health facilities to provide services under the NHIS and this has broadened access to health services ${ }^{4}$.

Core principles: The mission of the National Health Insurance Authority is to provide financial risk protection against the cost of quality, basic health care for all residents in Ghana. To ensure the sanctity of its mission, the scheme is built around five core principles, integrity, accountability, empathy, responsiveness, and innovation.

Funding: The scheme is largely funded by the National Health Insurance Levy (NHIL) which is a 2.5 percent levy on goods and services collected under the Value Added Tax (VAT). It is also funded by a 2.5 percentage point of employees' Social Security and National Insurance Trust (SSNIT) contributions per month, a return on National Health Insurance Fund (NHIF) investments, and a premium paid by informal sector subscribers.

Exemption: NHIS subscribers fall into two broad groups, the informal and exempt groups. It is only the informal group that pays a premium. Members of the exempt group are formal sector employees and the self-employed who contribute to SSNIT. Children (persons under 18 years of age), adults 70 years and above, persons with mental disorders, pregnant women, and persons classified by the Minister of Social Welfare as indigent are exempted from paying annual premiums.

Benefits package: The minimum benefits package under the NHIS includes general out-patient and inpatient care, oral health, eye care, comprehensive delivery care, diagnostic tests, generic medicines, and emergency care. In all, over $95 \%$ of the most common disease conditions reported in healthcare facilities in Ghana are covered under the scheme. Highly specialized care such as dialysis for chronic renal failure, organ transplants and services provided under government vertical programs (e.g., antiretroviral for the treatment of HIV/AIDS and immunization, and family planning), and drugs not listed in the NHIS drug list are not covered $^{5}$.

Membership coverage: To access healthcare under the NHIS, the NHI regulations, L.I. 1809, requires an individual or group of persons to visit a designated NHIA registration point(s) to register and or renew their registration (activate policy) to warrant use of healthcare services covered under the NHIS package. Renewals of registration can be completed via mobile phone with the short code $* 929 \#$. The scheme as of December 2020 has total coverage of 52 percent of the total population.

Credentialling of providers: To provide the basic package of services, the NHIS Quality Assurance Directorate assesses and evaluates the capacity and capabilities to provide the set of benefits packages. The following modules are applied to health facilities, including human resources (cadre of health personnel), environment (serenity and conducive nature), and diagnostics (available equipment and health machinery). The assessment criteria ensure that credentialed health facilities have the requirements to provide the essential quality services expected. The scheme credentials both public and private (including faith-based) health care providers at all levels of the health system subject to an assessment outcome. As of December 2020, the total number of credentialed health facilities was about 4,100 facilities. This includes hospitals and clinics, maternity homes, pharmacies, licensed chemical shops, and diagnostic facilities.

Provider payment mechanisms: The NHIS Act 852 prescribes a fee for service, diagnostic related groupings, capitation, and any other payment mechanism that the Board in consultation with healthcare providers and the Minister may determine. Currently, the NHIS reimburses its credentialed facilities with two payment methods namely "Fee for Service" and "Ghana-Diagnostic Related Groupings". Medicines are reimbursed using fee for service (itemized billing), a payment mechanism in which a provider is paid for individual service rendered to a patient, whilst services are reimbursed using Ghana Diagnosis Related Groupings (G-DRG), a payment mechanism where clinically similar diseases that have comparable treatments or operations and use similar healthcare resources are grouped.

\footnotetext{
${ }^{4}$ Saleh, K. (2013). The health sector in Ghana: A comprehensive assessment. The World Bank.

${ }^{5}$ Gobah, F. K., \& Zhang, L. (2011). The National Health Insurance Scheme in Ghana: Prospects and Challenges: a cross-sectional evidence. Global Journal of Health Science, 3(2), 90-101. https://doi.org/10.5539/gjhs.v3n2p90
} 


\subsection{Pilot Inclusion of Family Planning into the National Health Insurance Scheme}

The pilot inclusion of FP into the NHIS (referred to as FP Pilot) started in May 2018 to include all clinical FP methods (e.g., injectables, implants, IUDs, sterilization) into the NHI benefits package and expensed by health facilities through the claims process. The FP Pilot intervention was implemented in selected districts in the Central region (Mfantsiman, Ekumfi, Upper Denkyira East and Upper Denkyira West), Volta region 6 (Adaklu), Ashanti region (Obuasi), and Upper East region (Bolgatanga, Nabdam, and Bawku West). The intervention was implemented in public and private NHIA-credentialled health facilities across the nine districts $^{7}$. Five different combinations of three interventions-OP cost removal for FP services, demand generation, and provider training on long-acting reversible contraceptive (LARC) service delivery-were implemented in the nine districts.

\subsection{Study Objective}

Broadly, the study assessed the availability of FP services and readiness of health facilities for the inclusion of FP within the NHI benefits package. Specifically, the study assessed:

i. Family planning service availability - the physical presence of the delivery of services, including the infrastructure, provision of health services with specific reference to FP services under the NHI benefits package, and FP providers at the health facility level.

ii. Readiness of health facilities for FP service provision - the ability of health facilities to offer FP services and the capacity to provide FP services (i.e., including trained staff, service delivery guidelines, equipment, diagnostic capacity, and commodities).

\subsection{Structure of the Report}

The report is structured into eight chapters. The introductory section (Chapter one) provides background information on the study, the health system structure of Ghana, the national health insurance scheme, and the pilot inclusion of FP into the NHIS. The chapter also outlines the aims and objectives of the study. The methods section (Chapter two) describes the setting of the study, the study design employed, the procedures used in selecting the sample (health facilities), the survey tool, recruitment of data collectors, training, fieldwork, quality assurance, data processing, statistical analysis, and ethical considerations. Chapter three presents the background characteristics of the health facilities surveyed and Chapter four presents the findings on FP services including availability and provision of FP methods/services as well as FP service readiness. Chapter five is on the NHIS package which outlines the provision of health services under the NHIS, training on NHIS claims, and provision of FP within the NHIS package. Chapter six presents the supply chain and logistics which consists of findings on FP commodity stock keeping, supply, and logistics, reporting logistics data to the higher authorities, and supply of FP commodities. Chapter seven is on the registry of FP service data, which outlines the recording and reporting of FP service data. The conclusions and recommendations of the study are presented in Chapter eight.

\footnotetext{
${ }^{6}$ At the time the project started Oti and Volta regions were one region

7 The project included 10 districts, however, there was no intervention in the $10^{\text {th }}$ district (Mamprusi West)
} 


\section{METHODOLOGY}

The inclusion of FP into the national health insurance survey (FPNHIS) was part of a larger research study, "Evaluating the Inclusion of FP within the NHI Benefits Package in Ghana". This research study was a followon to the "Pilot Inclusion of Family Planning Services on the National Health Insurance Benefits Package" project.

\subsection{Study Setting}

The study was conducted in all 106 districts in the five FP Pilot intervention regions, Upper East, Ashanti, Central, Oti, and Volta ${ }^{8}$ (see Figure 2.1). Table 2.1 presents the characteristics of the study regions. The Ashanti region is the largest with a population of 5,924,498 and 43 administrative districts. The least populated region is Oti with a population of 759,799 and 8 administrative districts. 
Table 2. 1 Characteristics of study regions

\begin{tabular}{|c|c|c|c|c|c|c|c|c|c|}
\hline \multirow[b]{2}{*}{ Region } & \multicolumn{5}{|c|}{2020 projected Population } & \multirow[b]{2}{*}{$\begin{array}{l}\text { GFR } \\
\text { (per } 1000 \\
\text { women, 15- } \\
49 \text { years) }\end{array}$} & \multirow[b]{2}{*}{${ }^{x}$ TFR } & \multirow[b]{2}{*}{$\begin{array}{l}{ }^{t} \text { Knowledge of } \\
\text { any modern } \\
\text { Contraceptive } \\
\text { method }\end{array}$} & \multirow[b]{2}{*}{$\begin{array}{l}{ }^{\dagger} \text { Use of any modern } \\
\text { Contraceptive method }\end{array}$} \\
\hline & $\begin{array}{l}\text { Number } \\
\text { of } \\
\text { Districts }\end{array}$ & $\begin{array}{l}\text { Total } \\
\text { Population }\end{array}$ & $\begin{array}{l}\% \text { of the total } \\
\text { population of } \\
\text { the country }\end{array}$ & Males & Females & & & & \\
\hline Ashanti & 43 & $5,924,498$ & 19.1 & $2,915,061$ & $3,009,437$ & 96.4 & 3.8 & 100 & 20.8 \\
\hline Central & 22 & $2,605,492$ & 8.4 & $1,281,998$ & $1,323,494$ & 105.3 & 4.3 & 100 & 27.5 \\
\hline Upper East & 15 & $1,302,718$ & 4.2 & 640,981 & 661,737 & 97.5 & 4.7 & 99 & 23.3 \\
\hline Volta & 18 & $1,907,679$ & 6.2 & 938,602 & 969,077 & 99.2 & 4.1 & 100 & 29.5 \\
\hline Oti & 8 & 759,799 & 2.5 & 373,894 & 385,905 & & & & \\
\hline Sub-Total & 106 & $12,500,186$ & & $6,150,536$ & $6,349,650$ & & & & \\
\hline $\begin{array}{l}\text { Projected } \\
\text { national } \\
\text { population }\end{array}$ & & $30,955,204$ & & & & & & & \\
\hline
\end{tabular}

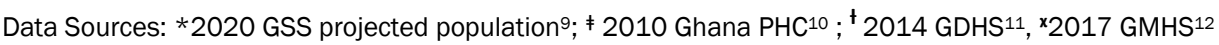

Note: Oti region was created out of Volta region in 2018; GFR is general fertility rate; TFR is total fertility rate 
Figure 2. 1 Map of the study regions

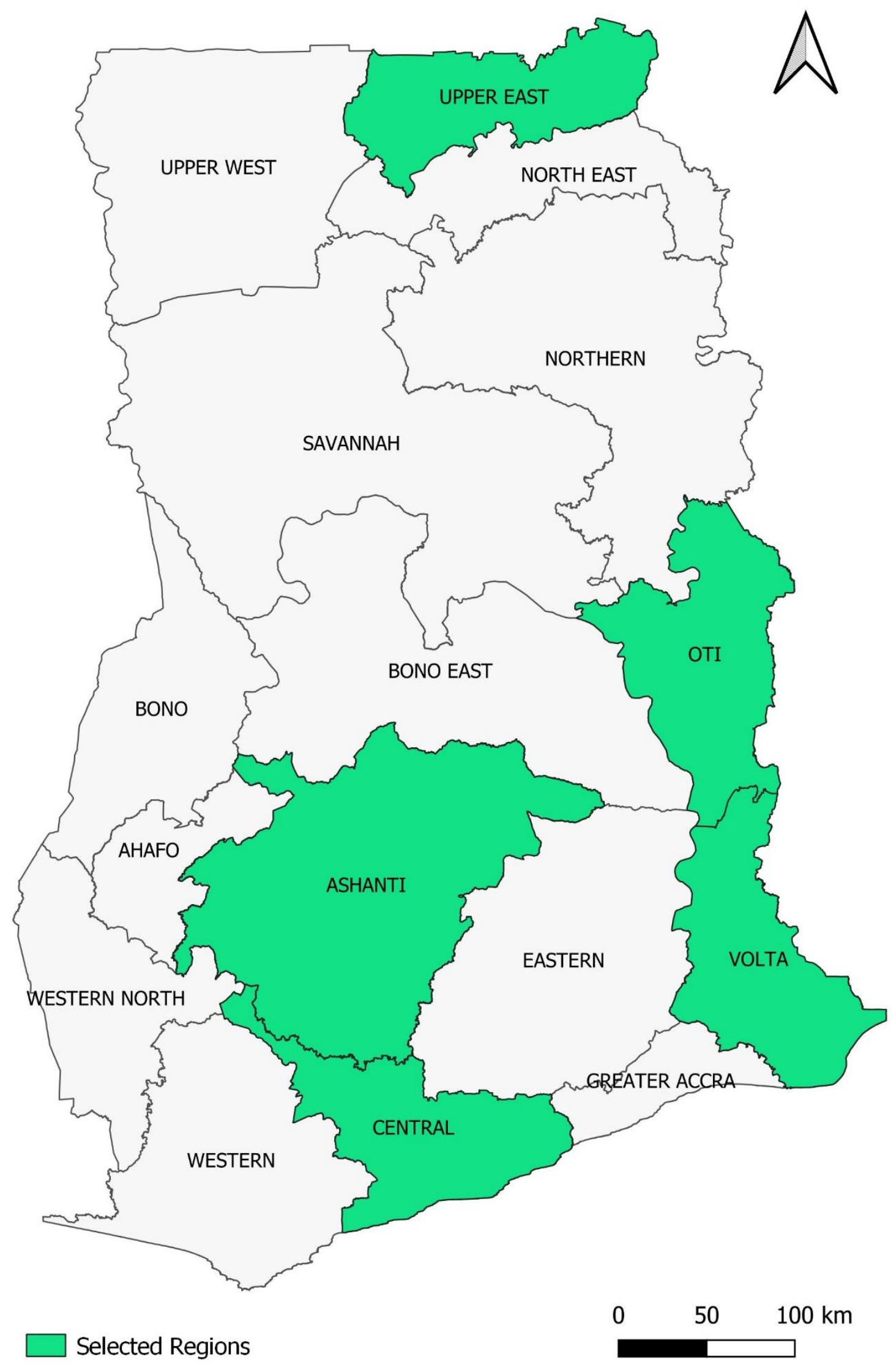




\subsection{Design}

A cross-sectional survey design was employed to assess the availability of FP services and readiness of health facilities for the scale-up of the inclusion of FP into the NHI benefits package.

\subsection{Sample}

A sample of health facilities providing FP was randomly drawn from a stratified list of private and public health facilities in the five study regions provided by the Family Health Division of Ghana Health Service. The sample of 623 health facilities was distributed by region proportionate to the number and level of health facilities, the proportion of rural-urban health facilities, and managing authority of health facilities (see the detailed description of sample size calculation in Appendix 2). A total of 623 health facilities providing FP services were randomly selected and interviewed. However, information from two health facilities was dropped due to missing data. Hence the analytical sample for this report is 621 health facilities providing FP services.

\subsection{Questionnaire}

The health facility assessment questionnaire was adapted from the Harmonized Health Facility Assessment (HHFA) tool by the World Health Organization (WHO) ${ }^{13}$. The HHFA is a standardized health facility assessment tool that integrates other facility assessment tools, including the Service Availability and Readiness Assessment (SARA) tool jointly developed by ICF International under the United States Agency for International Development (USAID)-funded Demographic and Health Surveys and the World Health Organization (WHO) ${ }^{14}$. Service Provision Assessment (SPA) tools from which the HHFA questionnaire was derived have generally been used particularly in low- and middle-income settings to generate health service delivery data ${ }^{15}$. The health facility assessment questionnaire was reviewed and revised by a team of representatives from the $\mathrm{MOH}$, GHS, NHIA, MSIG, and the Council. The team also discussed and agreed on data collection strategies taking into consideration the risks of the COVID-19 pandemic. A detailed COVID19 risk mitigation plan was also developed to guide fieldwork.

The questionnaire (Appendix 3) comprised of information on the characteristics of the health facilities, availability of FP services (including the provision of general health and FP services under the NHIS), availability of FP commodities, supply chain and logistics, essential FP equipment, and supplies, staff volumes (including staff trained to provide FP services), activities performed by staff, training, and registry verification of method volumes.

A Computer-Assisted Personal Interview (CAPI) was used for the data collection and the programming was done using the Census and Survey Processing System (CSPro). The program was deployed through android supported phones and tablets for data collection.

\subsection{Recruitment of Data Collectors}

Data collectors were recruited from a pool of experienced data collectors who were part of a similar health facility-level national survey on maternal health (including family planning). Selected supervisors of the previous fieldwork were requested to recommend highly skilled data collectors who had performed exceptionally well in the survey. The nominated candidates were interviewed to assess their availability, field

\footnotetext{
${ }^{13}$ World Health Organization. (2021). Harmonized health facility assessment (HHFA): combined questionnaire. https://www.who.int/data/data-collectiontools/harmonized-health-facility-assessment/introduction

14 World Health Organization (WHO). (2013). Service Availability and Readiness Assessment (SARA): An annual monitoring system for service delivery

Reference Manual. http://www.who.int/about/licensing/copyright_form/en/index.html

15 Sheffel, A., Karp, C., \& Creanga, A. A. (2018). Use of Service Provision Assessments and Service Availability and Readiness Assessments for monitoring quality of maternal and newborn health services in low-income and middle-income countries. BMJ Global Health, 3(6), 1-9.

https://doi.org/10.1136/bmjgh-2018-001011
} 
experience, knowledge of the geography of the study area as well as their knowledge about family planning after which 34 out of 40 were selected.

\subsection{Training of Data Collectors}

The health facility assessment training was facilitated by GHS and the Council with support from the $\mathrm{MOH}$, NHIA, and MSIG on $18^{\text {th }}$ May 2021. The one-day virtual training conducted via Zoom involved, standard human research ethics, recruitment of health facilities, and data collection. The training covered topics on the background of the survey, the role of interviewers, survey regulations and timelines, ethics, sample description, respondent's eligibility criteria, and a question-by-question review. The training ensured that data collectors understood the data collection instrument and equipped them with the skills required to collect quality data.

To ensure smooth virtual training, data collectors were provided with information on the survey including the questionnaire to review one week before the training. Data collectors were also provided with mobile data bundles for the training and where necessary they were provided money for transportation to travel to a place with a reliable internet connection to facilitate maximum participation. All data collectors were reimbursed for lunch. To ensure that data collectors were fully engaged throughout the training, tests were administered intermittently during and at the end of training for each section. Each participant was required to respond, and the results of the tests were reviewed. Challenges identified with responses to the questions were discussed for a common general understanding.

Data collectors were also trained on using android devices to collect data (all data collectors had prior experience in CAPI). They were assisted to install the CSPro data entry software application on android phones or tablets. All data collectors were required to enter trial data into the system. After the trial data entry, the research team reached out to data collectors to assist with challenges they faced during the trial.

A WhatsApp platform was created for constant communication between data collectors, supervisors, and principal investigators. A dedicated telephone number was also provided to data collectors to enable them to keep in touch with supervisors. Data collectors were also provided with telephone airtime to facilitate communication.

Supervisors were trained separately on all the content used for the training of data collectors as well as how to supervise data collectors and provide quality control on the data collected by data collectors. The training also covered the daily reporting process to Population Council staff.

\section{$2.7 \quad$ Fieldwork}

Before the start of fieldwork, letters of introduction from GHS (at the national level) were sent to the various regional health directorates and they relayed the information to the district health directorates and they, in turn, informed health facilities in the districts about the survey.

Fieldwork began on 24th May 2021 and ended on 20th June 2021. The unit of analysis is the health facility, hence there was one questionnaire for each health facility. The questionnaire was addressed to the in-charge of the health facility, or a designated individual(s) who was/were knowledgeable about the health facility and FP services in the health facility. The in-charge or health facility designee was informed about the structure of the questionnaire and that the questionnaire could be completed over more than one visit (more than one staff member from a health facility could respond to the questionnaire based on who had specific information).

Interviews were conducted face-to-face adhering to the GHS Ethics Review Committee's approved COVID-19 protocols and national guidelines. Before the interviews, oral permission was obtained from the health facility in charge. At the health facilities, data collectors recorded responses to questions on the CAPI instruments. Where health facilities were no longer operational or did not provide FP services, the facilities were replaced. 


\subsection{Quality Control}

Population Council staff coordinated the fieldwork. The quality of data collected was monitored throughout the fieldwork, internal checks were built into the CSPro data capture system to address data inconsistencies and errors. Data collectors were required to take the Global Positioning System (GPS) coordinates of health facilities assessed and meta data analysis was conducted for verification. Monitoring teams made up of GHS and the Council staff also visited randomly selected health facilities in all the regions to validate responses. Throughout the data collection period, the data management team continuously reviewed the data collected to check for errors and inconsistencies as well as the performance of each research assistant. Data collectors were contacted on daily basis for updates and regularly provided with feedback on inconsistencies, errors, and missing data. Descriptive tables from the data were also reviewed thoroughly for inconsistencies. Where necessary, data collectors were required to go back to the health facility to verify and resolve the error or inconsistency.

\subsection{Data Processing}

CSPro, a software tool for census and survey data, which supports CAPI data entry, was used to collect, inspect, and edit the data. This aided in improving data quality and efficient interviewing as it determined the question order, skip patterns allowed for consistency checks thus minimizing interviewer errors. After completion of interviews, the data were checked for completeness, consistency, and accuracy and subsequently exported from CSPro to Stata for analysis.

\subsection{Statistical Analysis}

The data were analyzed using Stata (version 17) statistical analytic package. Univariate (e.g., frequencies, means) and bivariate (cross-tabulations) analytical techniques were utilized for the data analysis. The data analysis focused mainly on the FP service availability and readiness of health facilities to provide FP services under the national health insurance benefits package.

\subsection{Ethics}

Ethics approval was obtained from the Ghana Health Service Ethics Review Committee and the Population Council Institutional Review Board. The purpose of the study and study requirements were explained to incharges at the health facilities and other respondents in the study facilities to obtain oral consent before the start of the interview. Respondents were assured of confidentiality. 


\section{BACKGROUND CHARACTERISTICS}

This chapter provides an overview of the characteristics of the health facilities surveyed, including information on the type of health facility, location, managing authority, region, and whether the health facility is in an FP Pilot intervention district or not. These analyses serve as the basis for understanding the status of health facilities.

\subsection{Characteristics of Health}

\section{Facilities}

The analytical sample for this report is 621 health facilities providing FP services from 106 districts in the five study regions. Type, location, region, managing authority of health facilities, and study site are the characteristics of the health facilities considered.

Table 3.1 shows the percentage distribution of the health facilities by background characteristics. The highest proportion of the health facilities are community-based health planning services (48\%) followed by health centers (35\%), hospitals (13\%), and the least are maternity homes (3\%).

Seven in ten $(70 \%)$ health facilities are in rural areas and the majority of health facilities $(86 \%)$ are managed by the government with the least proportion of health facilities being managed by mission/faith-based organizations (3\%).

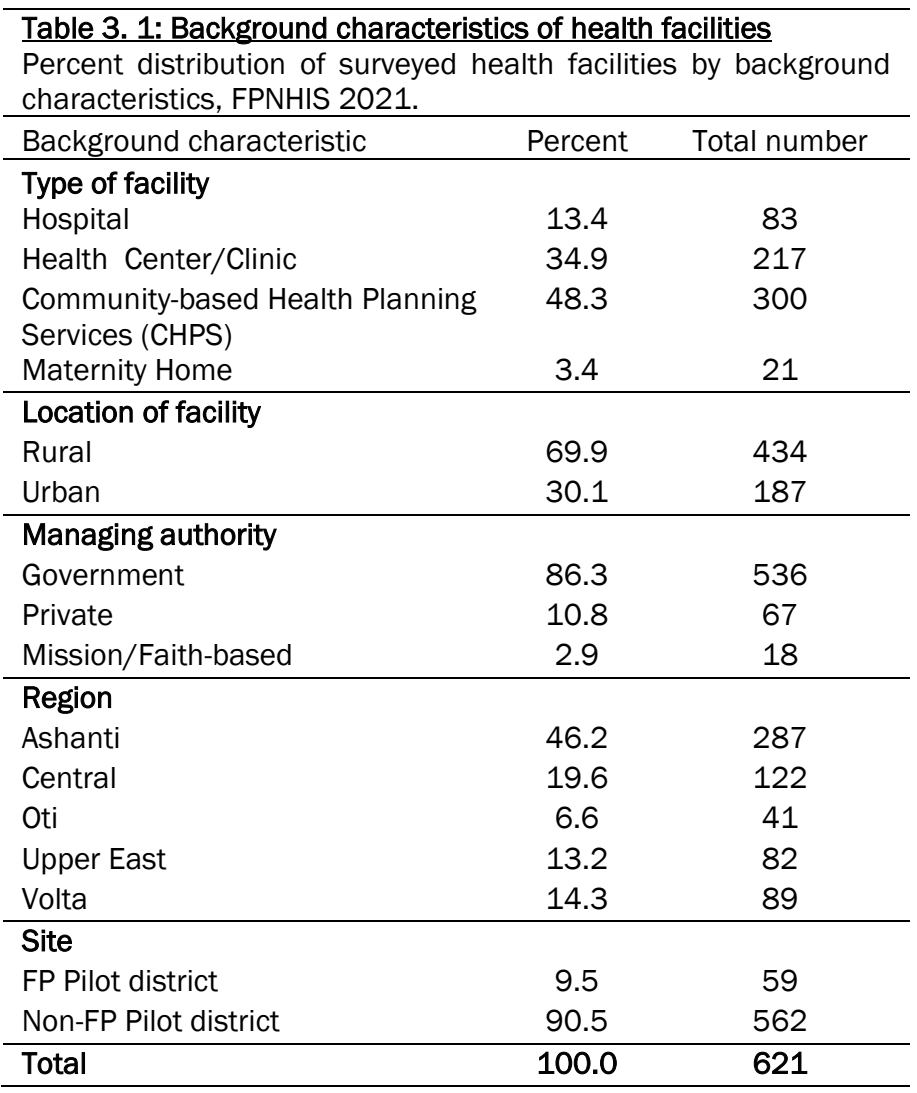

The highest percent of the health facilities are in the Ashanti region (46\%) followed by Central region (20\%), and the least in the Oti region (7\%). About 9 in 10 (91\%) of the health facilities are in the non-FP pilot districts. 


\section{FAMILY PLANNING SERVICES}

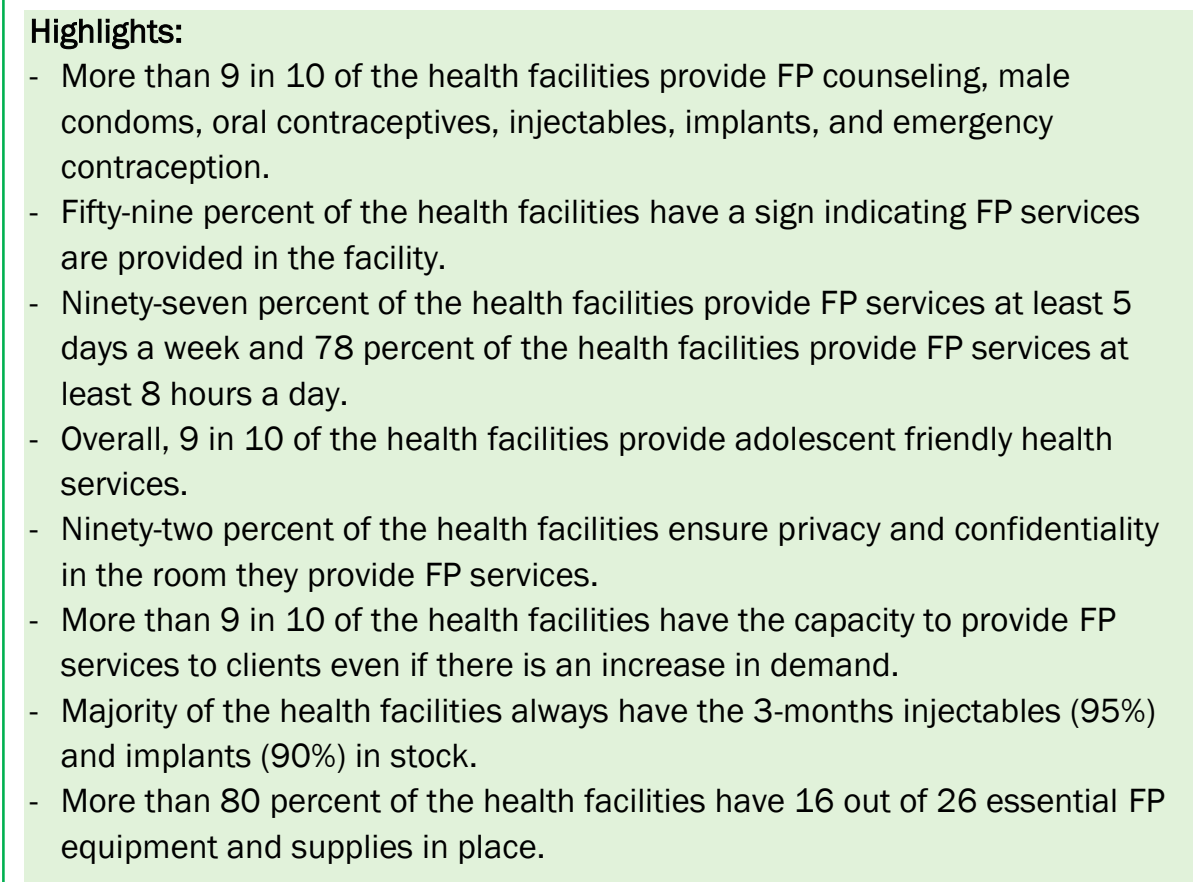

This study was designed to assess FP services in health facilities in the five study regions. This chapter presents information on the availability of FP services, provision of FP services, and FP service readiness. These topics are important to policymakers as the country prepares to scale-up the inclusion of FP into the NHIS package.

\subsection{Availability of Family Planning Services}

Availability of FP services (and method mix) are important for the uptake and use of FP services. The FPNHIS collected information on the availability of FP services by asking about the types of modern FP method(s)/service(s) provided at the health facility. Selected health facilities responded to 11 questions on FP services (counseling, male condom, female condom, oral contraceptives, injectables, implants, IUD, female sterilization, male sterilization, emergency contraceptives, and natural methods (e.g., cycle beads for standard days method)).

\subsubsection{Family Planning Methods/Services Provided}

Table 4.1 shows the percentage distribution of health facilities providing different FP method(s)/service(s). The provision of FP counseling services is almost universal (98\%). The most common FP methods provided are injectables (99\%), emergency contraceptives (98\%), implants (96\%), oral contraceptives (93\%), and male condoms (91\%) while the least provided service is male sterilization (8\%).

Levels of FP counseling, as well as the percentage of health facilities providing implants and emergency contraception methods/service provision, do not differ much across the different types of health facilities, rural and urban areas, regions, and by site. However, there are substantial variations in the provision of IUD. Only a little more than a third (35\%) of the health facilities provide IUD services which vary across background characteristics. At least 90 percent of the health facilities provide male condoms, oral contraceptives, injectables, implants, and emergency contraceptives. 


\begin{tabular}{|c|c|c|c|c|c|c|c|c|c|c|c|c|}
\hline & Counseling & $\begin{array}{c}\text { Male } \\
\text { condom }\end{array}$ & $\begin{array}{c}\text { Female } \\
\text { condom }\end{array}$ & $\begin{array}{c}\text { Oral } \\
\text { contraceptives }\end{array}$ & Injectables & Implants & IUD & $\begin{array}{c}\text { Female } \\
\text { sterilization }\end{array}$ & $\begin{array}{c}\text { Male } \\
\text { sterilization }\end{array}$ & $\begin{array}{c}\text { Emergency } \\
\text { contraception }\end{array}$ & $\begin{array}{l}\text { Natural } \\
\text { methods }\end{array}$ & $\begin{array}{c}\text { Total } \\
\text { Number }\end{array}$ \\
\hline \multicolumn{13}{|l|}{ Type of Facility } \\
\hline Hospital & 96.4 & 86.7 & 61.4 & 85.5 & 95.2 & 90.4 & 69.9 & 62.7 & 43.4 & 96.4 & 63.9 & 83 \\
\hline Health Center/Clinic & 98.2 & 92.6 & 48.8 & 96.8 & 98.6 & 97.7 & 43.8 & 7.4 & 4.6 & 98.2 & 59.0 & 217 \\
\hline Community-based Health & 98.7 & 93.0 & 51.3 & 93.7 & 99.3 & 96.7 & 16.0 & 0.0 & 0.0 & 98.7 & 58.0 & 300 \\
\hline \multicolumn{13}{|l|}{ Planning Services (CHPS) } \\
\hline Maternity Home & 100.0 & 66.7 & 38.1 & 71.4 & 100.0 & 81.0 & 66.7 & 9.5 & 4.8 & 100.0 & 42.9 & 21 \\
\hline \multicolumn{13}{|l|}{ Location of facility } \\
\hline Rural & 98.2 & 94.2 & 51.6 & 95.2 & 99.1 & 97.5 & 26.3 & 4.6 & 3.5 & 98.2 & 59.4 & 434 \\
\hline Urban & 98.4 & 84.0 & 50.8 & 87.7 & 97.3 & 91.4 & 54.0 & 26.7 & 17.1 & 98.4 & 56.7 & 187 \\
\hline \multicolumn{13}{|l|}{ Managing authority } \\
\hline Government & 98.5 & 94.0 & 53.4 & 95.7 & 99.3 & 97.6 & 32.8 & 8.4 & 6.7 & 98.5 & 61.8 & 536 \\
\hline Private & 95.5 & 68.7 & 35.8 & 73.1 & 95.5 & 82.1 & 52.2 & 32.8 & 13.4 & 97.0 & 34.3 & 67 \\
\hline Mission/Faith-based & 100.0 & 88.9 & 50.0 & 83.3 & 88.9 & 88.9 & 22.2 & 16.7 & 11.1 & 94.4 & 55.6 & 18 \\
\hline \multicolumn{13}{|l|}{ Region } \\
\hline Ashanti & 97.2 & 85.4 & 40.8 & 91.3 & 97.2 & 93.4 & 34.8 & 16.0 & 10.5 & 97.2 & 42.9 & 287 \\
\hline Central & 100.0 & 93.4 & 62.3 & 92.6 & 100.0 & 96.7 & 47.5 & 9.8 & 8.2 & 100.0 & 73.8 & 122 \\
\hline Oti & 100.0 & 100.0 & 75.6 & 100.0 & 100.0 & 100.0 & 39.0 & 9.8 & 2.4 & 100.0 & 80.5 & 41 \\
\hline Upper East & 97.6 & 98.8 & 57.3 & 91.5 & 98.8 & 95.1 & 20.7 & 3.7 & 2.4 & 97.6 & 67.1 & 82 \\
\hline Volta & 98.9 & 95.5 & 53.9 & 96.6 & 100.0 & 100.0 & 27.0 & 5.6 & 4.5 & 98.9 & 70.8 & 89 \\
\hline \multicolumn{13}{|l|}{ Site } \\
\hline FP Pilot district & 100.0 & 93.2 & 61.0 & 93.2 & 100.0 & 96.6 & 39.0 & 8.5 & 6.8 & 100.0 & 69.5 & 59 \\
\hline Non-FP Pilot district & 98.0 & 90.9 & 50.4 & 92.9 & 98.4 & 95.6 & 34.2 & 11.6 & 7.7 & 98.0 & 57.5 & 562 \\
\hline Total & 610 & 566 & 319 & 577 & 612 & 594 & 215 & 70 & 47 & 610 & 364 & 621 \\
\hline Percent & 98.2 & 91.1 & 51.4 & 92.9 & 98.6 & 95.7 & 34.6 & 11.3 & 7.6 & 98.2 & 58.6 & 100.0 \\
\hline
\end{tabular}




\subsubsection{Availability of a Sign Indicating the Provision of Family Planning Services and Frequency of Availability of Family Planning Service}

The availability of FP methods or services is as important as clients knowing they are available. Table 4.2 provides information on health facilities having a sign at the entrance or the exterior of the building indicating that FP services are available. Information on the number of days in a week that FP services are provided, and the number of hours per day FP services are provided were obtained.

Overall, about 59 percent of the health facilities have a sign at the entrance or exterior of their buildings indicating FP services are available. The highest proportion of health facilities that have a sign at the entrance, or on the exterior of their buildings indicating FP services are available are maternity homes (81\%), followed by hospitals (69\%), health centers/clinics $(66 \%)$, and the least are community-based health planning services (48\%). Further, the highest percentage of health facilities that have signs at the entrance or on the exterior of their buildings are in the Central region (87\%), FP pilot districts (68\%), urban areas (67\%), and are mostly private health facilities (63\%).

Among all the health facilities, a little more than half (53\%) provide FP services more than five days a week, $45 \%$ provide FP services five days a week and only 3 percent provide FP services less than five days a week. At least 90 percent of all the health facilities provide FP services at least five days a week.

Less than half (46\%) of the health facilities provide FP services for more than eight hours a day, which is the highest, followed by 32 percent providing FP services for eight hours a day and about a fifth (23\%) providing FP services for less than eight hours a day. In general, 78 percent of the health facilities provide FP services for at least eight hours a day. 


\begin{tabular}{|c|c|c|c|c|c|c|c|c|}
\hline+2 & \multirow{2}{*}{$\begin{array}{l}\text { Have a sign } \\
\text { indicating FP } \\
\text { services are } \\
\text { available }\end{array}$} & \multicolumn{3}{|c|}{$\begin{array}{l}\text { Number of days per } \\
\text { week FP services } \\
\text { are provided: }\end{array}$} & \multicolumn{3}{|c|}{$\begin{array}{c}\text { Number of hours per } \\
\text { day FP services are } \\
\text { provided: }\end{array}$} & \multirow[b]{2}{*}{$\begin{array}{c}\text { Total } \\
\text { number }\end{array}$} \\
\hline & & $\begin{array}{c}<5 \\
\text { days }\end{array}$ & $\begin{array}{c}5 \\
\text { days }\end{array}$ & $\begin{array}{l}>5 \\
\text { days }\end{array}$ & $\begin{array}{l}<8 \\
\text { hours }\end{array}$ & $\begin{array}{c}8 \\
\text { hours }\end{array}$ & $\begin{array}{c}>8 \\
\text { hours }\end{array}$ & \\
\hline \multicolumn{9}{|l|}{ Type of Facility } \\
\hline Hospital & 68.7 & 1.2 & 62.7 & 36.1 & 19.3 & 43.4 & 37.3 & 83 \\
\hline Health Center/Clinic & 66.4 & 2.3 & 52.1 & 45.6 & 18.0 & 44.2 & 37.8 & 217 \\
\hline $\begin{array}{l}\text { Community-based Health } \\
\text { Planning Services (CHPS) }\end{array}$ & 48.3 & 3.7 & 37.3 & 59.0 & 27.0 & 20.3 & 52.7 & 300 \\
\hline Maternity Home & 81.0 & 4.8 & 0.0 & 95.2 & 19.0 & 14.3 & 66.7 & 21 \\
\hline \multicolumn{9}{|l|}{ Location of facility } \\
\hline Rural & 54.6 & 3.5 & 41.5 & 55.1 & 25.6 & 28.8 & 45.6 & 434 \\
\hline Urban & 67.4 & 1.6 & 51.9 & 46.5 & 15.5 & 38.0 & 46.5 & 187 \\
\hline \multicolumn{9}{|l|}{ Managing Authority } \\
\hline Government & 58.2 & 2.6 & 45.5 & 51.9 & 22.8 & 31.9 & 45.3 & 536 \\
\hline Private & 62.7 & 6.0 & 32.8 & 61.2 & 22.4 & 23.9 & 53.7 & 67 \\
\hline Mission/Faith-based & 50.0 & 0.0 & 61.1 & 38.9 & 16.7 & 50.0 & 33.3 & 18 \\
\hline \multicolumn{9}{|l|}{ Region } \\
\hline Ashanti & 56.4 & 2.1 & 48.8 & 49.1 & 22.0 & 34.5 & 43.6 & 287 \\
\hline Central & 86.9 & 1.6 & 44.3 & 54.1 & 9.8 & 35.2 & 54.9 & 122 \\
\hline Oti & 48.8 & 7.3 & 36.6 & 56.1 & 68.3 & 14.6 & 17.1 & 41 \\
\hline Upper East & 50.0 & 4.9 & 30.5 & 64.6 & 29.3 & 9.8 & 61.0 & 82 \\
\hline Volta & 38.2 & 3.4 & 48.3 & 48.3 & 14.6 & 44.9 & 40.4 & 89 \\
\hline \multicolumn{9}{|l|}{ Site } \\
\hline FP Pilot district & 67.8 & 3.4 & 23.7 & 72.9 & 27.1 & 25.4 & 47.5 & 59 \\
\hline Non-FP Pilot district & 57.5 & 2.8 & 46.8 & 50.4 & 22.1 & 32.2 & 45.7 & 562 \\
\hline Total & 363 & 18 & 277 & 326 & 140 & 196 & 285 & 621 \\
\hline Percent & 58.5 & 2.9 & 44.6 & 52.5 & 22.5 & 31.6 & 45.9 & 100.0 \\
\hline
\end{tabular}

Analysis of the availability of FP services to adolescents and post-abortion care by background characteristics is important for issues of equity of family service provision especially as it relates to the inclusion of FP into the NHI benefits package. Table 4.3 presents the percentage distribution of health facilities that offer adolescent-friendly FP services and the proportion providing contraceptives post-abortion by background characteristics.

Overall, nearly 9 in 10 (89\%) of the health facilities provide adolescent-friendly FP services. Majority of community-based health planning services (91\%) and maternity homes (91\%) provide adolescent-friendly FP services. Similarly, over 90 percent of health facilities located in the rural areas, Central and Oti regions, FP Pilot districts, and government facilities provide adolescent-friendly FP services.

On post-abortion care provision of contraceptives, 68 percent of health facilities provide post-abortion contraception to clients. By type of health facility, about 9 in 10 hospitals (90\%) provide post-abortion contraceptives, a little more than half of community-based health planning services (55\%) do. The data further shows that health facilities in urban areas are more likely to provide post-abortion contraception compared with rural health facilities ( $82 \%$ versus $62 \%$ ). By managing authority, the percentage of private health facilities providing post-abortion care contraceptives is higher (82\%) relative to mission/faith-based $(67 \%)$ and government (66\%) facilities. More than 7 in 10 health facilities are located in the Central region and more than two-thirds $(68 \%)$ of health facilities in non-FP Pilot districts provide post-abortion contraception to clients. 


\begin{tabular}{|c|c|c|c|}
\hline & $\begin{array}{c}\text { Provide adolescent-friendly } \\
\text { FP services }\end{array}$ & $\begin{array}{c}\text { Provide } \\
\text { post-abortion care } \\
\text { contraceptives }\end{array}$ & Total number \\
\hline \multicolumn{4}{|l|}{ Type of facility } \\
\hline Hospital & 88.0 & 90.4 & 83 \\
\hline Health Center/Clinic & 87.1 & 76.0 & 217 \\
\hline Community-based Health Planning & 91.3 & 55.3 & 300 \\
\hline \multicolumn{4}{|l|}{ Services (CHPS) } \\
\hline Maternity Home & 90.5 & 76.2 & 21 \\
\hline \multicolumn{4}{|l|}{ Location of facility } \\
\hline Rural & 91.2 & 62.0 & 434 \\
\hline Urban & 85.0 & 81.8 & 187 \\
\hline \multicolumn{4}{|l|}{ Managing authority } \\
\hline Government & 91.8 & 66.2 & 536 \\
\hline Private & 70.1 & 82.1 & 67 \\
\hline Mission/Faith-based & 88.9 & 66.7 & 18 \\
\hline \multicolumn{4}{|l|}{ Region } \\
\hline Ashanti & 82.6 & 69.7 & 287 \\
\hline Central & 92.6 & 77.0 & 122 \\
\hline Oti & 92.7 & 43.9 & 41 \\
\hline Upper East & 96.3 & 67.1 & 82 \\
\hline Volta & 98.9 & 61.8 & 89 \\
\hline \multicolumn{4}{|l|}{ Site } \\
\hline FP Pilot district & 96.6 & 66.1 & 59 \\
\hline Non-FP Pilot district & 88.6 & 68.1 & 562 \\
\hline Total & 555 & 422 & 621 \\
\hline Percent & 89.4 & 68.0 & 100.0 \\
\hline
\end{tabular}

\subsection{Provision of Family Planning Services}

Conditions under which FP services are provided are very critical for quality of care and uptake of FP services. To assess levels of privacy and confidentiality in the provision of FP services, the survey collected information on places or designated areas in the health facility where FP services are provided, availability of materials, and waiting time.

\subsubsection{Designated Area for Family Planning Service Provision}

Information on the designated areas where FP services are provided was elicited from the health facilities as they are key to providing quality FP services. The information comprised of whether there is a designated area/section of the facility where FP services are provided, whether there is a waiting area for FP clients, whether they have seats for FP clients in the waiting area, whether the seating area for FP clients is protected from sun and rain, and whether there is a toilet (latrine) in functional condition for FP clients' use (Table 4.4).

Close to 90 percent of the health facilities have a designated area for FP service provision including counseling. Fewer community-based health planning services (79\%) have a designated area/section for FP service provision including counseling compared to the other facility types. There are variations by location of the facility, managing authority, region, and site of the health facility. Majority of urban facilities $(93 \%)$ have a designated area/section of the facility for FP service provision compared to rural facilities. All mission/faith-based facilities (100\%) have a designated area/section of the health facility for FP service provision.

Over 90 percent of the health facilities have a waiting area for FP clients, where they are protected from sun and rain, 93 percent of health facilities have seats available for FP clients in the waiting areas, and approximately two-thirds of the health facilities have a toilet (latrine) in a functional condition which is available for FP service clients to use. 
Overall, at least $90 \%$ of all health facilities across the various levels of healthcare, rural and urban locations, managing authorities, regions, and study sites reported that there is a waiting area for FP clients, where they are protected from sun and rain. An equal proportion across background characteristics have seats for FP clients in the waiting area. 


\section{Table 4. 4 Designated area for family planning service provision and related amenities}

Percentage distribution of health facilities by whether there is a designated area/section of the facility where FP services are provided including counseling, percentage distribution of health facilities on whether there is a seating area for FP clients where they are protected from sun and rain, percentage distribution of facilities by whether they have seats for FP clients in the waiting area, and percentage distribution health facilities on whether there is a toilet (latrine) in a functional condition which is available for FP clients' use by background characteristics, FPNHIS 2021

\begin{tabular}{|c|c|c|c|c|c|}
\hline & $\begin{array}{c}\text { Have a designated area/section of the } \\
\text { facility where FP services are provided } \\
\text { including counseling }\end{array}$ & $\begin{array}{l}\text { Have a waiting area for FP } \\
\text { clients, where they are } \\
\text { protected from sun and rain }\end{array}$ & $\begin{array}{l}\text { Have seats for FP } \\
\text { clients in the } \\
\text { waiting area }\end{array}$ & $\begin{array}{l}\text { Have a toilet (latrine) in } \\
\text { functional condition that is } \\
\text { available for FP clients' use }\end{array}$ & $\begin{array}{c}\text { Total } \\
\text { number }\end{array}$ \\
\hline \multicolumn{6}{|l|}{ Type of facility } \\
\hline Hospital & 96.4 & 94.0 & 91.6 & 83.1 & 83 \\
\hline Health Center/Clinic & 95.4 & 94.9 & 93.1 & 70.5 & 217 \\
\hline \multicolumn{6}{|l|}{ Community-based Health } \\
\hline Planning Services (CHPS) & 79.0 & 93.3 & 92.7 & 54.0 & 300 \\
\hline Maternity Home & 85.7 & 100.0 & 100.0 & 85.7 & 21 \\
\hline \multicolumn{6}{|l|}{ Location of facility } \\
\hline Rural & 84.8 & 94.5 & 92.9 & 57.4 & 434 \\
\hline Urban & 93.0 & 93.6 & 93.0 & 81.8 & 187 \\
\hline \multicolumn{6}{|l|}{ Managing authority } \\
\hline Government & 86.8 & 93.7 & 92.5 & 61.2 & 536 \\
\hline Private & 88.1 & 97.0 & 97.0 & 92.5 & 67 \\
\hline Mission/Faith-based & 100.0 & 100.0 & 88.9 & 66.7 & 18 \\
\hline \multicolumn{6}{|l|}{ Region } \\
\hline Ashanti & 90.2 & 95.1 & 94.1 & 70.0 & 287 \\
\hline Central & 82.8 & 93.4 & 94.3 & 79.5 & 122 \\
\hline Oti & 95.1 & 95.1 & 90.2 & 39.0 & 41 \\
\hline Upper East & 79.3 & 92.7 & 90.2 & 51.2 & 82 \\
\hline Volta & 87.6 & 93.3 & 91.0 & 51.7 & 89 \\
\hline \multicolumn{6}{|l|}{ Site } \\
\hline FP Pilot district & 88.1 & 98.3 & 100.0 & 69.5 & 59 \\
\hline Non-FP Pilot district & 87.2 & 93.8 & 92.2 & 64.2 & 562 \\
\hline Total & 542 & 585 & 577 & 402 & 621 \\
\hline Percent & 87.3 & 94.2 & 92.9 & 64.7 & 100.0 \\
\hline
\end{tabular}




\subsubsection{Rooms for Family Planning Service Provision}

Having a designated room in the health facility for FP services and ensuring privacy and confidentiality are key steps towards providing quality services, hence the survey collected data on designated rooms for FP services. Table 4.5 describes the proportion of health facilities with a designated room for FP service provision, percentage distribution of health facilities that do not have a designated room for FP service provision but carry out FP services at other places in the health facility, and the proportion of health facilities who ensure privacy and confidentiality in the room where FP services are provided by background characteristics. In all, over 7 in 10 health facilities (74\%) have a designated room for FP service provision.

The least proportion of health facilities with a designated room for FP services are community-based health planning services (62\%). Most health facilities in urban areas (86\%) have a designated room for FP service provision compared to rural areas (69\%). Among the various managing authorities, a higher proportion of mission/faith-based health facilities (83\%), followed by private health facilities (79\%) have a designated room for FP service provision. Across the regions, more than 8 in 10 health facilities located in the Ashanti region have a designated room for FP service provision. Over 70 percent of health facilities in the non-FP pilot districts have a designated room for FP service provision.

Regarding health facilities that do not have designated rooms for FP services provision (161 out of 621 health facilities), over 9 in 10 of those hospitals, health centers/clinics, community-based health planning services, and maternity homes use shared rooms to provide FP services. Among health facilities that provide FP services in shared rooms, majority are in rural areas (99\%).

Overall, about 93 percent of health facilities ensure privacy and confidentiality in the room where FP services are provided. Pertaining to the type of facility, all maternity homes ensure privacy and confidentiality in the rooms where FP services are provided. Facilities located in urban communities (95\%), privately owned (99\%), located in the Central region (98\%), and all facilities in the FP Pilot districts (100\%) ensure privacy and confidentiality in the room where FP services are provided. 
Table 4. 5 Rooms, privacy, and confidentiality in family planning service provision

Percentage distribution of health facilities with a designated room for FP service provision, percentage distribution of health facilities who do not have a designated room for FP service provision in the health facility, and percentage distribution of health facilities by whether privacy and confidentiality are ensured in the room where FP services are provided by background characteristics, FPNHIS 2021

\begin{tabular}{|c|c|c|c|c|c|c|c|}
\hline & \multirow{2}{*}{$\begin{array}{l}\text { Have a designated } \\
\text { room for FP } \\
\text { service provision }\end{array}$} & \multirow[b]{2}{*}{ Total number } & \multicolumn{2}{|c|}{$\begin{array}{c}\text { Places other than } \\
\text { designated room where } \\
\text { FP services are provided } \\
\text { in the facility: } \\
\end{array}$} & \multirow[b]{2}{*}{ Total number } & \multirow{2}{*}{$\begin{array}{c}\text { Privacy and } \\
\text { confidentiality are } \\
\text { ensured in the room } \\
\text { FP services are } \\
\text { provided }\end{array}$} & \multirow[b]{2}{*}{ Total numbe } \\
\hline & & & $\begin{array}{c}\text { Shared } \\
\text { room }\end{array}$ & Other & & & \\
\hline \multicolumn{8}{|l|}{ Type of Facility } \\
\hline Hospital & 94.0 & 83 & 100.0 & 0.0 & 5 & 95.2 & 83 \\
\hline Health Center/Clinic & 82.0 & 217 & 97.4 & 2.6 & 39 & 94.5 & 217 \\
\hline Community-based Health & 61.7 & 300 & 97.4 & 2.6 & 115 & & \\
\hline Planning Services (CHPS) & & & & & & 90.3 & 300 \\
\hline Maternity Home & 90.5 & 21 & 100.0 & 0.0 & 2 & 100.0 & 21 \\
\hline \multicolumn{8}{|l|}{ Location of facility } \\
\hline Rural & 68.9 & 434 & 98.5 & 1.5 & 135 & 91.9 & 434 \\
\hline Urban & 86.1 & 187 & 92.3 & 7.7 & 26 & 94.7 & 187 \\
\hline \multicolumn{8}{|l|}{ Managing authority } \\
\hline Government & 73.1 & 536 & 97.2 & 2.8 & 144 & 92.5 & 536 \\
\hline Private & 79.1 & 67 & 100.0 & 0.0 & 14 & 98.5 & 67 \\
\hline Mission/Faith-based & 83.3 & 18 & 100.0 & 0.0 & 3 & 77.8 & 18 \\
\hline \multicolumn{8}{|l|}{ Region } \\
\hline Ashanti & 86.1 & 287 & 92.5 & 7.5 & 40 & 94.1 & 287 \\
\hline Central & 77.9 & 122 & 100.0 & 0.0 & 27 & 97.5 & 122 \\
\hline Oti & 68.3 & 41 & 100.0 & 0.0 & 13 & 92.7 & 41 \\
\hline Upper East & 46.3 & 82 & 97.7 & 2.3 & 44 & 95.1 & 82 \\
\hline Volta & 58.4 & 89 & 100.0 & 0.0 & 37 & 79.8 & 89 \\
\hline \multicolumn{8}{|l|}{ Site } \\
\hline FP Pilot district & 62.7 & 59 & 100.0 & 0.0 & 22 & 100.0 & 59 \\
\hline Non-FP Pilot district & 75.3 & 562 & 97.1 & 2.9 & 139 & 92.0 & 562 \\
\hline Total & 460 & 621 & 157 & 4 & 161 & 576 & 621 \\
\hline Percent & 74.1 & 100.0 & 97.5 & 2.5 & 100.0 & 92.8 & 100.0 \\
\hline
\end{tabular}




\subsubsection{Evidence of Availability of Family Planning Materials}

Through observation, the FPNHIS assessed the availability of specific FP materials in the room where services are provided. Table 4.6 presents the percentage distribution of observed family planning materials by background characteristics. In all, the most available materials in the room where FP services are provided are samples of various FP methods (e.g., condoms, injectables, oral contraceptives) (96\%), followed by counseling flip charts (93\%), penis model (77\%), posters for general promotion of FP (69\%), WHO Medical Eligibility Criteria wheel (60\%), and FP service protocol (58\%). Less than half of the health facilities have the pregnancy checklist (47\%), IUD model (30\%), and other materials (1\%) available in the FP service provision room.

The highest percentage of health facilities that have counseling flip charts are maternity homes (95\%), while health centers/clinics (97\%) and community-based health planning services $(97 \%)$ mostly have samples of various FP methods available in the FP service provision rooms. With regards to the location of health facilities, samples of various FP methods are two percentage points higher in rural areas (97\%) compared to urban areas (95\%). Pertaining to the managing authority, there is universal availability of counseling flip charts in mission/faith-based health facilities. All health facilities in the Oti region have samples of various FP methods and counseling flip charts. 
Table 4. 6 Materials available in the room for family planning service provision

Percentage distribution of health facilities with materials (observed) in rooms where family planning services are provided by background characteristics, FPNHIS 2021

\begin{tabular}{|c|c|c|c|c|c|c|c|c|c|c|}
\hline & $\begin{array}{l}\text { Samples } \\
\text { of } \\
\text { various } \\
\text { FP } \\
\text { methods }\end{array}$ & $\begin{array}{l}\text { Penis } \\
\text { model }\end{array}$ & $\begin{array}{l}\text { IUD } \\
\text { model }\end{array}$ & $\begin{array}{l}\text { Posters for } \\
\text { general } \\
\text { promotion of } \\
\text { FP }\end{array}$ & $\begin{array}{c}\text { Counseling flip } \\
\text { charts }\end{array}$ & $\begin{array}{l}\text { Pregnancy } \\
\text { checklist }\end{array}$ & $\begin{array}{c}\text { WHO } \\
\text { Medical } \\
\text { Eligibility } \\
\text { Criteria } \\
\text { wheel }\end{array}$ & $\begin{array}{l}\text { FP service } \\
\text { protocol }\end{array}$ & Other & Total \\
\hline \multicolumn{11}{|l|}{ Type of Facility } \\
\hline Hospital & 91.6 & 85.5 & 59.0 & 77.1 & 92.8 & 68.7 & 74.7 & 68.7 & 1.2 & 83 \\
\hline Health Center/Clinic & 97.2 & 86.6 & 37.3 & 72.4 & 94.0 & 47.9 & 65.9 & 64.5 & 0.5 & 217 \\
\hline $\begin{array}{l}\text { Community-based Health } \\
\text { Planning Services (CHPS) }\end{array}$ & 97.0 & 69.0 & 14.3 & 64.3 & 91.7 & 40.0 & 51.7 & 49.3 & 0.3 & 300 \\
\hline Maternity Home & 90.5 & 61.9 & 52.4 & 61.9 & 95.2 & 47.6 & 47.6 & 57.1 & 0.0 & 21 \\
\hline \multicolumn{11}{|l|}{ Location of facility } \\
\hline Rural & 96.8 & 74.4 & 21.4 & 67.1 & 91.9 & 42.9 & 58.8 & 53.7 & 0.5 & 434 \\
\hline Urban & 94.7 & 83.4 & 48.7 & 72.7 & 94.7 & 56.2 & 61.5 & 66.3 & 0.5 & 187 \\
\hline \multicolumn{11}{|l|}{ Managing authority } \\
\hline Government & 97.6 & 78.4 & 27.8 & 69.4 & 93.5 & 46.3 & 61.4 & 58.4 & 0.4 & 536 \\
\hline Private & 85.1 & 64.2 & 44.8 & 64.2 & 85.1 & 49.3 & 44.8 & 47.8 & 1.5 & 67 \\
\hline Mission/Faith-based & 94.4 & 88.9 & 27.8 & 66.7 & 100.0 & 55.6 & 61.1 & 66.7 & 0.0 & 18 \\
\hline \multicolumn{11}{|l|}{ Region } \\
\hline Ashanti & 94.8 & 84.7 & 31.4 & 64.8 & 93.4 & 54.4 & 65.2 & 57.8 & 0.4 & 287.0 \\
\hline Central & 97.5 & 81.2 & 41.0 & 73.8 & 98.4 & 41.8 & 54.9 & 78.7 & 0.0 & 122.0 \\
\hline Oti & 100.0 & 68.3 & 24.4 & 73.2 & 100.0 & 39.0 & 78.1 & 46.3 & 0.0 & 41.0 \\
\hline Upper East & 93.9 & 61.0 & 19.5 & 70.7 & 79.3 & 50.0 & 30.5 & 36.6 & 2.4 & 82.0 \\
\hline Volta & 98.9 & 66.3 & 20.2 & 70.8 & 92.1 & 30.3 & 66.3 & 51.7 & 0.0 & 89.0 \\
\hline \multicolumn{11}{|l|}{ Site } \\
\hline FP Pilot district & 96.6 & 67.8 & 42.4 & 84.8 & 89.8 & 59.3 & 50.9 & 52.5 & 0.0 & 59 \\
\hline Non-FP Pilot district & 96.1 & 78.1 & 28.3 & 67.1 & 93.1 & 45.6 & 60.5 & 58.0 & 0.5 & 562 \\
\hline Total & 597 & 479 & 184 & 427 & 576 & 291 & 370 & 357 & 3 & 621 \\
\hline Percent & 96.1 & 77.1 & 29.6 & 68.8 & 92.8 & 46.9 & 59.6 & 57.5 & 0.5 & 100.0 \\
\hline
\end{tabular}




\subsubsection{Availability of Materials for Family Planning Counseling}

The survey collected information on materials and aids used to counsel clients about the use of contraceptive methods as the availability of these materials can affect the quality of FP counseling. Table 4.7 presents the availability of materials used to counsel clients about the use of contraceptive methods by background characteristics. Overall, 96 percent of the health facilities have visual aids whilst 76 percent have models and samples. Only 1 percent of the health facilities have no materials available.

At least 95 percent of all types of health facilities have visual aids such as flip charts and posters. However, up to 5 percent of maternity homes and 4 percent of hospitals have no materials available.

Very few geographical differences existed between the availability of visual aids in rural (97\%) or urban (95\%) locations of facilities. In terms of management, there is universal availability of visual aids in mission/faithbased managed health facilities.

Also, the availability of commodity samples (78\%) and models (78\%) are highest among facilities managed by mission/faith-based authorities. In terms of regional variations, only Central and Oti regions have 100 percent coverage of visual aid materials. Less than half (46\%) of the health facilities in Oti region have models or samples, which is the lowest across the regions. 


\section{Table 4. 7 Materials for family planning counseling}

Percentage distribution of materials used to counsel clients about the use of contraceptive methods by background characteristics, FPNHIS 2021

\begin{tabular}{|c|c|c|c|c|c|c|}
\hline & $\begin{array}{l}\text { Have visual } \\
\text { aids (i.e., flip } \\
\text { charts and } \\
\text { posters) }\end{array}$ & Have models & $\begin{array}{c}\text { Have samples of } \\
\text { commodities }\end{array}$ & $\begin{array}{l}\text { Have no } \\
\text { materials } \\
\text { available }\end{array}$ & Have other materials & Total number \\
\hline \multicolumn{7}{|l|}{ Type of Facility } \\
\hline Hospital & 95.2 & 81.9 & 81.9 & 3.6 & 1.2 & 83 \\
\hline Health Center/Clinic & 96.8 & 82.9 & 83.0 & 0.5 & 2.3 & 217 \\
\hline Community-based Health Planning Services (CHPS) & 96.0 & 69.7 & 69.7 & 0.3 & 0.7 & 300 \\
\hline Maternity Home & 95.2 & 57.1 & 57.1 & 4.8 & 0.0 & 21 \\
\hline \multicolumn{7}{|l|}{ Location of facility } \\
\hline Rural & 96.8 & 73.3 & 73.3 & 0.5 & 1.4 & 434 \\
\hline Urban & 94.7 & 80.7 & 80.8 & 2.1 & 1.1 & 187 \\
\hline \multicolumn{7}{|l|}{ Managing authority } \\
\hline Government & 96.8 & 77.2 & 77.2 & 0.8 & 1.3 & 536 \\
\hline Private & 89.6 & 61.2 & 61.2 & 3.0 & 1.5 & 67 \\
\hline Mission/Faith-based & 100.0 & 77.8 & 77.8 & 0.0 & 0.0 & 18 \\
\hline \multicolumn{7}{|l|}{ Region } \\
\hline Ashanti & 95.5 & 83.6 & 83.6 & 1.1 & 1.4 & 287 \\
\hline Central & 100.0 & 82.0 & 82.0 & 0.0 & 0.0 & 122 \\
\hline Oti & 100.0 & 46.3 & 46.3 & 0.0 & 2.4 & 41 \\
\hline Upper East & 96.3 & 69.5 & 69.5 & 3.7 & 0.0 & 82 \\
\hline Volta & 91.0 & 59.6 & 59.6 & 0.0 & 3.4 & 89 \\
\hline \multicolumn{7}{|l|}{ Site } \\
\hline FP Pilot district & 98.3 & 71.2 & 94.9 & 1.7 & 1.7 & 59 \\
\hline Non-FP Pilot district & 95.9 & 76.0 & 96.3 & 0.9 & 1.3 & 562 \\
\hline $\begin{array}{l}\text { Total } \\
\text { Percent }\end{array}$ & $\begin{array}{l}597 \\
96.1\end{array}$ & $\begin{array}{l}469 \\
75.5\end{array}$ & $\begin{array}{l}469 \\
75.5\end{array}$ & $\begin{array}{c}6 \\
1.0\end{array}$ & $\begin{array}{c}8 \\
1.3\end{array}$ & $\begin{array}{c}621 \\
100.0\end{array}$ \\
\hline
\end{tabular}




\subsubsection{Average Waiting Time for Clients}

Another quality of FP issue that was also assessed is the waiting time for clients to see an FP provider. Waiting time was defined as the total time from the time a client arrives at the FP service provision point until the beginning of consultation with a provider. Table 4.8 presents the average waiting time for clients to see an FP provider by background characteristics.

In general, it took an average of about 12 minutes for an FP client to see a provider, ranging between 0 and 45 minutes. The mean waiting times for different types of health facilities ranged from an average of 11 minutes for community-based health planning services to an average of 16 minutes in maternity homes.

Urban-rural variations are minimal; (12 minutes, rural) and (13 minutes, urban). With respect to managing authorities, mission/faith-based health facilities recorded the lowest mean waiting time of 10 minutes with the maximum waiting time being 30 minutes.

Privately managed health facilities recorded the highest average waiting time which was 15 minutes. Across study regions, Oti region recorded the lowest waiting time of 9 minutes followed by Upper East (10 minutes), and Ashanti region (11 minutes). FP Pilot districts recorded less average waiting time (11 minutes) than non-FP Pilot districts (12 minutes).

Table 4. 8 Average waiting times for family planning service provision Average waiting time (minutes) for a client to be seen by an FP provider by background characteristics, FPNHIS 2021

\begin{tabular}{|c|c|c|c|c|c|}
\hline & Total number & Mean & std. dev. & Min. & Max \\
\hline \multicolumn{6}{|l|}{ Type of facility } \\
\hline Hospital & 83 & 13.5 & 8.7 & 2 & 30 \\
\hline \multicolumn{6}{|l|}{ Health } \\
\hline Center/Clinic & 217 & 12.7 & 9.7 & 1 & 45 \\
\hline \multicolumn{6}{|l|}{ Community-based } \\
\hline \multicolumn{6}{|l|}{ Health Planning } \\
\hline Services (CHPS) & 300 & 11.2 & 9.1 & 0 & 45 \\
\hline Maternity Home & 21 & 16.2 & 12.9 & 0 & 45 \\
\hline \multicolumn{6}{|l|}{ Location of facility } \\
\hline Rural & 434 & 11.9 & 9.5 & 0 & 45 \\
\hline Urban & 187 & 12.9 & 9.3 & 1 & 45 \\
\hline \multicolumn{6}{|l|}{ Managing authority } \\
\hline Government & 536 & 11.9 & 9.3 & 0 & 45 \\
\hline Private & 67 & 14.7 & 10.6 & 0 & 45 \\
\hline \multicolumn{6}{|l|}{ Mission/Faith- } \\
\hline based & 18 & 10.3 & 6.9 & 2 & 30 \\
\hline \multicolumn{6}{|l|}{ Region } \\
\hline Ashanti & 287 & 10.8 & 9.0 & 0 & 45 \\
\hline Central & 122 & 13.3 & 10.4 & 1 & 45 \\
\hline Oti & 41 & 9.0 & 7.4 & 1 & 30 \\
\hline Upper East & 82 & 10.1 & 9.1 & 0 & 45 \\
\hline Volta & 89 & 18.3 & 8.1 & 5 & 45 \\
\hline \multicolumn{6}{|l|}{ Site } \\
\hline FP Pilot district & 59 & 10.6 & 9.9 & 0 & 4 \\
\hline Non-FP Pilot district & 562 & 12.4 & 9.4 & 0 & 45 \\
\hline Total & 621 & 12.2 & 9.5 & 0 & 45 \\
\hline
\end{tabular}

\subsubsection{Routine Tests for Family Planning Services}

The FPNHIS study collected information on tests that are routinely conducted on FP service clients. Table 4.9 presents information on tests routinely conducted on women when they visit health facilities for FP services. In all, the highest proportion of the health facilities conduct pregnancy tests (97\%), followed by HIV tests (47\%) and urine tests (30\%) on women prior to family planning service provision. Pap smear (4\%) and other tests $(8 \%)$ are the least conducted in the health facilities.

Comparing types of health facilities, all maternity homes $(100 \%)$ routinely conduct pregnancy tests on women who visit for FP services. Similarly, across locations, a higher proportion of health facilities in rural areas (98\%) conduct pregnancy tests on FP service clients than those in urban areas (95\%). With regards to region and study site, all heath facilities in Oti region (100\%) and 95 percent of health facilities in the FP Pilot districts routinely conduct pregnancy tests on FP service clients. 
Table 4. 9 Routinely conducted tests on family planning clients

Percentage distribution of tests that are routinely conducted on women when they visit health facilities for family planning services by background characteristics, FPNHIS 2021

\begin{tabular}{|c|c|c|c|c|c|c|}
\hline & HIV test & Urine test & Pap smear & Pregnancy test & Other tests & Total number \\
\hline \multicolumn{7}{|l|}{ Type of facility } \\
\hline Hospital & 50.6 & 38.6 & 2.4 & 91.6 & 10.8 & 83 \\
\hline Health Center/Clinic & 47.5 & 29.0 & 4.6 & 96.8 & 10.1 & 217 \\
\hline Community-based Health Planning Services (CHPS) & 46.7 & 30.0 & 3.3 & 98.0 & 5.0 & 300 \\
\hline Maternity Home & 38.1 & 14.3 & 4.8 & 100.0 & 14.3 & 21 \\
\hline \multicolumn{7}{|l|}{ Location of facility } \\
\hline Rural & 48.4 & 30.2 & 2.8 & 97.5 & 6.2 & 434 \\
\hline Urban & 44.4 & 30.5 & 5.9 & 95.2 & 11.8 & 187 \\
\hline \multicolumn{7}{|l|}{ Managing Authority } \\
\hline Government & 50.2 & 30.4 & 3.5 & 97.4 & 8.0 & 537 \\
\hline Private & 26.9 & 25.4 & 4.5 & 92.5 & 7.5 & 67 \\
\hline Mission/Faith-based & 33.3 & 44.4 & 5.6 & 94.4 & 5.6 & 18 \\
\hline \multicolumn{7}{|l|}{ Region } \\
\hline Ashanti & 25.4 & 33.4 & 3.5 & 95.5 & 11.5 & 287 \\
\hline Central & 56.6 & 21.3 & 2.5 & 99.2 & 8.2 & 122 \\
\hline Oti & 82.9 & 9.8 & 0.0 & 100.0 & 0.0 & 41 \\
\hline Upper East & 69.5 & 61.0 & 4.9 & 96.3 & 2.4 & 82 \\
\hline Volta & 67.4 & 13.5 & 6.7 & 96.6 & 4.5 & 89 \\
\hline \multicolumn{7}{|l|}{ Site } \\
\hline FP Pilot Districts & 37.3 & 50.8 & 6.8 & 94.9 & 6.8 & 59 \\
\hline Non-FP Pilot Districts & 48.2 & 28.1 & 3.4 & 97.0 & 8.0 & 562 \\
\hline Total & 293 & 188 & 23 & 601 & 49 & 621 \\
\hline Percent & 47.2 & 30.3 & 3.7 & 96.8 & 7.9 & 100.0 \\
\hline
\end{tabular}




\subsection{Family Planning Service Readiness}

As the country considers the inclusion of FP services into the NHIS, it is important to assess the readiness of health facilities with respect to scale-up. The FPNHIS collected information on the human resource capacity of health facilities to provide FP services, availability of FP commodities, commodity stock-outs, and the availability of FP equipment and supplies.

\subsubsection{Capacity to Provide Family Planning Services}

The FPNHIS collected information on health facilities capacity to provide FP services to clients by asking whether the health facility is able to provide services to all FP clients each day and whether the health facility has enough capacity to provide FP services if there was an increase in demand resulting from the removal of out-of-pocket costs. Table 4.10 shows the percentage distribution of health facilities that can provide FP services to all clients daily and the capacity of health facilities to provide FP services if there is an increase in demand.

Generally, 94 percent of the health facilities can provide FP service to all clients each day. Hospitals have the highest (96\%) ability to provide FP service to all clients each day whilst the lowest is among maternity homes (91\%). The ability of health facilities to provide services to all FP clients each day is slightly higher among rural health facilities (95\%) than urban (93\%) health facilities. All health facilities under mission/faithbased management are able to provide FP services to all clients each day and private health facilities have the least ability to provide services to all clients each day (91\%). Provision of FP services to all clients each day is highest in the Oti region (100\%) and lowest in the Central region (88\%). There is minimal difference in the ability to provide FP services to all clients each day between health facilities in the FP Pilot (95\%) and non-FP Pilot (94\%) districts.

In terms of whether health facilities have the capacity to provide FP services to clients if there is an increase in demand, 91 percent of all the health facilities reported in the affirmative. At least 88 percent of all the health facility types have enough capacity to provide FP services in the event of increased demand, with hospitals (95\%) being the highest. Oti region leads in the capability to provide FP services in the event of increased demand (100\%). The capacity to provide FP services in the event of increased demand is generally high with Upper East region (87\%) recording the least. Non-FP Pilot district health facilities have a higher (92\%) capacity to provide FP services during increased demand than the health facilities in the FP Pilot districts (88\%). 
Table 4. 10 Capacity to provide family planning services

Percentage distribution of health facilities able to provide services to ALL FP clients each day, and percentage distribution of health facilities with enough capacity to provide FP services to clients if there is an increase in demand by background characteristics, FPNHIS 2021

\begin{tabular}{|c|c|c|c|c|}
\hline - & $\begin{array}{c}\text { Health facility can provide } \\
\text { services to ALL FP clients each } \\
\text { day }\end{array}$ & Total number & $\begin{array}{l}\text { Health facility has enough capacity to } \\
\text { provide FP services to clients if there } \\
\text { is an increase in demand }\end{array}$ & Total number \\
\hline \multicolumn{5}{|l|}{ Type of Facility } \\
\hline Hospital & 96.4 & 83 & 95.2 & 83 \\
\hline Health Center/Clinic & 93.5 & 217 & 94.5 & 217 \\
\hline Community-based Health Planning Services (CHPS) & 94.3 & 300 & 87.7 & 300 \\
\hline Maternity Home & 90.5 & 21 & 90.5 & 21 \\
\hline \multicolumn{5}{|l|}{ Location of facility } \\
\hline Rural & 94.7 & 434 & 90.8 & 434 \\
\hline Urban & 93.0 & 187 & 92.0 & 187 \\
\hline \multicolumn{5}{|l|}{ Managing authority } \\
\hline Government & 94.4 & 536 & 91.0 & 536 \\
\hline Private & 91.0 & 67 & 91.0 & 67 \\
\hline Mission/Faith-based & 100.0 & 18 & 94.4 & 18 \\
\hline \multicolumn{5}{|l|}{ Region } \\
\hline Ashanti & 96.5 & 287 & 89.5 & 287 \\
\hline Central & 87.7 & 122 & 94.3 & 122 \\
\hline Oti & 100.0 & 41 & 100.0 & 41 \\
\hline Upper East & 97.6 & 82 & 86.6 & 82 \\
\hline Volta & 89.9 & 89 & 92.1 & 89 \\
\hline \multicolumn{5}{|l|}{ Site } \\
\hline FP Pilot district & 94.9 & 59 & 88.1 & 59 \\
\hline Non-FP Pilot district & 94.1 & 562 & 91.5 & 562 \\
\hline $\begin{array}{l}\text { Total } \\
\text { Percent }\end{array}$ & $\begin{array}{l}585 \\
94.2 \\
\end{array}$ & $\begin{array}{c}621 \\
100.0\end{array}$ & $\begin{array}{l}566 \\
91.1 \\
\end{array}$ & $\begin{array}{c}621 \\
100.0\end{array}$ \\
\hline
\end{tabular}




\subsubsection{Family Planning Staff}

The average number of staff trained to provide FP services and the average number of staff providing FP services in health facilities are key indicators of the capacity of health facilities to provide FP services. Table 4.11 provides details on the available human resources for the provision of FP services in the health facilities. The analysis considered 592 out of 621 health facilities with complete information for both indicators. On average the number of staff trained to provide FP services in the health facilities is 10 , however, on average only 8 of the staff trained to provide FP services are providing FP services.

Hospitals have the highest average number of staff trained to provide FP services (33) as well as the number of trained FP providers providing services (19). The average number of staff trained to provide FP services is higher in urban areas (20) compared to rural areas (6). Although not pronounced, Table 4.11 also shows that in some health facilities, some of the service providers providing FP services are not trained. For instance, in Oti and Upper East regions, the average number of staff providing FP services is slightly higher than those trained to provide FP services.

\begin{tabular}{|c|c|c|c|c|c|c|c|c|}
\hline & \multicolumn{4}{|c|}{$\begin{array}{c}\text { Average number staff trained to provide FP } \\
\text { services }\end{array}$} & \multicolumn{4}{|c|}{$\begin{array}{c}\text { Average number of staff providing FP } \\
\text { services }\end{array}$} \\
\hline & Total number & Mean & Min. & Max. & Total number & Mean & Min. & Max. \\
\hline \multicolumn{9}{|l|}{ Type of Facility } \\
\hline $\begin{array}{l}\text { Hospital } \\
\text { Health }\end{array}$ & 80 & 32.5 & 3 & 513 & 80 & 18.9 & 1 & 146 \\
\hline $\begin{array}{l}\text { Centre/Clinic } \\
\text { Community- } \\
\text { based Health } \\
\text { Planning }\end{array}$ & 211 & 10.5 & 1 & 96 & 211 & 8.5 & 1 & 56 \\
\hline Services (CHPS) & 280 & 3.9 & 1 & 60 & 280 & 4.1 & 1 & 55 \\
\hline Maternity Home & 21 & 4.4 & 1 & 15 & 21 & 4.4 & 2 & 14 \\
\hline \multicolumn{9}{|l|}{$\begin{array}{l}\text { Location of } \\
\text { facility }\end{array}$} \\
\hline Rural & 415 & 6.0 & 1 & 60 & 415 & 5.8 & 1 & 56 \\
\hline Urban & 177 & 19.9 & 1 & 513 & 177 & 12.0 & 1 & 146 \\
\hline \multicolumn{9}{|l|}{$\begin{array}{l}\text { Managing } \\
\text { authority }\end{array}$} \\
\hline Government & 510 & 9.6 & 1 & 513 & 510 & 7.6 & 1 & 146 \\
\hline Private & 66 & 10.4 & 1 & 51 & 66 & 6.3 & 1 & 21 \\
\hline $\begin{array}{l}\text { Mission/Faith- } \\
\text { based }\end{array}$ & 16 & 26.4 & 1 & 96 & 16 & 14.3 & 1 & 71 \\
\hline \multicolumn{9}{|l|}{ Region } \\
\hline Ashanti & 273 & 14.3 & 1 & 513 & 273 & 9.5 & 1 & 146 \\
\hline Central & 120 & 7.0 & 1 & 39 & 120 & 6.4 & 1 & 40 \\
\hline Oti & 40 & 5.5 & 1 & 20 & 40 & 5.8 & 2 & 19 \\
\hline Upper East & 70 & 6.8 & 1 & 56 & 70 & 7.1 & 1 & 56 \\
\hline Volta & 89 & 6.5 & 1 & 85 & 89 & 5.1 & 1 & 26 \\
\hline \multicolumn{9}{|l|}{ Site } \\
\hline $\begin{array}{l}\text { FP Pilot district } \\
\text { Non-FP Pilot }\end{array}$ & 59 & 6.3 & 1 & 28 & 59 & 5.9 & 1 & 28 \\
\hline district & 533 & 10.6 & 1 & 513 & 533 & 7.9 & 1 & 146 \\
\hline Total & 592 & 10.1 & 1 & 513 & 592 & 7.7 & 1 & 146 \\
\hline
\end{tabular}




\subsubsection{Cadre of staff providing family planning services}

The capacity of health facilities to provide different types of FP methods to clients is important in assessing the readiness of health facilities. FP methods that can be provided by health personnel vary by cadre of health providers.

According to the Ghana National Family Planning Protocols, in the provision of FP services, doctors can provide counseling, long-acting reversible contraceptives (LARCs), short-acting reversible methods (SARCs), and permanent methods (PMs). Midwives, state-registered nurses (SRNs), public health nurses (PHNs), enrolled nurses (ENs), community health nurses (CHNs), and Medical/Physician Assistants with midwifery training, are expected to provide FP counseling, LARCs, whereas community pharmacists are expected to provide information on FP to clients and SARCs.

Tables $4.12 \mathrm{a}$ and $4.12 \mathrm{~b}$ show the percentage distribution of different cadre of staff who provide FP counseling, LARCs, and PMs by background characteristics. The highest proportion of health facilities (88\%) have a CHN providing FP counseling, followed by midwives (57\%) and ENs (31\%). The pattern is similar for the provision of LARCs, CHNs (84\%) are the highest, followed by midwives (58\%), and ENs (23\%). Only medical doctors are allowed to provide PMs and 10 percent of the health facilities have a doctor providing permanent FP methods services. 
Table 4. 12a Staff providing long-acting reversible contraceptives and permanent methods

Percentage distribution of health facilities with different cadre of staff providing counseling, long-acting reversible contraceptives, and permanent methods, FPNHIS 2021

\begin{tabular}{|c|c|c|c|c|c|c|c|c|c|c|}
\hline & $\begin{array}{l}\text { Doctors: } \\
\text { Counseling }\end{array}$ & $\begin{array}{l}\text { Doctors: } \\
\text { LARCs }\end{array}$ & $\begin{array}{l}\text { Doctors: } \\
\text { PMs }\end{array}$ & $\begin{array}{l}\text { Medical/Physician } \\
\text { Assistants: } \\
\text { Counseling }\end{array}$ & $\begin{array}{l}\text { Medical/Physician } \\
\text { Assistants: LARCs }\end{array}$ & $\begin{array}{c}\text { PHNs: } \\
\text { Counseling }\end{array}$ & $\begin{array}{l}\text { PHNs: } \\
\text { LARCs }\end{array}$ & $\begin{array}{l}\text { Midwives: } \\
\text { Counseling }\end{array}$ & $\begin{array}{l}\text { Midwives: } \\
\text { LARCs }\end{array}$ & $\begin{array}{l}\text { Total } \\
\text { Number }\end{array}$ \\
\hline \multicolumn{11}{|l|}{ Type of Facility } \\
\hline Hospital & 21.7 & 18.1 & 59.0 & 14.5 & 3.6 & 34.9 & 28.9 & 60.2 & 74.7 & 83 \\
\hline Health Center/Clinic & 4.1 & 3.7 & 4.1 & 31.8 & 13.4 & 12.4 & 12.0 & 65.4 & 71.4 & 217 \\
\hline Community-based Health Planning Services (CHPS) & 0.7 & 0.0 & 0.3 & 4.0 & 2.7 & 4.3 & 4.0 & 46.7 & 41.7 & 300 \\
\hline Maternity Home & 9.5 & 9.5 & 4.8 & 19.0 & 19.0 & 14.3 & 14.3 & 95.2 & 81.0 & 21 \\
\hline \multicolumn{11}{|l|}{ Location of facility } \\
\hline Rural & 3.2 & 1.6 & 3.2 & 15.4 & 7.6 & 7.6 & 7.4 & 58.8 & 57.4 & 434 \\
\hline Urban & 9.1 & 9.6 & 24.6 & 16.0 & 5.9 & 20.9 & 17.6 & 51.9 & 58.8 & 187 \\
\hline \multicolumn{11}{|l|}{ Managing authority } \\
\hline Government & 3.2 & 2.1 & 6.9 & 14.9 & 6.9 & 10.3 & 9.0 & 54.9 & 56.9 & 536 \\
\hline Private & 19.4 & 19.4 & 29.9 & 19.4 & 9.0 & 13.4 & 11.9 & 71.6 & 68.7 & 67 \\
\hline Mission/Faith-based & 5.6 & 5.6 & 16.7 & 22.2 & 5.6 & 44.4 & 50.0 & 55.6 & 44.4 & 18 \\
\hline \multicolumn{11}{|l|}{ Region } \\
\hline Ashanti & 6.6 & 5.9 & 12.9 & 17.8 & 10.1 & 13.6 & 11.8 & 64.5 & 57.1 & 287 \\
\hline Central & 3.3 & 2.5 & 10.7 & 19.7 & 5.7 & 6.6 & 5.7 & 52.5 & 61.5 & 122 \\
\hline Oti & 4.9 & 0.0 & 9.8 & 2.4 & 0.0 & 7.3 & 7.3 & 63.4 & 56.1 & 41 \\
\hline Upper East & 6.1 & 4.9 & 2.4 & 15.9 & 8.5 & 17.1 & 15.9 & 57.3 & 59.8 & 82 \\
\hline Volta & 1.1 & 1.1 & 4.5 & 9.0 & 1.1 & 9.0 & 9.0 & 33.7 & 53.9 & 89 \\
\hline \multicolumn{11}{|l|}{ Site } \\
\hline Intervention & 1.7 & 3.4 & 5.1 & 11.9 & 5.1 & 8.5 & 8.5 & 54.2 & 57.6 & 59 \\
\hline Control & 5.3 & 4.1 & 10.1 & 16.0 & 7.3 & 11.9 & 10.7 & 56.9 & 57.8 & 562 \\
\hline Total & 31 & 25 & 60 & 97 & 44 & 72 & 65 & 352 & 359 & 621 \\
\hline Percent & 5.0 & 4.0 & 9.7 & 15.6 & 7.1 & 11.6 & 10.5 & 56.7 & 57.8 & 100.0 \\
\hline
\end{tabular}


Table 4.12b Staff providing long-acting reversible contraceptives and permanent methods

Percentage distribution of different cadre of staff providing long-acting reversible contraceptives and permanent methods, FPNHIS 2021

\begin{tabular}{|c|c|c|c|c|c|c|c|c|}
\hline & $\begin{array}{l}\text { SRNs: } \\
\text { Counseling }\end{array}$ & $\begin{array}{l}\text { SRNs: } \\
\text { LARCs }\end{array}$ & $\begin{array}{c}\text { CHNs: } \\
\text { Counseling }\end{array}$ & $\begin{array}{l}\text { CHNs: } \\
\text { LARCs }\end{array}$ & $\begin{array}{c}\text { ENs: } \\
\text { Counseling }\end{array}$ & $\begin{array}{c}\text { ENs: } \\
\text { LARCs }\end{array}$ & $\begin{array}{c}\text { Pharmacists: } \\
\text { Counseling }\end{array}$ & $\begin{array}{c}\text { Total } \\
\text { Number }\end{array}$ \\
\hline \multicolumn{9}{|l|}{ Type of Facility } \\
\hline Hospital & 13.3 & 9.6 & 78.3 & 73.5 & 8.4 & 7.2 & 2.4 & 83 \\
\hline Health Center/Clinic & 24.4 & 18.4 & 89.4 & 88.0 & 22.6 & 17.1 & 2.3 & 217 \\
\hline Community-based Health Planning Services (CHPS) & 11.0 & 7.7 & 92.7 & 88.3 & 43.3 & 30.3 & 0.3 & 300 \\
\hline Maternity Home & 23.8 & 14.3 & 33.3 & 28.6 & 38.1 & 38.1 & 0.0 & 21 \\
\hline \multicolumn{9}{|l|}{ Location of facility } \\
\hline Rural & 16.8 & 12.2 & 92.4 & 89.2 & 36.9 & 27.9 & 1.6 & 434 \\
\hline Urban & 15.5 & 11.2 & 76.5 & 72.7 & 18.2 & 11.2 & 0.5 & 187 \\
\hline \multicolumn{9}{|l|}{ Managing authority } \\
\hline Government & 16.2 & 12.1 & 92.7 & 89.7 & 32.5 & 23.3 & 1.1 & 536 \\
\hline Private & 19.4 & 11.9 & 47.8 & 38.8 & 26.9 & 23.9 & 3.0 & 67 \\
\hline Mission/Faith-based & 11.1 & 5.6 & 83.3 & 88.9 & 11.1 & 5.6 & 0.0 & 18 \\
\hline \multicolumn{9}{|l|}{ Region } \\
\hline Ashanti & 19.9 & 16.0 & 83.6 & 79.8 & 32.1 & 22.3 & 2.1 & 287 \\
\hline Central & 19.7 & 9.8 & 91.0 & 84.4 & 29.5 & 19.7 & 0.8 & 122 \\
\hline Oti & 9.8 & 0.0 & 97.6 & 97.6 & 43.9 & 19.5 & 0.0 & 41 \\
\hline Upper East & 18.3 & 17.1 & 90.2 & 86.6 & 40.2 & 36.6 & 1.2 & 82 \\
\hline Volta & 2.2 & 2.2 & 88.8 & 89.9 & 16.9 & 18.0 & 0.0 & 89 \\
\hline \multicolumn{9}{|l|}{ Site } \\
\hline Intervention & 16.9 & 11.9 & 91.5 & 86.4 & 33.9 & 23.7 & 0.0 & 59 \\
\hline Control & 16.4 & 11.9 & 87.2 & 84.0 & 31.0 & 22.8 & 1.4 & 562 \\
\hline Total & 102 & 74 & 544 & 523 & 194 & 142 & 8 & 621 \\
\hline Percent & 16.4 & 11.9 & 87.6 & 84.2 & 31.2 & 22.9 & 1.3 & 100.0 \\
\hline
\end{tabular}




\subsubsection{Training of Health Providers}

Training is critical to providing quality FP services. The percentage distribution of health facilities with a staff who had attended in-service training on the various FP methods or services in the past two years is shown in Tables 4.13a and 4.13b. The highest proportion of health facilities have a CHN (34\%) who attended inservice training in the past two years, which was the highest, followed by midwives (17\%). Regarding inservice training for LARCs, community health nurses were again the highest (38\%), followed by midwives (24\%). 


\section{Table 4. 13a Staff training}

Percentage distribution of staff who have attended in-service training on FP counseling, long-acting reversible contraceptives, and permanent methods in the past two years, FPNHIS 2021

\begin{tabular}{|c|c|c|c|c|c|c|c|c|c|}
\hline & $\begin{array}{l}\text { Doctors: FP } \\
\text { Counseling }\end{array}$ & $\begin{array}{l}\text { Doctors: } \\
\text { LARCs }\end{array}$ & $\begin{array}{l}\text { Doctors: } \\
\text { PMs }\end{array}$ & $\begin{array}{l}\text { Medical/Physician } \\
\text { Assistants: FP } \\
\text { Counseling }\end{array}$ & $\begin{array}{l}\text { Medical/Physician } \\
\text { Assistants: LARCs }\end{array}$ & $\begin{array}{l}\text { PHNs: FP } \\
\text { Counseling }\end{array}$ & $\begin{array}{l}\text { PHNs: } \\
\text { LARCs }\end{array}$ & $\begin{array}{l}\text { Midwives: FP } \\
\text { Counseling }\end{array}$ & $\begin{array}{l}\text { Midwives: } \\
\text { LARCs }\end{array}$ \\
\hline \multicolumn{10}{|l|}{ Type of Facility } \\
\hline Hospital & 4.8 & 3.6 & 8.4 & 3.6 & 1.2 & 3.6 & 7.2 & 12.0 & 30.1 \\
\hline Health Center/Clinic & 1.4 & 0.9 & 0.0 & 7.8 & 3.7 & 6.0 & 6.9 & 22.1 & 31.3 \\
\hline \multicolumn{10}{|l|}{ Community-based Health } \\
\hline Planning Services (CHPS) & 0.0 & 0.0 & 0.0 & 0.3 & 0.0 & 1.7 & 2.0 & 14.0 & 15.7 \\
\hline Maternity Home & 0.0 & 0.0 & 0.0 & 9.5 & 9.5 & 14.3 & 14.3 & 33.3 & 38.1 \\
\hline \multicolumn{10}{|l|}{ Location of facility } \\
\hline Rural & 0.9 & 0.7 & 0.7 & 3.5 & 2.1 & 3.2 & 3.9 & 19.1 & 22.8 \\
\hline Urban & 1.6 & 1.1 & 2.1 & 4.3 & 1.1 & 5.3 & 7.0 & 12.8 & 26.2 \\
\hline \multicolumn{10}{|l|}{ Managing authority } \\
\hline Government & 0.7 & 0.6 & 0.9 & 3.4 & 1.5 & 3.7 & 4.3 & 17.4 & 24.1 \\
\hline Private & 4.5 & 3.0 & 3.0 & 6.0 & 4.5 & 4.5 & 6.0 & 17.9 & 25.4 \\
\hline Mission/Faith-based & 0.0 & 0.0 & 0.0 & 5.6 & 0.0 & 5.6 & 16.7 & 11.1 & 11.1 \\
\hline \multicolumn{10}{|l|}{ Region } \\
\hline Ashanti & 1.0 & 0.3 & 1.4 & 3.8 & 1.7 & 4.5 & 5.9 & 15.3 & 18.5 \\
\hline Central & 0.0 & 0.0 & 0.8 & 4.9 & 1.6 & 2.5 & 2.5 & 15.6 & 23.8 \\
\hline Oti & 0.0 & 0.0 & 0.0 & 0.0 & 0.0 & 0.0 & 2.4 & 19.5 & 26.8 \\
\hline Upper East & 4.9 & 4.9 & 1.2 & 6.1 & 4.9 & 8.5 & 8.5 & 40.2 & 42.7 \\
\hline Volta & 0.0 & 0.0 & 1.1 & 1.1 & 0.0 & 1.1 & 2.2 & 3.4 & 22.5 \\
\hline \multicolumn{10}{|l|}{ Site } \\
\hline FP Pilot district & 0.0 & 0.0 & 0.0 & 1.7 & 1.7 & 3.4 & 1.7 & 22.0 & 27.1 \\
\hline Non-FP Pilot district & 1.2 & 0.9 & 1.2 & 3.9 & 1.8 & 3.9 & 5.2 & 16.7 & 23.5 \\
\hline Total & 7 & 5 & 7 & 23 & 11 & 24 & 30 & 107 & 148 \\
\hline Percent & 1.1 & 0.8 & 1.1 & 3.7 & 1.8 & 3.9 & 4.8 & 17.2 & 23.8 \\
\hline
\end{tabular}




\section{Table 4.13b Staff training}

Percentage distribution of staff who have attended in-service training on FP counseling, long-acting reversible contraceptives, and permanent methods in the past two years, FPNHIS 2021

\begin{tabular}{|c|c|c|c|c|c|c|c|c|}
\hline & $\begin{array}{l}\text { SRNs: FP } \\
\text { Counseling }\end{array}$ & $\begin{array}{l}\text { SRNs: } \\
\text { LARCs }\end{array}$ & $\begin{array}{l}\text { CHNs: FP } \\
\text { Counseling }\end{array}$ & $\begin{array}{l}\text { CHNs: } \\
\text { LARCs }\end{array}$ & $\begin{array}{c}\text { ENs: FP } \\
\text { Counseling }\end{array}$ & $\begin{array}{l}\text { ENs: } \\
\text { LARCs }\end{array}$ & $\begin{array}{c}\text { Pharmacists: FP } \\
\text { Counseling }\end{array}$ & $\begin{array}{c}\text { Total } \\
\text { Number }\end{array}$ \\
\hline \multicolumn{9}{|l|}{ Type of Facility } \\
\hline Hospital & 2.4 & 2.4 & 21.7 & 31.3 & 2.4 & 1.2 & 0.0 & 83 \\
\hline Health Center/Clinic & 8.8 & 6.0 & 35.9 & 41.5 & 6.9 & 5.5 & 0.5 & 217 \\
\hline \multicolumn{9}{|c|}{ Community-based Health Planning Services } \\
\hline Maternity Home & 4.8 & 4.8 & 14.3 & 14.3 & 14.3 & 19.0 & 4.8 & 21 \\
\hline \multicolumn{9}{|l|}{ Location of facility } \\
\hline Rural & 5.8 & 4.4 & 38.2 & 42.6 & 10.4 & 9.2 & 0.5 & 434 \\
\hline Urban & 3.2 & 2.7 & 23.0 & 27.8 & 3.2 & 2.1 & 0.5 & 187 \\
\hline \multicolumn{9}{|l|}{ Managing authority } \\
\hline Government & 4.9 & 3.9 & 35.8 & 40.3 & 8.4 & 7.1 & 0.4 & 536 \\
\hline Private & 6.0 & 3.0 & 17.9 & 22.4 & 7.5 & 9.0 & 1.5 & 67 \\
\hline Mission/Faith-based & 5.6 & 5.6 & 27.8 & 33.3 & 5.6 & 0.0 & 0.0 & 18 \\
\hline \multicolumn{9}{|l|}{ Region } \\
\hline Ashanti & 5.2 & 4.2 & 26.1 & 31.4 & 5.6 & 4.5 & 0.3 & 287 \\
\hline Central & 3.3 & 0.8 & 36.1 & 33.6 & 6.6 & 6.6 & 0.8 & 122 \\
\hline Oti & 2.4 & 0.0 & 39.0 & 46.3 & 4.9 & 4.9 & 0.0 & 41 \\
\hline Upper East & 13.4 & 12.2 & 61.0 & 61.0 & 29.3 & 24.4 & 1.2 & 82 \\
\hline Volta & 0.0 & 1.1 & 27.0 & 41.6 & 1.1 & 1.1 & 0.0 & 89 \\
\hline \multicolumn{9}{|l|}{ Site } \\
\hline FP Pilot district & 3.4 & 3.4 & 37.3 & 40.7 & 8.5 & 6.8 & 0.0 & 59 \\
\hline Non-FP Pilot district & 5.2 & 3.9 & 33.3 & 37.9 & 8.2 & 7.1 & 0.5 & 562 \\
\hline Total & 31 & 24 & 209 & 237 & 51 & 44 & 3 & 621 \\
\hline Percent & 5.0 & 3.9 & 33.7 & 38.2 & 8.2 & 7.1 & 0.5 & 100 \\
\hline
\end{tabular}




\subsubsection{Availability of Family Planning Commodities}

Availability of FP commodities is critical if the inclusion of FP into the NHI benefits package can be scaled up. Table 4.14 shows the percentage distribution of the various FP commodities/services that are always available in health facilities by background characteristics.

In all, more than 9 in 10 (95\%) of the health facilities indicated that the 3-month injectable is always available, which is the highest followed by implants (90\%), oral contraceptives pills (74\%), and the least available contraceptive is the female condom (4\%). Availability of PMs services is low as 8 percent of the health facilities indicated female sterilization services are always available and 5 percent indicated that male sterilization services are always available. Additionally, almost 2 in 10 health facilities mentioned that emergency contraception is always available.

Availability of the 3-month injectable is highest in health centers/clinics (99\%) and lowest in maternity homes (91\%). Differences in the availability of the 3-month injectable across regions, rural-urban locations, site, and managing authority is minimal. With respect to implants, the second most common FP method, at least 8 in 10 health facilities indicated it is always available across background characteristics. However, less than 1 in 10 health facilities indicated that female condoms are always available. 
Table 4. 14 Availability of family planning commodities/services

Percentage distribution of health facilities with FP commodities/services that are always available by background characteristics, FPNHIS 2021

\begin{tabular}{|c|c|c|c|c|c|c|c|c|c|c|c|}
\hline 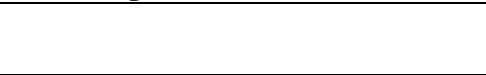 & $\begin{array}{l}\text { Male } \\
\text { condoms }\end{array}$ & $\begin{array}{l}\text { Female } \\
\text { Condoms }\end{array}$ & $\begin{array}{c}\text { Oral } \\
\text { contraceptives }\end{array}$ & $\begin{array}{c}\text { 1-month } \\
\text { injectables }\end{array}$ & $\begin{array}{c}\text { 3-months } \\
\text { injectables }\end{array}$ & Implants & IUDs & $\begin{array}{l}\text { Female } \\
\text { Sterilization }\end{array}$ & $\begin{array}{l}\text { Male } \\
\text { Sterilization }\end{array}$ & $\begin{array}{l}\text { Emergency } \\
\text { contraceptives }\end{array}$ & $\begin{array}{l}\text { Total } \\
\text { number }\end{array}$ \\
\hline \multicolumn{12}{|l|}{ Type of Facility } \\
\hline Hospital & 61.4 & 3.6 & 77.1 & 33.7 & 91.6 & 86.7 & 65.1 & 51.8 & 32.5 & 37.3 & 83 \\
\hline Health Center/Clinic & 67.6 & 4.2 & 80.1 & 29.6 & 98.6 & 94.0 & 31.9 & 3.7 & 1.9 & 13.9 & 216 \\
\hline \multicolumn{12}{|l|}{ Community-based Health Planning } \\
\hline Services (CHPS) & 62.3 & 4.0 & 70.0 & 34.0 & 93.7 & 89.7 & 10.3 & 0.0 & 0.0 & 14.0 & 300 \\
\hline Maternity Home & 52.4 & 0.0 & 57.1 & 28.6 & 90.5 & 76.2 & 52.4 & 0.0 & 0.0 & 19.0 & 21 \\
\hline \multicolumn{12}{|l|}{ Location of facility } \\
\hline Rural & 65.4 & 3.2 & 72.8 & 32.7 & 94.7 & 92.6 & 17.1 & 2.1 & 1.6 & 13.6 & 434 \\
\hline Urban & 59.7 & 5.4 & 76.9 & 31.2 & 95.7 & 84.9 & 48.9 & 22.6 & 12.9 & 25.8 & 186 \\
\hline \multicolumn{12}{|l|}{ Managing authority } \\
\hline Government & 65.6 & 4.3 & 75.9 & 33.1 & 95.7 & 92.5 & 23.6 & 5.8 & 4.3 & 15.9 & 535 \\
\hline Private & 49.3 & 0.0 & 58.2 & 26.9 & 89.6 & 73.1 & 49.3 & 23.9 & 9.0 & 23.9 & 67 \\
\hline Mission/Faith-based & 61.1 & 5.6 & 77.8 & 27.8 & 94.4 & 88.9 & 33.3 & 22.2 & 11.1 & 33.3 & 18 \\
\hline \multicolumn{12}{|l|}{ Region } \\
\hline Ashanti & 55.2 & 2.1 & 76.9 & 19.2 & 95.8 & 87.1 & 26.9 & 12.2 & 6.6 & 22.7 & 286 \\
\hline Central & 67.2 & 3.3 & 80.3 & 24.6 & 94.3 & 95.1 & 38.5 & 4.9 & 3.3 & 17.2 & 122 \\
\hline Oti & 75.6 & 4.9 & 61.0 & 51.2 & 95.1 & 92.7 & 34.1 & 9.8 & 4.9 & 2.4 & 41 \\
\hline Upper East & 72.0 & 11.0 & 63.4 & 48.8 & 93.9 & 87.8 & 11.0 & 2.4 & 2.4 & 19.5 & 82 \\
\hline Volta & 73.0 & 3.4 & 71.9 & 60.7 & 94.4 & 95.5 & 20.2 & 4.5 & 4.5 & 4.5 & 89 \\
\hline \multicolumn{12}{|l|}{ Site } \\
\hline FP Pilot district & 74.6 & 1.7 & 78.0 & 39.0 & 93.2 & 91.5 & 28.8 & 5.1 & 3.4 & 16.9 & 59 \\
\hline Non-FP Pilot district & 62.6 & $\begin{array}{l}1.1 \\
4.1\end{array}$ & 73.6 & 31.6 & 95.2 & 90.2 & 26.4 & 8.6 & $\begin{array}{l}5.4 \\
5.2\end{array}$ & 17.3 & 561 \\
\hline Total & 395 & 24 & 459 & 200 & 589 & 560 & 165 & 51 & 31 & 107 & 620 \\
\hline Percent & 63.7 & 3.9 & 74.0 & 32.3 & 95.0 & 90.3 & 26.6 & 8.2 & 5.0 & 17.3 & 100.0 \\
\hline
\end{tabular}

Note: 1 missing case 


\subsubsection{Commodity Stock-Outs}

Contraceptive stock-outs in health facilities have implications for FP service delivery. In Ghana, stock-out of FP commodities have been attributed to non-usable stocks such as expiration, damages, quarantined commodities for regulatory purposes, and shortages because of the non-timely request of commodities, inadequate or limited commodity quantities received by health facilities.

Table 4.15 shows the proportion of health facilities with no stock-outs of specific FP methods in three months before the survey. A high proportion of facilities reported no stock-outs for implants (91\%), injectables (90\%), oral contraceptive pills (79\%), male condoms (72\%), IUD (57\%), and emergency contraceptives (34\%). Comparing by type of facility, a high proportion of health centers and clinics reported no stock-outs of implants (92\%). Implants remained the commodity with which a high proportion of facilities in rural and urban areas, across various managing authorities, regions, and study sites reporting no stock-outs in the three months before the survey. 
Table 4.15 Family planning commodity stock-outs

Percentage distribution of health facilities with no stock-outs of specific FP method in the past 3 months, FPNHIS 2021

\begin{tabular}{|c|c|c|c|c|c|c|c|c|c|c|c|c|c|c|c|c|}
\hline & $\begin{array}{c}\text { Male } \\
\text { condom }\end{array}$ & $\begin{array}{c}\text { Total } \\
\text { number }\end{array}$ & $\begin{array}{l}\text { Female } \\
\text { condom }\end{array}$ & $\begin{array}{c}\text { Total } \\
\text { number }\end{array}$ & $\begin{array}{c}\text { Oral } \\
\text { contraceptives } \\
\end{array}$ & $\begin{array}{c}\text { Total } \\
\text { number }\end{array}$ & Injectables & $\begin{array}{c}\text { Total } \\
\text { number }\end{array}$ & Implants & $\begin{array}{c}\text { Total } \\
\text { number }\end{array}$ & IUD & $\begin{array}{c}\text { Total } \\
\text { number }\end{array}$ & $\begin{array}{c}\text { Emergency } \\
\text { contraceptives }\end{array}$ & $\begin{array}{c}\text { Total } \\
\text { number }\end{array}$ & $\begin{array}{l}\text { Natural } \\
\text { methods }\end{array}$ & $\begin{array}{c}\begin{array}{c}\text { Total } \\
\text { number }\end{array} \\
\end{array}$ \\
\hline \multicolumn{17}{|l|}{ Type of Facility } \\
\hline Hospital & 75.6 & 82 & 9.9 & 71 & 84.1 & 82 & 83.1 & 83 & 87.8 & 82 & 81.9 & 72 & 46.5 & 71 & 57.0 & 79 \\
\hline Health Center/Clinic & 76.1 & 213 & 11.6 & 155 & 83.1 & 213 & 91.2 & 216 & 92.1 & 216 & 61.3 & 124 & 32.9 & 152 & 59.7 & 181 \\
\hline Community-based & 68.9 & 293 & 10.6 & 208 & 75.3 & 291 & 90.6 & 299 & 91.6 & 296 & 32.0 & 97 & 31.2 & 199 & 62.0 & 234 \\
\hline \multirow{2}{*}{\multicolumn{17}{|c|}{ Health Planning }} \\
\hline \multicolumn{8}{|l|}{ Services (CHPS) } & & & & & & & & & \\
\hline Maternity Home & 50.0 & 16 & 18.2 & 11 & 61.1 & 18 & 81.0 & 21 & 83.3 & 18 & 70.6 & 17 & 30.8 & 13 & 42.9 & 14 \\
\hline \multicolumn{17}{|l|}{ Location of facility } \\
\hline Rural & 73.5 & 426 & 9.4 & 309 & 78.1 & 425 & 90.8 & 433 & 91.6 & 430 & 44.5 & 173 & 29.5 & 292 & 60.5 & 347 \\
\hline Urban & 68.0 & 178 & 14.7 & 136 & 80.4 & 179 & 86.6 & 186 & 89.6 & 182 & 73.7 & 137 & 44.1 & 143 & 58.4 & 161 \\
\hline \multicolumn{17}{|l|}{ Managing authority } \\
\hline Government & 74.0 & 526 & 10.7 & 382 & 80.9 & 524 & 90.1 & 534 & 92.7 & 531 & 56.1 & 244 & 31.8 & 368 & 62.4 & 433 \\
\hline Private & 51.7 & 60 & 12.0 & 50 & 56.5 & 62 & 85.1 & 67 & 76.2 & 63 & 63.0 & 54 & 43.4 & 53 & 33.3 & 57 \\
\hline Mission/Faith-based & 77.8 & 18 & 15.4 & 13 & 94.4 & 18 & 88.9 & 18 & 94.4 & 18 & 58.3 & 12 & 64.3 & 14 & 83.3 & 18 \\
\hline \multicolumn{17}{|l|}{ Region } \\
\hline Ashanti & 62.9 & 278 & 8.5 & 188 & 79.7 & 281 & 87.7 & 285 & 87.5 & 281 & 55.0 & 151 & 36.5 & 208 & 51.4 & 216 \\
\hline Central & 75.2 & 117 & 10.3 & 87 & 86.2 & 116 & 87.7 & 122 & 96.6 & 119 & 68.9 & 74 & 40.0 & 80 & 64.4 & 104 \\
\hline Oti & 87.8 & 41 & 5.7 & 35 & 82.9 & 41 & 95.1 & 41 & 95.1 & 41 & 81.3 & 16 & 18.8 & 16 & 69.4 & 36 \\
\hline Upper East & 80.0 & 80 & 21.9 & 64 & 71.8 & 78 & 91.5 & 82 & 91.5 & 82 & 30.0 & 40 & 51.6 & 62 & 88.9 & 72 \\
\hline Volta & 80.7 & 88 & 11.3 & 71 & 70.5 & 88 & 93.3 & 89 & 92.1 & 89 & 65.5 & 29 & 8.7 & 69 & 46.3 & 80 \\
\hline \multicolumn{17}{|l|}{ Site } \\
\hline FP Pilot district & 75.4 & 57 & 17.1 & 35 & 83.6 & 55 & 84.7 & 59 & 94.9 & 59 & 62.1 & 29 & 50.0 & 36 & 77.6 & 49 \\
\hline Non-FP Pilot district & 71.5 & 547 & 10.5 & 410 & 78.3 & 549 & 90.0 & 560 & 90.6 & 553 & 56.9 & 281 & 32.8 & 399 & 58.0 & 459 \\
\hline Total & 434 & 604 & 49 & 445 & 476 & 604 & 554 & 619 & 557 & 612 & 178 & 310 & 149 & 435 & 304 & 508 \\
\hline Percent & 71.9 & 100.0 & 11.0 & 100.0 & 78.8 & 100.0 & 89.5 & 100.0 & 91.0 & 100.0 & 57.4 & 100.0 & 34.3 & 100.0 & 59.8 & 100.0 \\
\hline
\end{tabular}

Note: Natural methods include cycle beads 


\subsubsection{Availability of Family Planning Equipment and Supplies}

Family planning equipment and supplies are crucial to ensuring the provision of quality FP services. Table 4.16 presents data on the percentage of health facilities with essential FP equipment and supplies in the study facilities according to facility background characteristics. At least $90 \%$ of facilities in the study regions have almost half (12 out of 26) of the essential FP equipment and supplies available and in working condition in the health facilities. The tenaculum is the least available essential FP equipment available and in working condition in the health facilities (38\%).

\begin{tabular}{|c|c|c|}
\hline & \multicolumn{2}{|c|}{$\begin{array}{l}\text { Have equipment or supplies available } \\
\text { and in working condition }\end{array}$} \\
\hline & Percent & Number \\
\hline Spotlight source (flashlight or examination light) & 40.3 & 250 \\
\hline Couch/bed and stool for examination \& procedures & 86.5 & 536 \\
\hline Table/trolley for tray setup & 73.9 & 458 \\
\hline Blood pressure apparatus & 91.8 & 569 \\
\hline Stethoscope & 87.1 & 540 \\
\hline Weighing scale & 94.8 & 588 \\
\hline Sterile needle and syringe & 97.9 & 607 \\
\hline Armrest for Implant insertion & 40.5 & 251 \\
\hline Vaginal speculum & 49.0 & 304 \\
\hline Tenaculum & 38.2 & 237 \\
\hline Sponge Holding forceps & 70.8 & 439 \\
\hline kidney Dishes & 90.5 & 561 \\
\hline Curved Mosquito Artery Forceps & 69.8 & 433 \\
\hline Gallipots & 87.1 & 540 \\
\hline Uterine Sound & 39.4 & 244 \\
\hline Alligator Forceps & 44.5 & 276 \\
\hline Soap for handwashing & 98.7 & 612 \\
\hline Single-use towel/Disposable tissue & 92.4 & 573 \\
\hline Flowing water or veronica bucket for handwashing & 97.9 & 607 \\
\hline $\begin{array}{l}\text { Decontamination solution for clinical equipment (chlorine) with } 0.5 \\
\text { concentration }\end{array}$ & 92.4 & 573 \\
\hline Plastic buckets for decontamination & 91.8 & 569 \\
\hline Disposable gloves/Sterile gloves & 90.0 & 558 \\
\hline Safety Box / Yellow Box / Sharps Box & 98.6 & 611 \\
\hline Waste Bin (hard sided, pedal operated) & 92.1 & 571 \\
\hline Lining for waste bin & 64.8 & 402 \\
\hline Antiseptic (e.g., Savlon \& lodine) & 88.9 & 551 \\
\hline
\end{tabular}

Note: 1 missing case 


\title{
5 NATIONAL HEALTH INSURANCE BENEFITS PACKAGE
}

\author{
Highlights: \\ - Majority (91\%) of the health facilities provide health services under the \\ NHIS. \\ - Health facilities that were not providing health services under the NHIS \\ attributed it to not being credentialled (66\%). \\ - Overall, 79 percent of health facilities indicated that they had a staff \\ trained on NHI claims processing. \\ - Among health facilities providing health services under the NHIS, 7 \\ percent were providing FP services under the scheme. \\ - In districts where the out-of-pocket cost removal for FP services \\ intervention was implemented 58 percent of health facilities continued \\ providing services as directed. \\ - Among health facilities currently not providing FP services under the NHIS, \\ 94 percent were willing to provide services under the NHIS.
}

The FPNHIS was designed to assess health facilities' provision of services under the NHI benefits package as well as the provision of FP services under the NHIS. These topics are critical to policymakers as they consider the inclusion of FP into the national health insurance benefits package.

\subsection{Provision of Health Services Under the National Health Insurance Benefits Package}

Including FP services into the NHIS requires that health facilities be credentialled to provide health services under the scheme. Health facilities providing services under the NHIS will serve as the platform for the scaleup. Table 5.1 shows the percentage distribution of health facilities providing health services under the NHI benefits package, as well as the percentage distribution of reasons why some health facilities are unable to provide services under the scheme.

Approximately, 91 percent of health facilities provide health services under the NHIS. The percentage of health facilities providing health services under the NHIS decreased from 96 percent among hospitals and health centers/clinics to 62 percent among maternity homes. Provision of health services under the NHIS is higher in rural areas (92\%) compared to urban areas (87\%). All mission/faith-based (100\%) and 79 percent of private health facilities provide health services under the NHIS. The provision of health services under the scheme is almost universal in Volta (99\%), 92 percent in Central, and 87 percent in the Upper East regions, which is the lowest. Provision of health services under the NHIS is one percentage point higher in the nonFP Pilot districts (91\%) compared to the FP Pilot districts (90\%).

Among health facilities that were not providing health services under the NHIS, 66 percent of them indicated that their facility is not credentialled, which is the highest followed by 5 percent indicating that it is a result of delays in provider reimbursement. 
Table 5. 1 Provision of health services under the national health insurance scheme

Percentage distribution of health facilities providing health services under the national health insurance scheme, and percentage distribution of reasons why facilities are unable to provide health services under the national health insurance scheme by background characteristics, FPNHIS 2021

\begin{tabular}{|c|c|c|c|c|c|c|c|c|c|c|c|}
\hline & \multirow{2}{*}{$\begin{array}{l}\text { Provide } \\
\text { health } \\
\text { services } \\
\text { under the } \\
\text { NHIS }\end{array}$} & \multirow[b]{2}{*}{$\begin{array}{c}\text { Total } \\
\text { number }\end{array}$} & \multicolumn{7}{|c|}{ Reasons why facilities are unable to provide health services under the National Health Insurance Scheme: } & \multirow[b]{2}{*}{ Other } & \multirow[b]{2}{*}{$\begin{array}{l}\text { Total } \\
\text { numbe }\end{array}$} \\
\hline & & & $\begin{array}{l}\text { Facility is not } \\
\text { credentialled }\end{array}$ & $\begin{array}{c}\text { Inactive } \\
\text { credentialling }\end{array}$ & $\begin{array}{l}\text { Lack of } \\
\text { training } \\
\text { in NHIA } \\
\text { SOPs }\end{array}$ & $\begin{array}{c}\text { Lack of } \\
\text { equipment }\end{array}$ & $\begin{array}{c}\text { Management } \\
\text { issues }\end{array}$ & $\begin{array}{c}\text { Delays in } \\
\text { provider } \\
\text { reimbursement }\end{array}$ & $\begin{array}{l}\text { Facility not } \\
\text { interested }\end{array}$ & & \\
\hline \multicolumn{12}{|l|}{ Type of Facility } \\
\hline Hospital & 96.4 & 83 & 66.7 & 33.3 & 66.7 & 0.0 & 33.3 & 33.3 & 0.0 & 0.0 & 3 \\
\hline Health Center/Clinic & 95.9 & 217 & 77.8 & 0.0 & 11.1 & 11.1 & 22.2 & 0.0 & 11.1 & 0.0 & 9 \\
\hline Community-based & 87.3 & 300 & 68.4 & 7.9 & 31.6 & 15.8 & 15.8 & 0.0 & 2.6 & 13.2 & 38 \\
\hline \multicolumn{12}{|l|}{ Health Planning } \\
\hline Maternity Home & 61.9 & 21 & 37.5 & 12.5 & 0.0 & 12.5 & 0.0 & 25.0 & 37.5 & 0.0 & 8 \\
\hline \multicolumn{12}{|l|}{ Location of facility } \\
\hline Rural & 92.4 & 434 & 72.7 & 12.1 & 30.3 & 15.2 & 18.2 & 3.0 & 6.1 & 9.1 & 33 \\
\hline Urban & 86.6 & 187 & 56.0 & 4.0 & 20.0 & 12.0 & 12.0 & 8.0 & 12.0 & 8.0 & 25 \\
\hline \multicolumn{12}{|l|}{ Managing authority } \\
\hline Government & 91.8 & 536 & 68.2 & 6.8 & 31.8 & 13.6 & 18.2 & 0.0 & 2.3 & 11.4 & 44 \\
\hline Private & 79.1 & 67 & 57.1 & 14.3 & 7.1 & 14.3 & 7.1 & 21.4 & 28.6 & 0.0 & 14 \\
\hline Mission/Faith-based & 100.0 & 18 & 0.0 & 0.0 & 0.0 & 0.0 & 0.0 & 0.0 & 0.0 & 0.0 & 0 \\
\hline \multicolumn{12}{|l|}{ Region } \\
\hline Ashanti & 88.9 & 287 & 62.5 & 6.3 & 25.0 & 18.8 & 18.8 & 3.1 & 3.1 & 12.5 & 32 \\
\hline Central & 91.8 & 122 & 40.0 & 10.0 & 0.0 & 10.0 & 0.0 & 20.0 & 30.0 & 10.0 & 10 \\
\hline Oti & 90.2 & 41 & 100.0 & 0.0 & 50.0 & 0.0 & 25.0 & 0.0 & 0.0 & 0.0 & 4 \\
\hline Upper East & 86.6 & 82 & 90.9 & 18.2 & 45.5 & 9.1 & 9.1 & 0.0 & 9.1 & 0.0 & 11 \\
\hline Volta & 98.9 & 89 & 0.0 & 0.0 & 0.0 & 0.0 & 100.0 & 0.0 & 0.0 & 0.0 & 1 \\
\hline \multicolumn{12}{|l|}{ Site } \\
\hline FP Pilot district & 89.8 & 59 & 100.0 & 0.0 & 16.7 & 0.0 & 16.7 & 0.0 & 0.0 & 0.0 & 6 \\
\hline Non-FP Pilot district & 90.7 & 562 & 61.5 & 9.6 & 26.9 & 15.4 & 15.4 & 5.8 & 9.6 & 9.6 & 52 \\
\hline Total & 563 & 621 & 38 & 5 & 15 & 8 & 9 & 3 & 5 & 5 & 58 \\
\hline Percent & 90.7 & 100.0 & 65.5 & 8.6 & 25.9 & 13.8 & 15.5 & 5.2 & 8.6 & 8.6 & 100.0 \\
\hline
\end{tabular}




\subsection{Training on National Health Insurance Scheme Claims}

Key to the timely processing of claims is the ability of health facility staff to correctly process and submit claims to the NHIA. Regardless of whether a health facility is providing health services under the NHIS or not, health facilities were asked whether a staff member in the facility has received training on the process of submitting NHIS claims. Table 5.2 shows the percentage distribution of health facilities with a staff trained on the NHIS claims processing. The results reveal that 79 percent of the health facilities have staff who

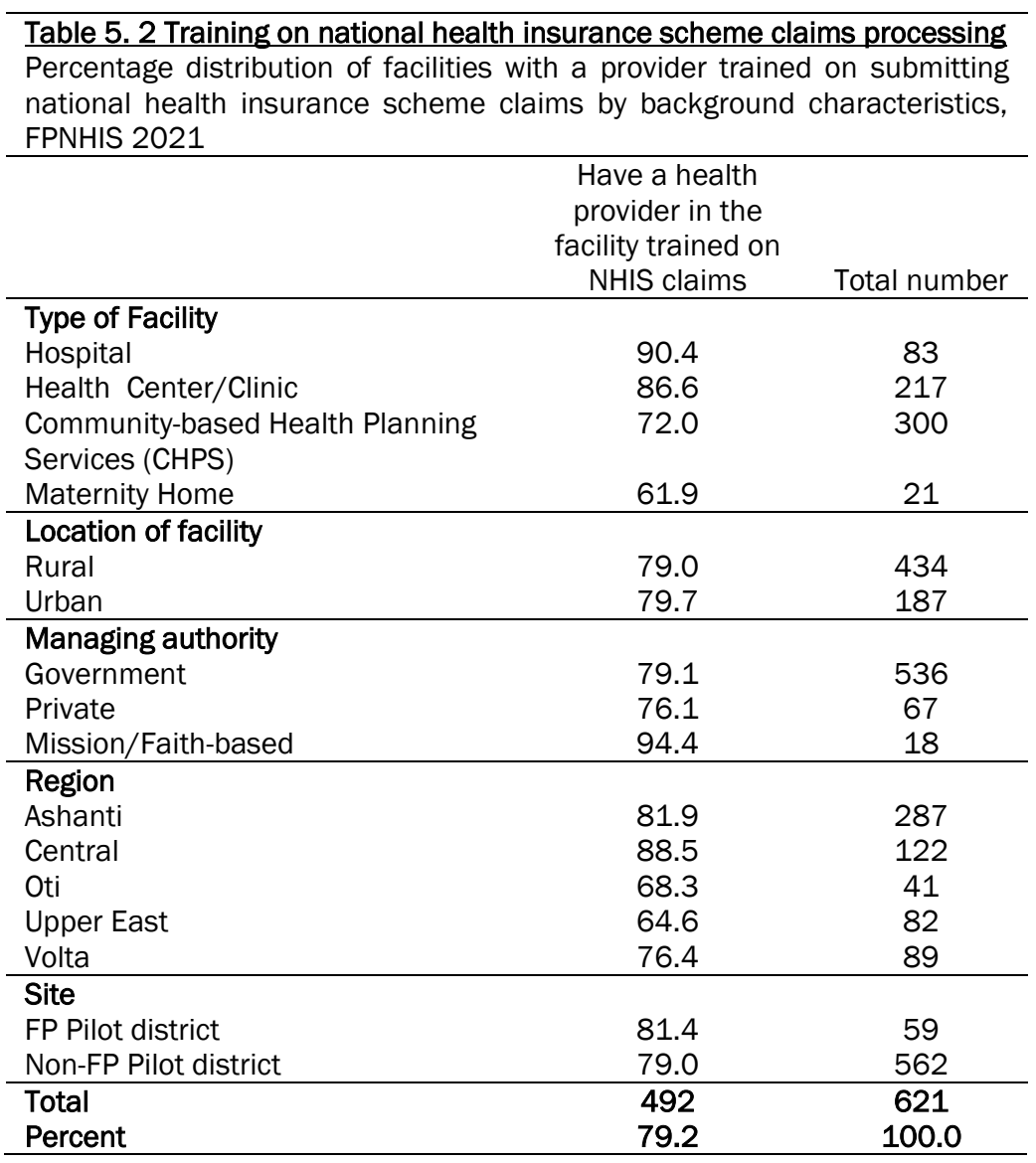
received training on submitting NHIS claims.

Majority of hospitals (90\%) have a staff member trained in claims processing, 87 percent of health centers/clinics, 72 percent of community-based health planning services, and 62 percent of maternity homes have a staff member trained in claims processing. Eighty percent of health facilities in urban areas have a staff member trained in claims processing.

Health facilities managed by mission/faith-based organizations have the highest percentage (94\%) indicating they have a staff trained in NHIS claims processing, 79 percent of government institutions, and 76 percent of private health facilities also do. Across the five study regions, the highest percentage of health facilities have processing was in Central region (89\%), followed by Ashanti (82\%), Volta (76\%) regions, and lowest among health facilities in the Upper East region (65\%). Health facilities with a staff trained in claims processing are 2.4 percentage points higher in the FP Pilot districts compared to the non-FP Pilot districts (81\% versus $79 \%$ ).

\subsection{Inclusion of Family Planning into the National Health Insurance Scheme Package}

As indicated earlier, the inclusion of FP into the NHIS was piloted in selected districts. However, the out-ofpocket cost removal intervention was implemented in seven districts. This section analyzes the provision of FP within the NHIS package, and the willingness of health facilities to provide FP services under the NHI package.

\subsubsection{Provision of Family Planning Within the National Health Insurance Scheme Package}

In this survey, data were collected on the provision of FP under the NHIS. Health facilities that indicated they were providing health services under the national health insurance scheme were also asked if they provide FP services under the scheme. At the end of the FP Pilot intervention in the year 2020, health facilities in the intervention districts which received the out-of-pocket cost removal intervention were asked to continue providing FP services under the scheme. Hence, further analysis was also conducted to ascertain if health facilities continued to provide FP services under the NHIS package. 
Table 5.3 shows the distribution of health facilities providing FP under the NHIS, and the percentage distribution of health facilities in the seven FP Pilot districts that received out-of-pocket removal intervention that provides FP services under the NHIS.

Less than 1 in 10 (7\%) of the health facilities provide FP services under the NHIS package. This varies from 23 percent among maternity homes, which is the highest to 6 percent among health centers/clinics which is the lowest. While 8 percent of health facilities in urban areas indicate they provide FP services under the NHIS, 7 percent of health facilities in rural areas do. Private health facilities $(13 \%)$ are more likely to provide FP services under the NHIS compared to government $(7 \%)$ and mission/faith-based $(0 \%)$ health facilities.

The findings reveal that health facilities in the Upper East region (23\%) are more likely to provide FP services under the national health insurance scheme compared to other regions. More than half $(53 \%)$ of health facilities in the FP Pilot districts provide FP services under the national health insurance scheme compared to 2 percent of the health facilities in the non-FP Pilot districts.

Specific to the seven FP Pilot districts that received the out-of-pocket cost removal intervention, 58 percent of the health facilities provide FP services under the NHIS. FP service provision under the NHIS was universal in maternity homes, 75 percent among hospitals, 67 percent among health centers/clinics, and 48 percent among community-based health planning services. The results further reveal that the provision of FP services under the national health insurance scheme is higher in urban areas (67\%) compared to rural areas (54\%). 
Table 5. 3 Provision of family planning under the national health insurance scheme package

Percentage distribution of health facilities providing FP services under the national health insurance scheme package, and percentage distribution of health facilities in only the FP Pilot districts providing FP services under the national health insurance scheme package by background characteristics, FPNHIS 2021

\begin{tabular}{|c|c|c|c|c|}
\hline & $\begin{array}{l}\text { Health facility provides FP services } \\
\text { under the NHIS package }\end{array}$ & $\begin{array}{c}\text { Total } \\
\text { number }\end{array}$ & $\begin{array}{l}\text { FP Pilot districts that received the out-of- } \\
\text { pocket cost removal for FP services: Health } \\
\text { facility provides FP services under the NHIS } \\
\text { package }\end{array}$ & $\begin{array}{c}\text { Total } \\
\text { number }\end{array}$ \\
\hline \multicolumn{5}{|l|}{ Type of Facility } \\
\hline Hospital & 7.5 & 80 & 75.0 & 4 \\
\hline Health Center/Clinic & 5.8 & 208 & 66.7 & 12 \\
\hline Community-based Health Planning Services (CHPS) & 7.3 & 262 & 48.3 & 29 \\
\hline Maternity Home & 23.1 & 13 & 100.0 & 2 \\
\hline \multicolumn{5}{|l|}{ Location of facility } \\
\hline Rural & 6.7 & 401 & 54.3 & 35 \\
\hline Urban & 8.0 & 162 & 66.7 & 12 \\
\hline \multicolumn{5}{|l|}{ Managing authority } \\
\hline Government & 6.7 & 492 & 57.1 & 42 \\
\hline Private & 13.2 & 53 & 60.0 & 5 \\
\hline Mission/Faith-based & 0.0 & 18 & 0.0 & 0 \\
\hline \multicolumn{5}{|l|}{ Region } \\
\hline Ashanti & 4.3 & 255 & 45.5 & 11 \\
\hline Central & 8.0 & 112 & 72.7 & 11 \\
\hline Oti & 2.7 & 37 & na & na \\
\hline Upper East & 22.5 & 71 & 50.0 & 22 \\
\hline Volta & 3.4 & 88 & 100.0 & 3 \\
\hline \multicolumn{5}{|l|}{ Site } \\
\hline FP Pilot district & 52.8 & 53 & na & na \\
\hline Non-FP Pilot district & 2.4 & 510 & na & na \\
\hline Total & 40 & 563 & 27 & 47 \\
\hline Percent & 7.1 & 100.0 & 57.5 & 100.0 \\
\hline
\end{tabular}




\subsubsection{Willingness to Provide Family Planning within the National Health Insurance Scheme Package}

The FPNHIS assessed the willingness of health facilities to provide FP under the NHIS. The analysis was done among health facilities currently not providing FP services under the NHIS. They were asked if the health facility was willing to provide FP services under the NHIS package.

Table 5.4 shows the percentage of health facilities that are willing to provide FP services under the NHIS package and the reasons why some health facilities are not willing to provide FP services under the NHIS package. Overall, 94 percent of the health facilities are willing to provide FP services under the NHIS package.

The percentage of health facilities willing to provide FP services under the NHIS package is highest among CHPS compounds (98\%) and lowest among maternity homes (67\%). By rural-urban location, it is higher among rural health facilities (96\%), the government managed facilities (95\%), facilities in the Volta (99\%), and Upper East (98\%) regions. All health facilities in FP Pilot districts are willing to provide FP under the NHIS. A higher proportion of health facilities that are not willing to provide FP under the NHIS cited delays in provider reimbursement (60\%) as the reason. 
Table 5. 4 Willingness of health facilities to provide family planning services under the national health insurance scheme

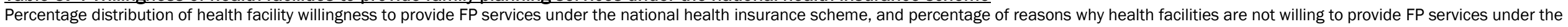
national health insurance scheme by background characteristics, FPNHIS 2021.

\begin{tabular}{|c|c|c|c|c|c|c|c|c|c|c|c|c|}
\hline & & & Why is the facil & ot willing to pro & e FP servi & under the $\mathrm{N}$ & al Health Insurance Sc & & & & & \\
\hline & $\begin{array}{l}\text { willing to } \\
\text { provide FP } \\
\text { services } \\
\text { under the } \\
\text { NHIS }\end{array}$ & $\begin{array}{c}\text { Total } \\
\text { number }\end{array}$ & $\begin{array}{l}\text { Facility is not } \\
\text { credentialled }\end{array}$ & $\begin{array}{c}\text { Inactive } \\
\text { credentialling }\end{array}$ & $\begin{array}{c}\text { Lack of } \\
\text { trained } \\
\text { health } \\
\text { workers }\end{array}$ & $\begin{array}{l}\text { Lack of } \\
\text { equipment }\end{array}$ & Management issues & $\begin{array}{c}\text { FP not } \\
\text { included } \\
\text { in NHIS } \\
\text { benefits } \\
\text { package }\end{array}$ & $\begin{array}{c}\text { Delays in provider } \\
\text { reimbursement }\end{array}$ & $\begin{array}{l}\text { Facility not } \\
\text { interested }\end{array}$ & Other & $\begin{array}{c}\text { Total } \\
\text { number }\end{array}$ \\
\hline Type of Facility & & & & & & & & & & & & \\
\hline Hospital & 90.9 & 77 & 0.0 & 0.0 & 14.3 & 0.0 & 0.0 & 14.3 & 71.4 & 14.3 & 0.0 & 7 \\
\hline Health Center/Clinic & 92.7 & 205 & 0.0 & 6.7 & 13.3 & 13.3 & 20.0 & 46.7 & 60.0 & 26.7 & 0.0 & 15 \\
\hline Community-based & 97.5 & 279 & 0.0 & 0.0 & 0.0 & 0.0 & 0.0 & 42.9 & 71.4 & 42.9 & 14.3 & 7 \\
\hline $\begin{array}{l}\text { Health Planning } \\
\text { Services (CHPS) }\end{array}$ & & & & & & & & & & & & \\
\hline Maternity Home & 66.7 & 18 & 0.0 & 16.7 & 0.0 & 0.0 & 0.0 & 33.3 & 33.3 & 66.7 & 0.0 & 6 \\
\hline Location of facility & & & & & & & & & & & & \\
\hline Rural & 95.8 & 405 & 0.0 & 5.9 & 11.8 & 11.8 & 11.8 & 35.3 & 64.7 & 41.2 & 5.9 & 17 \\
\hline Urban & 89.7 & 174 & 0.0 & 5.6 & 5.6 & 0.0 & 5.6 & 38.9 & 55.6 & 27.8 & 0.0 & 18 \\
\hline Managing authority & & & & & & & & & & & & \\
\hline Government & 95.2 & 501 & 0.0 & 4.2 & 8.3 & 8.3 & 12.5 & 41.7 & 66.7 & 29.2 & 4.2 & 24 \\
\hline Private & 85.0 & 60 & 0.0 & 11.1 & 11.1 & 0.0 & 0.0 & 22.2 & 33.3 & 55.6 & 0.0 & 9 \\
\hline Mission/Faith-based & 88.9 & 18 & 0.0 & 0.0 & 0.0 & 0.0 & 0.0 & 50.0 & 100.0 & 0.0 & 0.0 & 2 \\
\hline Region & & & & & & & & & & & & \\
\hline Ashanti & 90.6 & 276 & 0.0 & 3.8 & 7.7 & 0.0 & 3.8 & 38.5 & 69.2 & 30.8 & 3.8 & 26 \\
\hline Central & 94.7 & 113 & 0.0 & 16.7 & 0.0 & 16.7 & 0.0 & 33.3 & 33.3 & 66.7 & 0.0 & 6 \\
\hline Oti & 97.5 & 40 & 0.0 & 0.0 & 0.0 & 0.0 & 0.0 & 0.0 & 100.0 & 0.0 & 0.0 & 1 \\
\hline Upper East & 98.4 & 64 & 0.0 & 0.0 & 100.0 & 100.0 & 100.0 & 100.0 & 0.0 & 0.0 & 0.0 & 1 \\
\hline Volta & 98.8 & 86 & 0.0 & 0.0 & 0.0 & 0.0 & 100.0 & 0.0 & 0.0 & 0.0 & 0.0 & 1 \\
\hline Site & & & & & & & & & & & & \\
\hline FP Pilot district & 100.0 & 30 & 0.0 & 0.0 & 0.0 & 0.0 & 0.0 & 0.0 & 0.0 & 0.0 & 0.0 & 0 \\
\hline Non-FP Pilot district & 93.6 & 549 & 0.0 & 5.7 & 8.6 & 5.7 & 8.6 & 37.1 & 60.0 & 34.3 & 2.9 & 35 \\
\hline Total & 544 & 579 & 0 & 2 & 3 & 2 & 3 & 13 & 21 & 12 & 1 & 35 \\
\hline Percent & 94.0 & 100.0 & 0.0 & 5.7 & 8.6 & 5.7 & 8.6 & 37.1 & 60.0 & 34.3 & 2.9 & 100.0 \\
\hline
\end{tabular}

Note: 2 missing cases 


\title{
6 SUPPLY CHAIN AND LOGISTICS
}

\author{
Highlights: \\ - Overall, 6 in 10 (60\%) health facilities have a staff trained in \\ logistics management. \\ - More than 90 percent of health facilities use stock cards/bin \\ cards/inventory cards to manage FP commodities. \\ - Ninety-seven percent of health facilities reported logistics data to \\ the higher authority monthly. \\ - In general, 86 percent of health facilities received their \\ commodities one month or less after requesting. \\ - Seventy percent of health facilities determine their family planning \\ re-supply quantities
}

The FPNHIS assessed supply chain and associated logistics for FP service provision. Health facilities were asked about commodity stock keeping, supply and logistics, reporting logistics data to the higher-level authority, and supply of FP commodities. These are very important pieces of information as the country plans to scale-up the inclusion of FP into the NHIS package. The information in this chapter will help decisionmakers to understand the flow of FP commodities and help the NHIA to work with health facilities on the systems to adapt for the collation of FP service data for claims processing.

\subsection{Family Planning Commodities Stock Keeping, Supply, and Logistics}

This section presents information on logistics management training and FP commodities stock keeping. Table 6.1 presents the percentage distribution health facilities with a staff trained in logistics management in the 24 months before the survey, the availability of various FP logistics management forms as well as the data set required.

The results reveal that 60 percent of the health facilities have a staff trained in logistics management in the past 24 months. The percentage of health facilities with a staff trained in logistics management in the past 24 months decreased from 70 percent among health centers/clinics to 38 percent among maternity homes. The proportion of health facilities that have staff trained in logistics management is slightly higher in rural areas (61\%) compared to urban areas (59\%). It was also highest in health facilities in the Central region (75\%) and lowest in the Upper East region (48\%). Health facilities in the non-FP Pilot districts (61\%) are more likely to have staff trained in logistics management in the past 24 months compared to health facilities in the FP Pilot districts (58\%).

On the types of logistics management forms, health facilities use to manage FP commodity stock, more than 9 in 10 (94\%) of the health facilities use stocks/bin cards/inventory cards. More than a third (36\%) use a stock ledger, and 6 percent use other types of forms. At least more than 7 in 10 health facilities across background characteristics use stock cards/bin cards/inventory cards to manage FP commodity stock.

It is important that FP logistics management forms include information on quantities of commodities used, losses, and adjustments. From Table 6.1, more than 9 in 10 (95\%) of health facilities indicated that their commodity management forms include a section on quantities used and more than 8 in 10 (83\%) indicated that their forms include losses and adjustments. 
Table 6. 1 Logistics and stock keeping

Percentage distribution of health facilities with staff trained in logistics management in the past 24 months, percentage distribution of type health facility stock-keeping

forms, and percentage distribution of type of information on facility stock-keeping document by background characteristics, FPNHIS 2021

\begin{tabular}{|c|c|c|c|c|c|c|c|c|c|c|}
\hline & \multirow{2}{*}{$\begin{array}{l}\text { A staff of the } \\
\text { health facility } \\
\text { received } \\
\text { logistics } \\
\text { management } \\
\text { training }\end{array}$} & \multicolumn{3}{|c|}{$\begin{array}{l}\text { Health facility uses the following } \\
\text { to manage FP commodities: }\end{array}$} & \multirow[b]{2}{*}{$\begin{array}{c}\text { Total } \\
\text { number }\end{array}$} & \multicolumn{4}{|c|}{ Health facility stock-keeping logistics forms include: } & \multirow[b]{2}{*}{ Total } \\
\hline & & $\begin{array}{c}\text { Stock cards/bin } \\
\text { card/inventory } \\
\text { card }\end{array}$ & $\begin{array}{l}\text { Stock } \\
\text { ledger }\end{array}$ & $\begin{array}{l}\text { Other } \\
\text { forms }\end{array}$ & & $\begin{array}{l}\text { Stock } \\
\text { on } \\
\text { hand }\end{array}$ & $\begin{array}{c}\text { Quantities } \\
\text { used }\end{array}$ & $\begin{array}{l}\text { Losses and } \\
\text { adjustments }\end{array}$ & $\begin{array}{c}\text { Other } \\
\text { information }\end{array}$ & \\
\hline \multicolumn{11}{|l|}{ Type of Facility } \\
\hline Hospital & 66.3 & 95.2 & 39.8 & 7.2 & 83 & 94.0 & 97.6 & 85.5 & 7.2 & 83 \\
\hline Health Center/Clinic & 69.9 & 94.9 & 39.8 & 5.6 & 216 & 96.8 & 95.4 & 85.2 & 10.6 & 216 \\
\hline $\begin{array}{l}\text { Community-based Health } \\
\text { Planning Services (CHPS) }\end{array}$ & 53.3 & 93.0 & 32.0 & 5.7 & 300 & 92.7 & 95.0 & 82.3 & 5.7 & 300 \\
\hline Maternity Home & 38.1 & 81.0 & 23.8 & 9.5 & 21 & 90.5 & 81.0 & 61.9 & 4.8 & 21 \\
\hline \multicolumn{11}{|l|}{ Location of facility } \\
\hline Rural & 60.8 & 94.9 & 37.6 & 5.3 & 434 & 94.7 & 96.1 & 83.6 & 6.7 & 434 \\
\hline Urban & 59.1 & 90.3 & 30.6 & 7.5 & 186 & 93.0 & 92.5 & 81.7 & 9.7 & 186 \\
\hline \multicolumn{11}{|l|}{ Managing authority } \\
\hline Government & 60.7 & 95.1 & 36.6 & 4.7 & 535 & 95.0 & 96.1 & 85.4 & 7.1 & 535 \\
\hline Private & 56.7 & 85.1 & 23.9 & 13.4 & 67 & 89.6 & 88.1 & 67.2 & 11.9 & 67 \\
\hline Mission/Faith-based & 61.1 & 77.8 & 44.4 & 16.7 & 18 & 88.9 & 88.9 & 72.2 & 5.6 & 18 \\
\hline \multicolumn{11}{|l|}{ Region } \\
\hline Ashanti & 59.4 & 90.6 & 32.2 & 9.4 & 286 & 91.6 & 92.3 & 82.5 & 12.2 & 286 \\
\hline Central & 75.4 & 96.7 & 13.9 & 1.6 & 122 & 98.4 & 97.5 & 91.8 & 1.6 & 122 \\
\hline Oti & 63.4 & 92.7 & 56.1 & 4.9 & 41 & 100.0 & 100.0 & 97.6 & 2.4 & 41 \\
\hline Upper East & 47.6 & 93.9 & 45.1 & 4.9 & 82 & 91.5 & 93.9 & 68.3 & 3.7 & 82 \\
\hline Volta & 52.8 & 98.9 & 57.3 & 2.2 & 89 & 96.6 & 98.9 & 79.8 & 6.7 & 89 \\
\hline \multicolumn{11}{|l|}{ Site } \\
\hline FP Pilot district & 57.6 & 98.3 & 25.4 & 3.4 & 59 & 98.3 & 94.9 & 76.3 & 1.7 & 59 \\
\hline Non-FP Pilot district & 60.6 & 93.0 & 36.5 & 6.2 & 561 & 93.8 & 95.0 & 83.8 & 8.2 & 561 \\
\hline Total & 374 & 580 & 220 & 37 & 620 & 584 & 589 & 515 & 47 & 620 \\
\hline Percent & 60.3 & 93.5 & 35.5 & 6.0 & 100.0 & 94.2 & 95.0 & 83.1 & 7.6 & 100.0 \\
\hline
\end{tabular}

Note: 1 case missing 


\subsection{Reporting Logistics Data to Higher Authorities}

Reporting logistics data in time will enable the higher authority to plan the supply of logistics to health facilities, and this will be critical as the country plans to scale-up the inclusion of FP within the NHI benefits package.

Table 6.2 provides information on how often health facilities send reports containing logistics data to the higher-level authorities. The majority (97\%) of health facilities submit their logistics reports to the higher authorities monthly. This is highest among community-based health planning services (98\%), followed by health centers/clinics (97\%) and lowest among hospitals (95\%) and maternity homes (95\%).

Monthly submission of logistics data to higher authorities is about the same in rural areas (97\%) compared to urban areas (96\%). Reporting logistics data on monthly basis to higher authorities is universal among mission/faith-based health facilities (100\%) and lowest among private health facilities (94\%). More than 9 in 10 health facilities across all the study regions report logistics data to higher authorities monthly and health facilities in the non-FP Pilot sites are more likely to report logistics data monthly compared to health facilities in the FP Pilot districts.

Table 6. 2 Reporting on logistics data to the higher authorities

Percentage of health facilities by how often reports that contain logistics data or records are sent to the higher authorities by background characteristics, FPNHIS 2021

\begin{tabular}{|c|c|c|c|c|c|c|}
\hline & \multicolumn{5}{|c|}{$\begin{array}{c}\text { Reports that contain logistics data or records are sent to the } \\
\text { higher level: }\end{array}$} & \multirow[b]{2}{*}{$\begin{array}{c}\text { Total } \\
\text { number }\end{array}$} \\
\hline & Monthly & Quarterly & $\begin{array}{c}\text { Semi- } \\
\text { annually }\end{array}$ & Annually & $\begin{array}{l}\text { Other } \\
\text { frequency }\end{array}$ & \\
\hline \multicolumn{7}{|l|}{ Type of Facility } \\
\hline Hospital & 95.2 & 3.6 & 0.0 & 0.0 & 1.2 & 83 \\
\hline Health Center/Clinic & 96.8 & 2.3 & 0.5 & 0.5 & 0.0 & 216 \\
\hline $\begin{array}{l}\text { Community-based Health Planning } \\
\text { Services (CHPS) }\end{array}$ & 97.7 & 2.0 & 0.0 & 0.0 & 0.3 & 300 \\
\hline Maternity Home & 95.2 & 0.0 & 0.0 & 4.8 & 0.0 & 21 \\
\hline \multicolumn{7}{|l|}{ Location of facility } \\
\hline Rural & 97.2 & 2.1 & 0.2 & 0.2 & 0.2 & 434 \\
\hline Urban & 96.2 & 2.7 & 0.0 & 0.5 & 0.5 & 186 \\
\hline \multicolumn{7}{|l|}{ Managing authority } \\
\hline Government & 97.2 & 2.4 & 0.0 & 0.2 & 0.2 & 535 \\
\hline Private & 94.0 & 1.5 & 1.5 & 1.5 & 1.5 & 67 \\
\hline Mission/Faith-based & 100.0 & 0.0 & 0.0 & 0.0 & 0.0 & 18 \\
\hline \multicolumn{7}{|l|}{ Region } \\
\hline Ashanti & 97.2 & 1.7 & 0.3 & 0.3 & 0.3 & 286 \\
\hline Central & 98.4 & 1.6 & 0.0 & 0.0 & 0.0 & 122 \\
\hline Oti & 97.6 & 2.4 & 0.0 & 0.0 & 0.0 & 41 \\
\hline Upper East & 93.9 & 3.7 & 0.0 & 1.2 & 1.2 & 82 \\
\hline Volta & 96.6 & 3.4 & 0.0 & 0.0 & 0.0 & 89 \\
\hline \multicolumn{7}{|l|}{ Site } \\
\hline FP Pilot district & 94.9 & 5.1 & 0.0 & 0.0 & 0.0 & 59 \\
\hline Non-FP Pilot district & 97.1 & 2.0 & 0.2 & 0.4 & 0.4 & 561 \\
\hline Total & 601 & 14 & 1 & 2 & 2 & 620 \\
\hline Percent & 96.9 & 2.3 & 0.2 & 0.3 & 0.3 & 100.0 \\
\hline
\end{tabular}

Note: 1 missing case 


\subsection{Supply of Family Planning Commodities}

The provision of FP services depends on the availability of commodities. With the anticipation that the inclusion of FP into the NHIS, uptake of FP services will increase, the FPNHIS collected information on the last time health facilities requested for FP commodities, and the average time it took between ordering and receiving commodities to assess FP commodity supply. Table 6.3 shows the percentage distribution of health facilities by the last time health facilities requested for FP commodities and the duration between ordering and receiving the commodities.

Overall, 44 percent of health facilities requested FP commodities less than one month ago, 41 percent requested 1-2 months ago, and 10 percent requested more than 3 months ago. More than half (56\%) received it in less than a week, and 29 percent of health facilities received the commodities between two weeks to one month.

A higher percentage of maternity homes (86\%) received their FP commodities in less than two weeks compared to hospitals (67\%). A little more than 5 in 10 (53\%) of community-based health planning services received commodities in less than two weeks. A higher percentage (69\%) of health facilities in urban areas received their FP commodities in less than two weeks after ordering compared to health facilities in rural areas (51\%). In terms of health facilities receiving FP commodities requested in less than two weeks, Ashanti region is the highest (77\%) and Volta (29\%) and Oti (29\%) regions are the lowest. 


\section{Table 6. 3 Supply of family planning commodities}

Percentage of health facilities by when they requested for FP commodities, percentage distribution of health facilities by how long it takes between ordering and receiving of FP commodities by background characteristics, FPNHIS 2021

\begin{tabular}{|c|c|c|c|c|c|c|c|c|c|c|c|}
\hline & \multicolumn{5}{|c|}{ Last time health facilities requested for FP commodities: } & \multirow[b]{2}{*}{$\begin{array}{c}\text { Total } \\
\text { number }\end{array}$} & \multicolumn{4}{|c|}{$\begin{array}{l}\text { How long it takes between ordering and } \\
\text { receiving FP commodities: }\end{array}$} & \multirow[b]{2}{*}{$\begin{array}{c}\text { Total } \\
\text { number }\end{array}$} \\
\hline & $\begin{array}{l}\text { Less } \\
\text { than one } \\
\text { month } \\
\text { ago }\end{array}$ & $\begin{array}{c}1-2 \\
\text { months } \\
\text { ago }\end{array}$ & $\begin{array}{l}3 \text { months } \\
\text { ago }\end{array}$ & $\begin{array}{c}\text { More } \\
\text { than } 3 \\
\text { months } \\
\text { ago }\end{array}$ & Never & & $\begin{array}{l}\text { Less } \\
\text { than } 2 \\
\text { weeks }\end{array}$ & $\begin{array}{c}2 \text { weeks } \\
\text { to } 1 \\
\text { month }\end{array}$ & $\begin{array}{c}\text { Between } \\
1 \text { and } 2 \\
\text { months }\end{array}$ & $\begin{array}{c}\text { More } \\
\text { than } 2 \\
\text { months }\end{array}$ & \\
\hline \multicolumn{12}{|l|}{ Type of Facility } \\
\hline Hospital & 59.0 & 32.5 & 6.0 & 1.2 & 1.2 & 83 & 67.1 & 26.8 & 4.9 & 1.2 & 82 \\
\hline Health Center/Clinic & 43.5 & 40.3 & 10.6 & 5.6 & 0.0 & 216 & 54.6 & 28.7 & 9.3 & 7.4 & 216 \\
\hline $\begin{array}{l}\text { Community-based Health Planning } \\
\text { Services (CHPS) }\end{array}$ & 40.3 & 43.7 & 10.3 & 5.7 & 0.0 & 300 & 52.7 & 31.7 & 10.7 & 5.0 & 300 \\
\hline Maternity Home & 47.6 & 33.3 & 9.5 & 9.5 & 0.0 & 21 & 85.7 & 9.5 & 4.8 & 0.0 & 21 \\
\hline \multicolumn{12}{|l|}{ Location of facility } \\
\hline Rural & 40.3 & 42.2 & 11.8 & 5.8 & 0.0 & 434 & 51.2 & 32.7 & 10.4 & 5.8 & 434 \\
\hline Urban & 53.2 & 37.1 & 5.4 & 3.8 & 0.5 & 186 & 68.6 & 21.1 & 6.5 & 3.8 & 185 \\
\hline \multicolumn{12}{|l|}{ Managing authority } \\
\hline Government & 43.2 & 41.9 & 10.3 & 4.7 & 0.0 & 535 & 52.7 & 31.6 & 10.1 & 5.6 & 535 \\
\hline Private & 46.3 & 34.3 & 7.5 & 10.4 & 1.5 & 67 & 80.3 & 12.1 & 4.5 & 3.0 & 66 \\
\hline Mission/Faith-based & 66.7 & 27.8 & 5.6 & 0.0 & 0.0 & 18 & 77.8 & 22.2 & 0.0 & 0.0 & 18 \\
\hline \multicolumn{12}{|l|}{ Region } \\
\hline Ashanti & 50.0 & 39.5 & 5.9 & 4.2 & 0.3 & 286 & 76.8 & 16.8 & 6.0 & 0.4 & 285 \\
\hline Central & 32.8 & 47.5 & 12.3 & 7.4 & 0.0 & 122 & 47.5 & 28.7 & 13.1 & 10.7 & 122 \\
\hline Oti & 56.1 & 26.8 & 17.1 & 0.0 & 0.0 & 41 & 29.3 & 48.8 & 12.2 & 9.8 & 41 \\
\hline Upper East & 51.2 & 36.6 & 6.1 & 6.1 & 0.0 & 82 & 41.5 & 34.1 & 14.6 & 9.8 & 82 \\
\hline Volta & 29.2 & 44.9 & 19.1 & 6.7 & 0.0 & 89 & 29.2 & 56.2 & 7.9 & 6.7 & 89 \\
\hline \multicolumn{12}{|l|}{ Site } \\
\hline FP Pilot district & 45.8 & 39.0 & 8.5 & 6.8 & 0.0 & 59 & 57.6 & 23.7 & 11.9 & 6.8 & 59 \\
\hline Non-FP Pilot district & 44.0 & 40.8 & 10.0 & 5.0 & 0.2 & 561 & 56.3 & 29.8 & 8.9 & 5.0 & 560 \\
\hline Total & 274 & 252 & 61 & 32 & 1 & 620 & 349 & 181 & 57 & 32 & 619 \\
\hline Percent & 44.2 & 40.6 & 9.8 & 5.2 & 0.2 & 100.0 & 56.4 & 29.2 & 9.2 & 5.2 & 100.0 \\
\hline
\end{tabular}




\subsection{Determination of re-supply of family planning commodities}

Table 6.4 shows which authorities determine FP products re-supply quantities and how FP products re-supply quantities are determined by background characteristics. Generally, health facilities determine the re-supply quantities of FP commodities as the majority $(70 \%)$ of health facilities request their re-supply quantities themselves, 11 percent of the health facilities indicated that a higher-level facility determines its re-supply quantities and close to a fifth (19\%) of health facilities indicated that their re-supply quantities are determined by the district health management team.

Comparing the type of facilities, the highest percentage of hospitals $(83 \%)$ reported that the health facility itself determined its FP products re-supply quantities. The highest proportion of health facilities that indicated that the district health management team determined their facility's FP products re-supply quantities are community-based health planning services (22\%). Most facilities in urban areas (80\%), privately managed facilities (82\%), facilities located in the central region $(79 \%)$, and in the non-FP pilot district $(72 \%)$, indicated their facilities determined their FP products re-supply quantities.

The health facilities reported on how their FP products re-supply quantities are determined in their facilities. Close to a third $(60 \%)$ of health facilities mentioned that they use remaining stock to determine their FP products' re-supply quantities, which is the highest followed by 37 percent of health facilities indicating FP products re-supply quantities are determined through calculations using formula. Among the types of health facilities, facility location, managing authorities, region of the facility, and the sites of the study, a higher percentage (more than half) of maternity homes, facilities managed by mission/faith-based institutions, facilities in urban areas, the Ashanti region and non-FP pilot districts reported using remaining stock. 


\section{Table 6. 4 Determination of re-supply of family planning commodities}

Percentage distribution of health facilities by who determines facility FP re-supply quantities, and percent distribution of health facilities by how health facility FP re-supply quantities are determined

\begin{tabular}{|c|c|c|c|c|c|c|c|c|c|c|}
\hline & \multicolumn{4}{|c|}{$\begin{array}{l}\text { The authority that determines this } \\
\text { facility's FP products re-supply quantities: }\end{array}$} & \multirow[b]{2}{*}{$\begin{array}{c}\text { Total } \\
\text { number }\end{array}$} & \multicolumn{4}{|c|}{$\begin{array}{l}\text { Facility's FP products re-supply quantities are } \\
\text { determined through: }\end{array}$} & \multirow[b]{2}{*}{$\begin{array}{l}\text { Total } \\
\text { number }\end{array}$} \\
\hline & $\begin{array}{l}\text { The } \\
\text { facility } \\
\text { itself }\end{array}$ & $\begin{array}{l}\text { Higher- } \\
\text { level } \\
\text { facility }\end{array}$ & $\begin{array}{l}\text { District } \\
\text { Health } \\
\text { Management } \\
\text { Team }\end{array}$ & Other & & $\begin{array}{l}\text { Calculation } \\
\text { using } \\
\text { formula }\end{array}$ & $\begin{array}{l}\text { Remaining } \\
\text { stock }\end{array}$ & $\begin{array}{l}\text { Stipulated } \\
\text { ration }\end{array}$ & Other & \\
\hline \multicolumn{11}{|l|}{ Type of Facility } \\
\hline Hospital & 83.1 & 2.4 & 14.5 & 0.0 & 83 & 32.5 & 66.3 & 0.0 & 1.2 & 83 \\
\hline Health Center/Clinic & 71.3 & 10.6 & 18.1 & 0.0 & 216 & 40.3 & 57.9 & 1.9 & 0.0 & 216 \\
\hline $\begin{array}{l}\text { Community-based Health Planning Services } \\
\text { (CHPS) }\end{array}$ & 64.3 & 14.0 & 21.7 & 0.0 & 300 & 37.3 & 60.7 & 2.0 & 0.0 & 300 \\
\hline Maternity Home & 71.4 & 14.3 & 14.3 & 0.0 & 21 & 14.3 & 85.7 & 0.0 & 0.0 & 21 \\
\hline \multicolumn{11}{|l|}{ Location of facility } \\
\hline Rural & 65.0 & 12.9 & 22.1 & 0.0 & 434 & 38.5 & 59.9 & 1.6 & 0.0 & 434 \\
\hline Urban & 80.1 & 7.5 & 12.4 & 0.0 & 186 & 33.3 & 64.5 & 1.6 & 0.5 & 186 \\
\hline \multicolumn{11}{|l|}{ Managing authority } \\
\hline Government & 68.2 & 12.1 & 19.6 & 0.0 & 535 & 39.8 & 58.5 & 1.7 & 0.0 & 535 \\
\hline Private & 82.1 & 6.0 & 11.9 & 0.0 & 67 & 19.4 & 77.6 & 1.5 & 1.5 & 67 \\
\hline Mission/Faith-based & 61.1 & 5.6 & 33.3 & 0.0 & 18 & 16.7 & 83.3 & 0.0 & 0.0 & 18 \\
\hline \multicolumn{11}{|l|}{ Region } \\
\hline Ashanti & 65.0 & 9.8 & 25.2 & 0.0 & 286 & 23.4 & 75.2 & 1.0 & 0.3 & 286 \\
\hline Central & 78.7 & 5.7 & 15.6 & 0.0 & 122 & 67.2 & 32.0 & 0.8 & 0.0 & 122 \\
\hline Oti & 78.0 & 22.0 & 0.0 & 0.0 & 41 & 46.3 & 53.7 & 0.0 & 0.0 & 41 \\
\hline Upper East & 58.5 & 14.6 & 26.8 & 0.0 & 82 & 42.7 & 56.1 & 1.2 & 0.0 & 82 \\
\hline Volta & 77.5 & 15.7 & 6.7 & 0.0 & 89 & 29.2 & 65.2 & 5.6 & 0.0 & 89 \\
\hline \multicolumn{11}{|l|}{ Site } \\
\hline FP Pilot district & 42.4 & 8.5 & 49.2 & 0.0 & 59 & 47.5 & 52.5 & 0.0 & 0.0 & 59 \\
\hline Non-FP Pilot district & 72.4 & 11.6 & 16.0 & 0.0 & 561 & 35.8 & 62.2 & 1.8 & 0.2 & 561 \\
\hline Total & 431 & 70 & 119 & 0 & 620 & 229 & 380 & 10 & 1 & 620 \\
\hline Percent & 69.5 & 11.3 & 19.2 & 0.0 & 100.0 & 36.9 & 61.3 & 1.6 & 0.2 & 100.0 \\
\hline
\end{tabular}

Note: 1 missing case 


\section{REGISTRY OF FAMILY PLANNING SERVICE DATA}

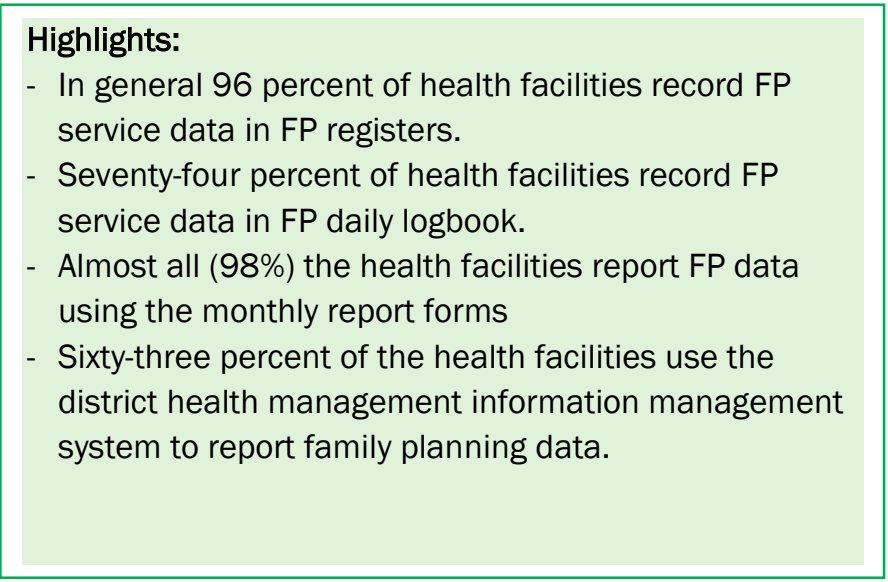

Recording and reporting of FP data are important for the inclusion of FP into the NHIS package. Data on services are critical to claims processing, reimbursement as well as monitoring. Hence, this chapter assesses how FP service data are recorded and reported to higher-level authorities in health facilities.

\subsection{Recording and Reporting of Family Planning Service Data}

Table 7.1 shows the percentage distribution of how FP service data are recorded and reported in health facilities by background characteristics. Overall, more than 9 in 10 of health facilities record FP service data in FP registers (96\%), which is the highest, followed by daily logbooks (74\%), e-tracker (6\%), rslog (2\%), and other recording mediums (1\%). Across background characteristics, more than 9 in 10 health facilities use FP registers, and at least half use FP logbooks.

With respect to reporting FP service data, almost all the health facilities (98\%) use the monthly report forms, two-thirds (63\%) of the health facilities use the District Health Information Management System and less than 1 percent use other methods of reporting FP service data. The majority of health facilities use the monthly report forms (98\%). 
Table 7.1 Recording and reporting of family planning service data

Percentage distribution of health facilities by how FP service data is recorded and percentage distribution of health facilities by how FP service data is reported by background characteristics, FPNHIS 2021

\begin{tabular}{|c|c|c|c|c|c|c|c|c|c|c|}
\hline 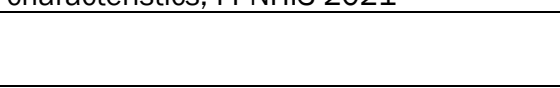 & \multicolumn{5}{|c|}{ How is FP data recorded in this facility: } & \multirow[b]{2}{*}{$\begin{array}{l}\text { Total } \\
\text { Number }\end{array}$} & \multicolumn{3}{|c|}{$\begin{array}{l}\text { How is the FP data reported in this } \\
\text { facility: }\end{array}$} & \multirow[b]{2}{*}{$\begin{array}{l}\text { Total } \\
\text { Number }\end{array}$} \\
\hline & $\begin{array}{l}\text { FP } \\
\text { register }\end{array}$ & $\begin{array}{l}\text { FP daily } \\
\text { logbook }\end{array}$ & $\begin{array}{l}\text { e- } \\
\text { Tracker }\end{array}$ & rsLog & Other & & $\begin{array}{l}\text { Monthly } \\
\text { report } \\
\text { forms }\end{array}$ & DHIMS & Other & \\
\hline \multicolumn{11}{|l|}{ Type of Facility } \\
\hline Hospital & 96.4 & 84.3 & 7.2 & 4.8 & 2.4 & 83 & 95.2 & 74.7 & 1.2 & 83 \\
\hline Health Center/Clinic & 95.4 & 78.2 & 6.5 & 0.9 & 1.4 & 216 & 97.7 & 64.4 & 0.0 & 216 \\
\hline $\begin{array}{l}\text { Community-based Health Planning } \\
\text { Services (CHPS) }\end{array}$ & 96.0 & 68.7 & 5.7 & 1.0 & 1.0 & 300 & 98.3 & 59.3 & 0.3 & 300 \\
\hline Maternity Home & 100.0 & 52.4 & 0.0 & 0.0 & 0.0 & 21 & 100.0 & 47.6 & 0.0 & 21 \\
\hline \multicolumn{11}{|l|}{ Location of facility } \\
\hline Rural & 97.0 & 72.6 & 4.8 & 0.7 & 0.5 & 434 & 97.9 & 59.2 & 0.2 & 434 \\
\hline Urban & 93.5 & 75.8 & 8.6 & 3.2 & 3.2 & 186 & 97.3 & 71.0 & 0.5 & 186 \\
\hline \multicolumn{11}{|l|}{ Managing authority } \\
\hline Government & 97.0 & 75.0 & 6.2 & 1.3 & 0.9 & 535 & 98.5 & 62.4 & 0.2 & 535 \\
\hline Private & 88.1 & 59.7 & 4.5 & 1.5 & 4.5 & 67 & 91.0 & 62.7 & 1.5 & 67 \\
\hline Mission/Faith-based & 94.4 & 83.3 & 5.6 & 5.6 & 0.0 & 18 & 100.0 & 72.2 & 0.0 & 18 \\
\hline \multicolumn{11}{|l|}{ Region } \\
\hline Ashanti & 94.1 & 77.6 & 1.7 & 1.0 & 2.1 & 286 & 96.5 & 58.0 & 0.3 & 286 \\
\hline Central & 97.5 & 81.1 & 4.1 & 0.0 & 0.8 & 122 & 99.2 & 84.4 & 0.8 & 122 \\
\hline Oti & 100.0 & 68.3 & 0.0 & 0.0 & 0.0 & 41 & 100.0 & 65.9 & 0.0 & 41 \\
\hline Upper East & 93.9 & 50.0 & 18.3 & 7.3 & 1.2 & 82 & 96.3 & 69.5 & 0.0 & 82 \\
\hline Volta & 100.0 & 74.2 & 13.5 & 0.0 & 0.0 & 89 & 100.0 & 40.4 & 0.0 & 89 \\
\hline \multicolumn{11}{|l|}{ Site } \\
\hline FP Pilot district & 93.2 & 74.6 & 18.6 & 6.8 & 0.0 & 59 & 100.0 & 69.5 & 0.0 & 59 \\
\hline Non-FP Pilot district & 96.3 & 73.4 & 4.6 & 0.9 & 1.4 & 561 & 97.5 & 62.0 & 0.4 & 561 \\
\hline Total & 595 & 456 & 37 & 9 & 8 & 620 & 606 & 389 & 2 & 620 \\
\hline Percent & 96.0 & 73.5 & 6.0 & 1.5 & 1.3 & 100.0 & 97.7 & 62.7 & 0.3 & 100.0 \\
\hline
\end{tabular}

Note: 1 missing case 


\section{CONCLUSIONS AND RECOMMENDATIONS}

\subsection{Conclusion}

In the five study regions (Ashanti, Central, Oti, Upper East, and Volta), FP services are available and health facilities are ready for the scale-up of the inclusion of FP into the NHIS package. Facilities assessed were found to have the ability and capacity to offer FP services. Most facilities have trained staff, equipment, and supplies including medicines and commodities. Health facilities are also willing to provide FP services under the NHIS package, with mechanisms for supply chain and logistics as well as the recording and reporting of FP service data generally in place.

\subsection{Recommendations}

Based on the findings the following recommendations are suggested:

- The inclusion of FP into the national health insurance scheme can be scaled up in all the districts in the five study regions as FP services are available and health facilities are ready.

- The Ghana Health Service should work toward improving commodity distribution.

- The National Health Insurance Authority should work with Ghana Health Service to credential providers who are interested in providing services under the scheme as well as address delays in credentialing.

- The National Health Insurance Authority and Ghana Health Service should work together to reach out to the FP Pilot districts to address challenges with the provision of FP within the National Health Insurance Scheme package. 


\section{APPENDIX 1: PERSONS INVOLVED IN THE HEALTH FACILITY ASSESSMENT SURVEY}

\author{
Prof. Augustine Ankomah \\ Dr. Kamil Fuseini \\ Dr. Kofi Issah \\ Dr. Yaa Asante \\ Claudette Ahliba Diogo \\ Angela Boateng \\ Henry Safori \\ Rebecca Tricia Morrison \\ Dr. Wisdom Atiwoto \\ Dr. Ernest Konadu Aseidu \\ Rahilu Harunah \\ Selina Dussey \\ Dr. Francis Asenso Boadi \\ Ishmail Osei \\ Ruby A. Mensah \\ William Omane-Adjekum \\ Lydia Anaab-Bisi \\ Habakkuk Tarezina \\ Victoria Adubia Twum \\ Anne Coolen \\ Patricia Antwi-Boasiako \\ Esi Asare Prah
}

Prof. Augustine Ankomah

Dr. Kamil Fuseini

Akua Danquah Obeng-Dwamena Leonie Afi Allorsey

Rachel Narki Anum

Dr. Kofi Issah

Dr. Yaa Asante

Claudette Ahliba Diogo

Henry Safori

Prof. Augustine Ankomah

Dr. Kamil Fuseini

Akua Danquah Obeng-Dwamena

Leonie Afi Allorsey

Rachel Narki Anum

Prof. Augustine Ankomah

Dr. Kamil Fuseini

Akua Danquah Obeng-Dwamena

Leonie Afi Allorsey

Rachel Narki Anum

Bright Addo

Helen Habib

Stephen Semenu

\section{TECHNICAL WORKING GROUP}

Population Council

Population Council

Ghana Health Service, Family Health Division

Ghana Health Service, Family Health Division

Ghana Health Service, Family Health Division

Ghana Health Service, Family Health Division

Ghana Health Service, Family Health Division

Ghana Health Service, Family Health Division

Ghana Health Service, PPMED

Ministry of Health

Ministry of Health

Ministry of Health

National Health Insurance Authority

National Health Insurance Authority

National Health Insurance Authority

National Health Insurance Authority

National Health Insurance Authority

National Health Insurance Authority

National Health Insurance Authority

Marie Stopes International, Ghana

Marie Stopes International, Ghana

Marie Stopes International, Ghana

\section{STUDY IMPLEMENTATION TEAM}

Population Council

Population Council

Population Council

Population Council

Population Council

Ghana Health Service, Family Health Division

Ghana Health Service, Family Health Division

Ghana Health Service, Family Health Division

Ghana Health Service, Family Health Division

\section{DATA ANALYSIS}

Population Council

Population Council

Population Council

Population Council

Population Council

\section{REPORT WRITING}

Population Council

Population Council

Population Council

Population Council

Population Council

Population Council

Population Council

\section{IT SUPPORT}

Population Council 
Sedzro Kojo Mensah

Sedzro Kojo Mensah Charles Mensah

Bridget Oduro

Djomoah Cartwright Adjabeng

Enoch Adjei Boadi

Henry Prosper Dade

Galley Raymond Prince

Raphael Berkoh

Ebenezer Hanson

Ayiwole Babugu Godfred

Braimah Muniru

Joyce Kporvi

William Awutey

Nicholas Tetteh

Emmanuel Arthur
PROGRAMING AND DATA MANAGEMENT

DataPlas / Population Council

\section{SUPERVISION AND DATA PROCESSING}

DataPlas / Population Council

Population Council

\section{DATA COLLECTORS}

Charles Afriyie Agyapong

Emmanuel Ofori

Ernestina Osei Bonsu

Lydia Sampana

Philip Jeffery Tetteh

Gifty Hinson

Christmond Dadzie

Ayiwole Babugu Raphael

Banzie Joachim

Irene Safoa

Xenyo Dickson

\section{DRIVER}

Population Council
Cara Aidoo

Ebenezer Attoh

Francisca Atta Boateng

Millicent Tetteh

Rachael Asare

Alice Ohenewa Larbi

Mavis Inkoom

Braimah Sule

Limann Moses

Elizabeth Anim Appiah

Dzakumah Ernest Kwame 


\section{APPENDIX 2: SAMPLE SIZE CALCULATION}

The sample size was calculated as follows:

$$
n=\frac{\frac{z^{2} P(1-P)}{d^{2}}}{1+\frac{1}{N}\left(\frac{z^{2} P(1-P)}{d^{2}}-1\right)}
$$

With:

$\begin{array}{ll}\text { Confidence Level= } & 95 \% \\ \text { Z-score }= & 1.96 \\ \text { Precision }+/-= & 5 \% \\ \text { Population Size }= & 3616 \\ \text { Assumed } \mathrm{P}= & 50 \% \\ \text { Sample size }(n)= & 348 \text { facilities }\end{array}$

Note: the population size was the total number of health facilities in the five FP Pilot regions which were 3616 and It was assumed that 50\% (conservative) of health facilities in the study area will be credentialled by NHIA.

i. The sample size of 348 was adjusted for design effect of 1.5 plus $10 \%$ of the sample to account for dropout (e.g., facilities that are no longer operational), resulting in a sample of 580. After the distribution of the sample per district, the sample was further adjusted to 623 health facilities.

ii. The sample of 623 health facilities was distributed proportionately to the number of health facilities per region.

iii. The number of health facilities assigned to a region was then distributed proportionately to the number of health facilities in each district in the region.

iv. Then the number of health facilities assigned to a district was further divided proportionately to the distribution of hospitals, health centers/clinics, and CHPS.

v. Facilities within each category in each district will be selected randomly across rural and urban areas (where feasible).

Total number of facilities and sample of facilities for each region

\begin{tabular}{|l|r|r|r|r|r|r|r|r|r|}
\hline & \multicolumn{4}{|c|}{ Number of facilities } & \multicolumn{4}{|c|}{ Sample } \\
\hline Region & $\begin{array}{r}\text { Number } \\
\text { of } \\
\text { Districts }\end{array}$ & CHPS & $\begin{array}{r}\text { Health } \\
\text { center/Clinic }\end{array}$ & Hospitals & Total & CHPS & $\begin{array}{r}\text { Health } \\
\text { center/Clinic }\end{array}$ & Hospitals & Total \\
\hline Ashanti & 43 & 1111 & 397 & 182 & 1690 & 177 & 68 & 43 & 288 \\
\hline Central & 22 & 446 & 210 & 32 & 688 & 71 & 35 & 16 & 122 \\
\hline Upper East & 15 & 363 & 112 & 16 & 491 & 57 & 18 & 8 & 83 \\
\hline Volta & 18 & 318 & 169 & 31 & 518 & 50 & 27 & 12 & 89 \\
\hline Oti & 8 & 173 & 49 & 7 & 229 & 28 & 8 & 5 & 41 \\
\hline TOTAL & 106 & 2411 & 937 & 268 & 3616 & 383 & 156 & 84 & 623 \\
\hline
\end{tabular}




\section{APPENDIX 3: QUESTIONNAIRE}

Health Facility Assessment Questionnaire

Evaluating the Inclusion of Family Planning Within the National Health Insurance (NHI) Benefits Package in Ghana

Instructions for researcher: Address this questionnaire to the In-Charge of the health facility, or a designated individual who is knowledgeable about the health facility and family planning services in the health facility. Let the in-charge or facility designee know you will ask general questions about the facility and the availability of family planning services at the facility. The form can be completed over more than one visit or call and by consulting more than one staff member from the facility.

Setting where the instrument will be used: This instrument will be used in selected health facilities in all the FP Pilot regions.

Obtain oral permission from the In-Charge or facility designee prior to conducting this questionnaire.

Note: All instructions for Research Assistants are written in bold and italicized. 


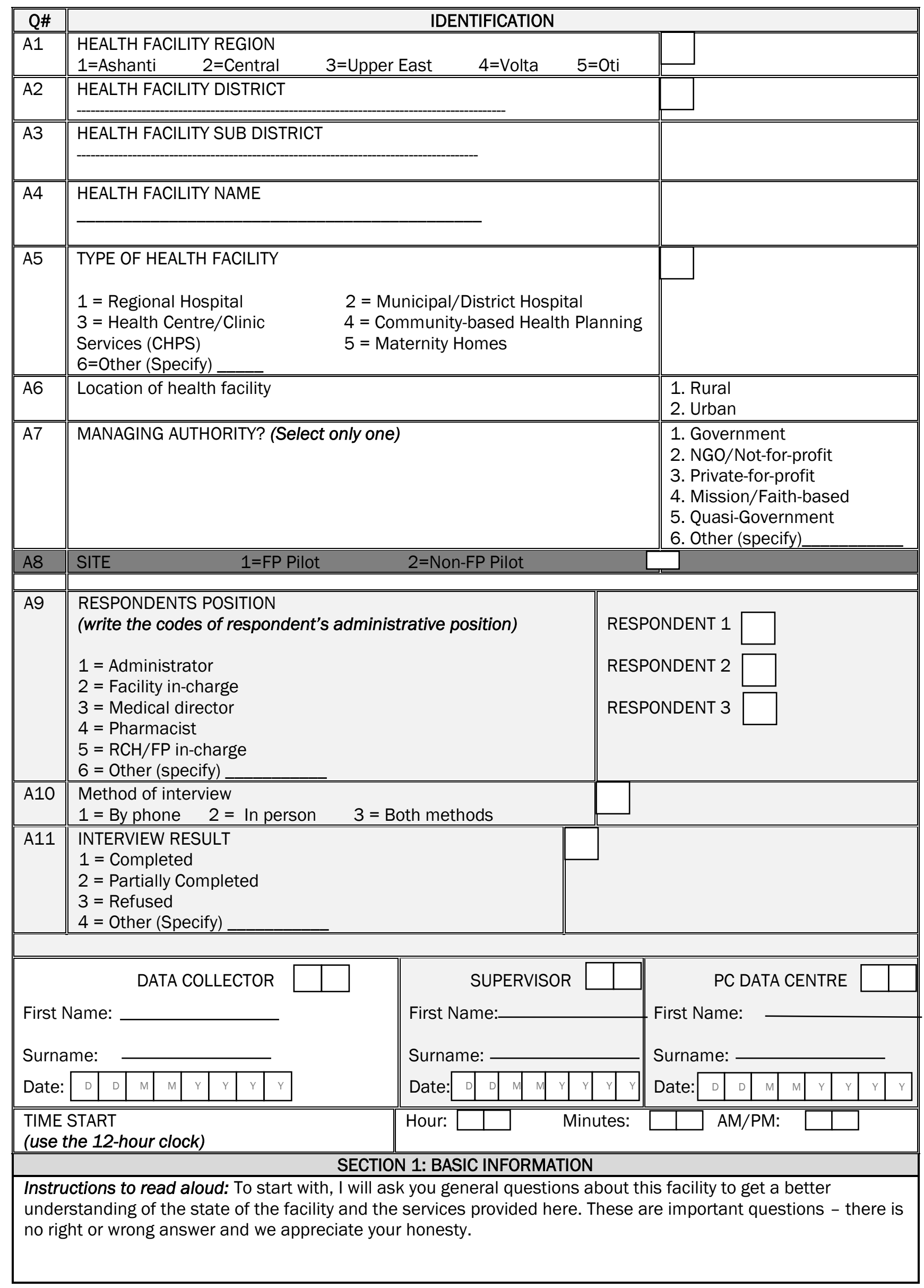




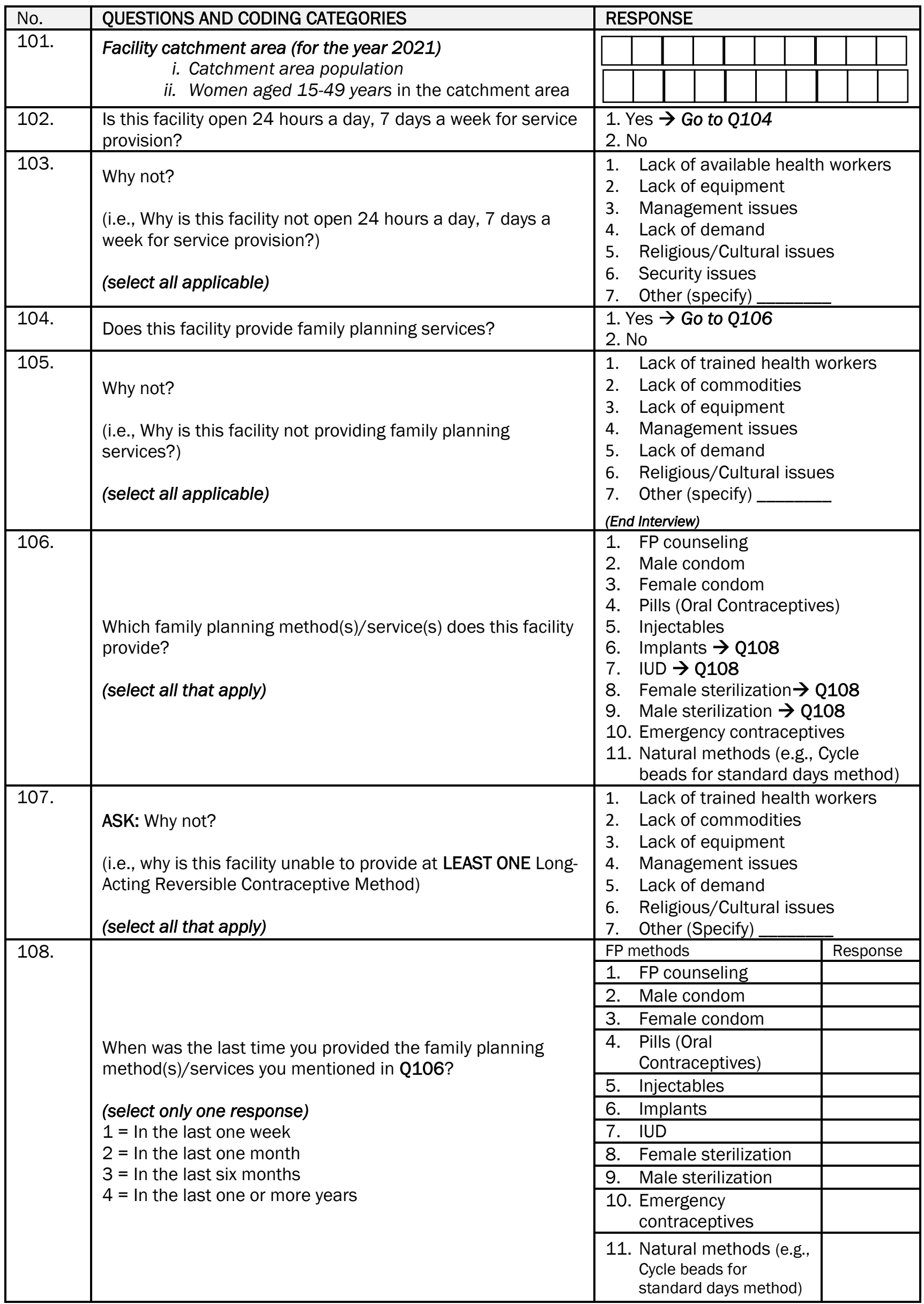




\begin{tabular}{|c|c|c|}
\hline No. & QUESTIONS AND CODING CATEGORIES & RESPONSE \\
\hline 109. & $\begin{array}{l}\text { Does this facility offer adolescent-friendly family planning } \\
\text { services? }\end{array}$ & $\begin{array}{l}\text { 1. Yes } \rightarrow \text { Go to Q111 } \\
\text { 2. No }\end{array}$ \\
\hline 110. & $\begin{array}{l}\text { Why not? } \\
\text { (i.e., Why is this facility NOT providing adolescent-friendly } \\
\text { family planning services?) } \\
\text { (select all applicable) }\end{array}$ & $\begin{array}{l}\text { 1. Lack of trained health workers } \\
\text { 2. Lack of commodities } \\
\text { 3. Lack of equipment } \\
\text { 4. Management issues } \\
\text { 5. Lack of demand } \\
\text { 6. Religious/Cultural issues } \\
\text { 7. Other (specify) }\end{array}$ \\
\hline 111. & $\begin{array}{l}\text { Does this facility provide GENERAL health services under the } \\
\text { National Health Insurance Scheme (NHIS) package? }\end{array}$ & $\begin{array}{l}\text { 1. Yes } \rightarrow \text { Go to } Q 113 \\
\text { 2. No }\end{array}$ \\
\hline 112. & $\begin{array}{l}\text { Why not? } \\
\text { (i.e., why is this facility unable to provide health services } \\
\text { under the National Health Insurance Scheme (NHIS) } \\
\text { package) } \\
\text { (select all that apply) }\end{array}$ & $\begin{array}{ll}\text { 1. } & \text { Facility is not credentialled } \\
\text { 2. } & \text { Inactive credentialling } \\
\text { 3. } & \text { Lack of training in NHIA SOPs } \\
\text { 4. } & \text { Lack of equipment } \\
\text { 5. } & \text { Management issues } \\
\text { 6. } & \text { Legal issues } \\
\text { 7. } & \text { Delays in provider reimbursement } \\
\text { 8. } & \text { Facility not interested } \\
\text { 9. } & \text { Other (Specify) } \\
\end{array}$ \\
\hline 113. & $\begin{array}{l}\text { Has any health provider in this facility received training on } \\
\text { submitting National Health Insurance Scheme (NHIS) } \\
\text { claims? }\end{array}$ & $\begin{array}{l}\text { 1. Yes } \rightarrow \text { Go to } Q 115 \\
\text { 2. No }\end{array}$ \\
\hline 114. & $\begin{array}{l}\text { Why not? } \\
\text { (i.e., why has no health provider in this facility been trained in } \\
\text { submitting National Health Insurance Scheme (NHIS) } \\
\text { claims?) } \\
\text { (select all that apply) }\end{array}$ & $\begin{array}{ll}\text { 1. } & \text { Facility is not credentialled } \\
\text { 2. } & \text { Inactive credentialling } \\
\text { 3. } & \text { Lack of training in NHIA SOPS } \\
\text { 4. Lack of equipment } \\
\text { 5. Management issues } \\
\text { 6. Legal issues } \\
\text { 7. Delays in provider reimbursement } \\
\text { 8. Facility not interested } \\
\text { 9. } \\
\end{array}$ \\
\hline 115. & $\begin{array}{l}\text { If YES to Q111, ASK } \\
\text { Does this facility provide family planning services under the } \\
\text { National Health Insurance Scheme (NHIS) package? }\end{array}$ & $\begin{array}{l}\text { 1. Yes } \\
\text { 2. No } \rightarrow \text { Go to } Q 117\end{array}$ \\
\hline 116. & $\begin{array}{l}\text { Which family planning method(s)/Service(s) does this facility } \\
\text { provide under the National Health Insurance Scheme (NHIS) } \\
\text { package? } \\
\text { (select all that apply) }\end{array}$ & $\begin{array}{l}\text { 1. FP Counseling } \\
\text { 2. Male condom } \\
\text { 3. Female condom } \\
\text { 4. Pills (Oral Contraceptives) } \\
\text { 5. Injectables } \\
\text { 6. Implants } \\
\text { 7. IUD } \\
\text { 8. Female sterilization } \\
\text { 9. Male sterilization } \\
\text { 10. Emergency contraceptives } \\
\text { 11. Natural methods (e.g. Cycle beads } \\
\rightarrow \text { for standard days method) } \\
\rightarrow \text { Go to Q120 }\end{array}$ \\
\hline 117. & $\begin{array}{l}\text { Why not? } \\
\text { (i.e., why is this facility unable to provide family planning } \\
\text { services under the National Health Insurance Scheme (NHIS) } \\
\text { package) } \\
\text { (select all that apply) }\end{array}$ & $\begin{array}{l}\text { 1. Facility is not credentialled } \\
\text { 2. Inactive credentialling } \\
\text { 3. Lack of equipment } \\
\text { 4. Management issues } \\
\text { 5. Legal issues } \\
\text { 6. FP not included in NHIS package } \\
\text { 7. Delays in provider reimbursement } \\
\text { 8. Facility not interested } \\
\text { 9. Other (Specify) }\end{array}$ \\
\hline
\end{tabular}




\begin{tabular}{|c|c|c|c|}
\hline No. & QUESTIONS AND CODING CATEGORIES & \multicolumn{2}{|l|}{ RESPONSE } \\
\hline 118. & $\begin{array}{l}\text { Is this facility willing to provide family planning services } \\
\text { under the National Health Insurance Scheme (NHIS) } \\
\text { package? }\end{array}$ & \multicolumn{2}{|c|}{$\begin{array}{l}\text { 1. Yes } \rightarrow \text { Go to } Q 120 \\
\text { 2. No }\end{array}$} \\
\hline 119. & $\begin{array}{l}\text { Why not? } \\
\text { (i.e., why is this facility not willing to provide family planning } \\
\text { services under the National Health Insurance Scheme (NHIS) } \\
\text { package) } \\
\text { (select all that apply) }\end{array}$ & \multicolumn{2}{|c|}{$\begin{array}{l}\text { 1. Facility is not credentialled } \\
\text { 2. Inactive credentialling } \\
\text { 3. Lack of trained health workers } \\
\text { 4. Lack of equipment } \\
\text { 5. Management issues } \\
\text { 6. Legal issues } \\
\text { 7. FP not included in NHIS benefit } \\
\text { 8. Dackage } \\
\text { 9. Facility not interested } \\
\text { 10. } \\
\end{array}$} \\
\hline 120. & $\begin{array}{l}\text { On average, how many days each week are family planning } \\
\text { services provided at this facility? }\end{array}$ & \multicolumn{2}{|c|}{$\begin{array}{ll}\text { 1. } & 1 \\
\text { 2. } & 2 \\
\text { 3. } & 3 \\
\text { 4. } & 4 \\
\text { 5. } & 5 \rightarrow \text { Go to } Q 122 \\
\text { 6. } & 6 \rightarrow \text { Go to } Q 122 \\
\text { 7. } & 7 \rightarrow \text { Go to } Q 122 \\
\end{array}$} \\
\hline 121. & $\begin{array}{l}\text { Why not? } \\
\text { (i.e., why is this facility not able to provide family planning } \\
\text { services at least } 5 \text { days a week?) } \\
\text { (select all applicable) }\end{array}$ & $\begin{array}{l}\text { 1. Lack of } t \\
\text { 2. Lack of } \\
\text { 3. Lack of } \\
\text { 4. Manage } \\
\text { 5. Lack of } \\
\text { 6. Religiou } \\
\text { 7. Other (S }\end{array}$ & $\begin{array}{l}\text { ned health workers } \\
\text { nmodities } \\
\text { ipment } \\
\text { nt issues } \\
\text { nand } \\
\text { ultural issues } \\
\text { ify) }\end{array}$ \\
\hline 122. & \multicolumn{3}{|c|}{ On average, how many hours per day are family planning services provided? } \\
\hline 123. & $\begin{array}{l}\text { Does this facility provide contraceptives after post-abortion } \\
\text { care (PAC)? }\end{array}$ & \multicolumn{2}{|c|}{$\begin{array}{l}\text { 1. Yes } \rightarrow \text { Go to Section } 2 \\
\text { 2. No }\end{array}$} \\
\hline 124. & $\begin{array}{l}\text { Why not? } \\
\text { (i.e., Why is this facility not able to provide contraceptives } \\
\text { after Post Abortion Care (PAC)?) } \\
\text { (select all that apply) }\end{array}$ & $\begin{array}{l}\text { 1. Lack of } \\
\text { 2. Lack of } \\
\text { 3. Lack of } \\
\text { 4. Manage } \\
\text { 5. Religious } \\
\text { 6. Legal iss } \\
\text { 7. Other (S }\end{array}$ & $\begin{array}{l}\text { ned health workers } \\
\text { nmodities } \\
\text { ipment } \\
\text { nt issues } \\
\text { ultural issues } \\
\text { s } \\
\text { ify) }\end{array}$ \\
\hline \multicolumn{4}{|c|}{ SECTION 2: AVAILABILITY OF FAMILY PLANNING SERVICES } \\
\hline \multicolumn{4}{|c|}{$\begin{array}{l}\text { Instructions to read aloud: Now I am going to ask some questions about this facility's family planning resources. } \\
\text { For some questions, I may request for evidence or to be taken to a specific area of the facility so that I can } \\
\text { observe it myself. }\end{array}$} \\
\hline 201. & $\begin{array}{l}\text { Is there a designated area/section of the facility where family } \\
\text { planning services are provided including counseling? }\end{array}$ & $\begin{array}{ll}\text { 1. } & \text { Yes } \\
\text { 2. } & \text { No } \\
\end{array}$ & \\
\hline 202. & $\begin{array}{l}\text { Is there a waiting area for family planning clients, where they } \\
\text { are protected from sun and rain? }\end{array}$ & $\begin{array}{ll}\text { 1. Yes } \\
\text { 2. No }\end{array}$ & \\
\hline 203. & $\begin{array}{l}\text { Are there seats for family planning clients in the waiting } \\
\text { area? }\end{array}$ & $\begin{array}{l}\text { 1. Yes } \\
\text { 2. No }\end{array}$ & \\
\hline 204. & $\begin{array}{l}\text { Does the facility have a designated room for family planning } \\
\text { service provision? }\end{array}$ & $\begin{array}{ll}\text { 1. } & \text { Yes } \rightarrow G \\
\text { 2. } & \text { No }\end{array}$ & Q206 \\
\hline 205. & $\begin{array}{l}\text { If no, where are family planning services provided in this } \\
\text { facility? }\end{array}$ & $\begin{array}{l}\text { 1. Shared } r \\
\text { 2. Other }(S\end{array}$ & \\
\hline 206. & Is privacy and confidentiality ensured in the room? & $\begin{array}{l}\text { 1. Yes } \\
\text { 2. No }\end{array}$ & \\
\hline 207. & $\begin{array}{l}\text { Is there a couch/bed for examination in the room for family } \\
\text { planning service provision? }\end{array}$ & $\begin{array}{l}\text { 1. Yes } \\
\text { 2. No }\end{array}$ & \\
\hline
\end{tabular}




\begin{tabular}{|c|c|c|}
\hline No. & QUESTIONS AND CODING CATEGORIES & RESPONSE \\
\hline 208. & $\begin{array}{l}\text { Is there a toilet (latrine) in functional condition which is } \\
\text { available for family planning clients' use? }\end{array}$ & $\begin{array}{ll}\text { 1. } & \text { Yes } \\
\text { 2. } & \text { No }\end{array}$ \\
\hline 209. & $\begin{array}{l}\text { Is there a sign at the entrance of the facility or on the exterior } \\
\text { of the building indicating family planning services are } \\
\text { available? }\end{array}$ & $\begin{array}{l}\text { 1. Yes } \\
\text { 2. No }\end{array}$ \\
\hline 210. & $\begin{array}{l}\text { Observe or get evidence \& record whether any of the } \\
\text { following are available in the room where family planning } \\
\text { services are provided. } \\
\text { (select all applicable) }\end{array}$ & $\begin{array}{l}\text { 1. Samples of various FP methods } \\
\text { (e.g., condoms, injectable, pills) } \\
\text { 2. Penis model } \\
\text { 3. IUD model } \\
\text { 4. Posters for general promotion of } \\
\text { FP } \\
\text { 5. Counseling flip charts } \\
\text { 6. Pregnancy checklist } \\
\text { 7. WHO Medical Eligibility Criteria } \\
\text { 8. } \text { (MEC) Wheel } \\
\text { 9. Other (specify) }\end{array}$ \\
\hline 211. & $\begin{array}{l}\text { What method of counseling do you use for your clients? } \\
\text { (select all applicable) }\end{array}$ & $\begin{array}{l}\text { 1. Group counseling } \\
\text { 2. Individual counseling } \\
\text { 3. Other (specify): }\end{array}$ \\
\hline 212. & $\begin{array}{l}\text { What materials do you use to counsel clients about the use } \\
\text { of contraceptive methods? } \\
\text { (select all applicable) }\end{array}$ & $\begin{array}{ll}\text { 1. } & \text { Visual aids (i.e., flip charts and } \\
\text { posters) } \\
\text { 2. Models } \\
\text { 3. Samples of commodities } \\
\text { 4. No materials available } \\
\text { 5. Other (specify material): }\end{array}$ \\
\hline 213. & $\begin{array}{l}\text { Are there printed materials about family planning (booklets, } \\
\text { fliers, and leaflets) available for clients to take home? } \\
\text { (Ask to see the printed materials) }\end{array}$ & $\begin{array}{ll}\text { 1. } & \text { Yes, verified } \\
\text { 2. } & \text { Yes, not verified } \\
\text { 3. } & \text { Not seen }\end{array}$ \\
\hline 214. & $\begin{array}{l}\text { How are patients scheduled for family planning services? } \\
\text { (select all that are applicable) }\end{array}$ & $\begin{array}{ll}\text { 1. } & \text { Walk in } \\
\text { 2. } & \text { Appointment } \\
\text { 3. } & \text { Referral } \\
\text { 4. } & \text { Other (specify): }\end{array}$ \\
\hline 215. & $\begin{array}{l}\text { How long on the average is the wait time for a client to be } \\
\text { seen by a family planning provider? } \\
\text { Note: "Wait time" is the total time client arrives until } \\
\text { consultation with a provider. }\end{array}$ & Minutes \\
\hline 216. & $\begin{array}{l}\text { Is the facility able to provide services to ALL family planning } \\
\text { clients each day? } \\
\text { (i.e., does staff supply meet client demand?) }\end{array}$ & $\begin{array}{l}\text { 1. Yes } \rightarrow \text { Go to } 219 \\
\text { 2. No }\end{array}$ \\
\hline 217. & $\begin{array}{l}\text { How do you ensure your clients are provided with family } \\
\text { planning services? }\end{array}$ & $\begin{array}{l}\text { 1. } \text { Booked for next/another day } \\
\text { 2. Referred to other facilities } \\
\text { 3. Other (specify): } \\
\end{array}$ \\
\hline 218. & $\begin{array}{l}\text { Why not? } \\
\text { (i.e., Why is this facility NOT able to provide services to ALL } \\
\text { family planning clients each day) } \\
\text { (select all that apply) }\end{array}$ & $\begin{array}{l}\text { 1. Lack of trained health workers } \\
\text { 2. Lack of commodities } \\
\text { 3. Lack of equipment } \\
\text { 4. Management issues } \\
\text { 5. Religious/Cultural issues } \\
\text { 6. Legal issues } \\
\text { 7. Other (Specify) } \\
\end{array}$ \\
\hline 219. & $\begin{array}{l}\text { Ask, if there is an increase in demand for family planning } \\
\text { services, does the facility have enough capacity to provide } \\
\text { family planning services? }\end{array}$ & $\begin{array}{l}\text { 1. Yes } \rightarrow \text { Go to } Q 221 \\
\text { 2. No }\end{array}$ \\
\hline
\end{tabular}




\begin{tabular}{|c|c|c|}
\hline No. & QUESTIONS AND CODING CATEGORIES & RESPONSE \\
\hline 220. & $\begin{array}{l}\text { Why not? } \\
\text { (i.e., Why is this facility unable to provide family planning } \\
\text { services if there is an increase in demand) } \\
\text { (select all that apply) }\end{array}$ & $\begin{array}{l}\text { 1. Lack of trained health workers } \\
\text { 2. Lack of space/limited rooms } \\
\text { available } \\
\text { 3. Lack of commodities } \\
\text { 4. Lack of equipment } \\
\text { 5. Management issues } \\
\text { 6. Other (Specify) }\end{array}$ \\
\hline 221. & $\begin{array}{l}\text { What tests are routinely conducted on women when they } \\
\text { come for family planning services? } \\
\text { (select all that are applicable) }\end{array}$ & $\begin{array}{l}\text { 1. HIV test } \\
\text { 2. Urine test } \\
\text { 3. Pap smear } \\
\text { 4. Pregnancy test } \\
\text { 5. Other(specify test) } \\
\end{array}$ \\
\hline 222. & $\begin{array}{l}\text { IF HIV testing is conducted on FP clients, what services are } \\
\text { provided to the client if the client tests positive? } \\
\text { (select all that are applicable) }\end{array}$ & $\begin{array}{l}\text { 1. Linked to ART clinic } \\
\text { 2. Referred to the laboratory for CD4 } \\
\text { testing } \\
\text { 3. Other, specify service: }\end{array}$ \\
\hline 223. & Is there a link between an HIV/ART clinic and the FP clinic? & $\begin{array}{ll}\text { 1. } & \text { Yes } \\
\text { 2. } & \text { No } \rightarrow \text { Go to Section } 3\end{array}$ \\
\hline 224. & If yes, what is the link? & $\begin{array}{l}\text { 1. Referrals between HIV clinic and } \\
\text { FP clinic } \\
\text { 2. Referrals between FP clinic and } \\
\text { HIV clinic } \\
\text { 3. Other (specify link) }\end{array}$ \\
\hline \multicolumn{3}{|c|}{ SECTION 3: AVAILABILITY OF FP COMMODITIES } \\
\hline \multicolumn{3}{|c|}{$\begin{array}{l}\text { Instructions to read aloud: Now I am going to read a list of contraceptives to get a better understanding of which } \\
\text { contraceptives are available at this facility and how many were dispensed or performed in the past month. For the } \\
\text { following contraceptives listed, could you please respond by saying whether the contraceptive is usually "always } \\
\text { available", "sometimes available", "rarely available" or "never available" when a client requests for them at this } \\
\text { facility. }\end{array}$} \\
\hline 301. & Male condoms & $\begin{array}{ll}\text { 1. } & \text { Always available } \rightarrow \text { Go to Q304 } \\
\text { 2. } & \text { Sometimes available } \rightarrow \text { Go to } \\
\text { Q304 } \\
\text { 3. } \\
\text { 4. } \\
\text { 4. }\end{array}$ \\
\hline 302. & $\begin{array}{l}\text { If "rare" availability for male condoms above, what } \\
\text { reason(s)? } \\
\text { (select all applicable) }\end{array}$ & $\begin{array}{l}\text { 1. Inadequate quantity } \\
\text { 2. Providers not trained to } \\
\text { administer } \\
\text { 3. Inadequate equipment/tools to } \\
\text { provide services } \\
\text { 4. Other (specify reason) } \\
\rightarrow \text { Go to Q304 }\end{array}$ \\
\hline 303. & $\begin{array}{l}\text { If “never available" for male condoms, what reason(s)? } \\
\text { (select all applicable) }\end{array}$ & $\begin{array}{l}\text { 1. Inadequate quantity } \\
\text { 2. Providers not trained to } \\
\text { administer } \\
\text { 3. Inadequate equipment/tools to } \\
\text { provide services } \\
\text { 4. Other (specify reason) }\end{array}$ \\
\hline 304. & Female condoms & $\begin{array}{l}\text { 1. Always available } \rightarrow \text { Go to } Q 307 \\
\text { 2. Sometimes available } \rightarrow \text { Go to } \\
\text { Q307 } \\
\text { 3. Rarely available } \\
\text { 4. Never available } \rightarrow \text { Go to Q306 }\end{array}$ \\
\hline 305. & $\begin{array}{l}\text { If "rare" availability for female condoms above, what } \\
\text { reason(s)? } \\
\text { (select all applicable) }\end{array}$ & $\begin{array}{l}\text { 1. Inadequate quantity } \\
\text { 2. Providers not trained to } \\
\text { administer } \\
\text { 3. Inadequate equipment/tools to } \\
\text { provide services } \\
\text { 4. Other (specify reason) }\end{array}$ \\
\hline
\end{tabular}




\begin{tabular}{|c|c|c|}
\hline No. & QUESTIONS AND CODING CATEGORIES & RESPONSE \\
\hline & & $\rightarrow$ Go to Q307 \\
\hline 306. & $\begin{array}{l}\text { If "never available" for female condoms, why? } \\
\text { (select all applicable) }\end{array}$ & $\begin{array}{ll}\text { 1. } & \text { Inadequate quantity } \\
\text { 2. } & \text { Providers not trained to } \\
\text { administer } \\
\text { 3. Inadequate equipment/tools to } \\
\text { provide services } \\
\text { 4. Other (specify reason) } \\
\end{array}$ \\
\hline 307. & Pills (Oral contraceptives) & $\begin{array}{l}\text { 1. Always available } \rightarrow \text { Go to Q310 } \\
\text { 2. Sometimes available } \rightarrow \text { Go to } \\
\text { Q310 } \\
\text { 3. Rarely available } \\
\text { 4. Never available } \rightarrow \text { Go to Q309 }\end{array}$ \\
\hline 308. & $\begin{array}{l}\text { If "rare" availability for pills (oral contraceptives) above, what } \\
\text { reason(s)? } \\
\text { (select all applicable) }\end{array}$ & $\begin{array}{l}\text { 1. Inadequate quantity } \\
\text { 2. Providers not trained to } \\
\text { administer } \\
\text { 3. Inadequate equipment/tools to } \\
\text { provide services } \\
\text { 4. Other (specify reason): } \\
\rightarrow \text { Go to Q310 }\end{array}$ \\
\hline 309. & $\begin{array}{l}\text { If "never available" for pills (oral contraceptives), what } \\
\text { reason(s)? } \\
\text { (select all applicable) }\end{array}$ & $\begin{array}{l}\text { 1. Inadequate quantity } \\
\text { 2. Providers not trained to } \\
\text { administer } \\
\text { 3. Inadequate equipment/tools to } \\
\text { provide services } \\
\text { 4. Other (specify reason) }\end{array}$ \\
\hline 310. & 1-month injectables & $\begin{array}{l}\text { 1. Always available } \rightarrow \text { Go to } Q 313 \\
\text { 2. Sometimes available } \rightarrow \text { Go to } \\
\text { Q313 } \\
\text { 3. Rarely available } \\
\text { 4. Never available } \rightarrow \text { Go to Q312 }\end{array}$ \\
\hline 311. & $\begin{array}{l}\text { If "rare" availability for 1-month injectables above, what } \\
\text { reason(s)? } \\
\text { (select all applicable) }\end{array}$ & $\begin{array}{l}\text { 1. Inadequate quantity } \\
\text { 2. Providers not trained to } \\
\text { administer } \\
\text { 3. Inadequate equipment/tools to } \\
\text { provide services } \\
\text { 4. Other (specify reason) } \\
\rightarrow \text { Go to } Q 313\end{array}$ \\
\hline 312. & $\begin{array}{l}\text { If "never available" for 1-month injectables, what reason(s)? } \\
\text { (select all applicable) }\end{array}$ & $\begin{array}{l}\text { 1. Inadequate quantity } \\
\text { 2. Providers not trained to } \\
\text { administer } \\
\text { 3. Inadequate equipment/tools to } \\
\text { provide services } \\
\text { 4. Other, (specify reason) } \\
\end{array}$ \\
\hline 313. & 3-months injectables & $\begin{array}{ll}\text { 1. } & \text { Always available } \rightarrow \text { Go to } Q 316 \\
\text { 2. Sometimes available } \rightarrow \text { Go to } \\
\text { Q316 } \\
\text { 3. Rarely available (poor) } \\
\text { 4. Never available } \rightarrow \text { Go to Q315 }\end{array}$ \\
\hline 314. & $\begin{array}{l}\text { If "rare" availability for 3-months injectables above, what } \\
\text { reason(s)? } \\
\text { (select all applicable) }\end{array}$ & $\begin{array}{l}\text { 1. Inadequate quantity } \\
\text { 2. Providers not trained to } \\
\text { administer } \\
\text { 3. Inadequate equipment/tools to } \\
\text { provide services } \\
\text { 4. Other, (specify reason) } \\
\rightarrow \text { Go to Q316 }\end{array}$ \\
\hline
\end{tabular}




\begin{tabular}{|c|c|c|}
\hline No. & QUESTIONS AND CODING CATEGORIES & RESPONSE \\
\hline 315. & $\begin{array}{l}\text { If "never available" for 3-months injectables above, what } \\
\text { reason(s)? } \\
\text { (select all applicable) }\end{array}$ & $\begin{array}{ll}\text { 1. } & \text { Inadequate quantity } \\
\text { 2. } & \text { Providers not trained to } \\
\text { administer } \\
\text { 3. Inadequate equipment/tools to } \\
\text { provide services } \\
\text { 4. Other (specify reason) }\end{array}$ \\
\hline 316. & Implants & $\begin{array}{l}\text { 1. Always available } \rightarrow \text { Go to Q319 } \\
\text { 2. Sometimes available } \rightarrow \text { Go to } \\
\text { Q319 } \\
\text { 3. Rarely available } \\
\text { 4. Never available } \rightarrow \text { Go to Q318 }\end{array}$ \\
\hline 317. & $\begin{array}{l}\text { If "rare" availability for implants (rods) above, what } \\
\text { reason(s)? } \\
\text { (select all applicable) }\end{array}$ & $\begin{array}{l}\text { 1. Inadequate quantity } \\
\text { 2. Providers not trained to } \\
\text { administer } \\
\text { 3. Inadequate equipment/tools to } \\
\text { provide services } \\
\text { 4. Other (specify reason) } \\
\rightarrow \text { Go to Q319 }\end{array}$ \\
\hline 318. & If "never available" for implants (rods), what reason(s)? & $\begin{array}{l}\text { 1. Inadequate quantity } \\
\text { 2. Providers not trained to } \\
\text { administer } \\
\text { 3. Inadequate equipment/tools to } \\
\text { provide services } \\
\text { 4. Other (specify reason) } \\
\text { (select all applicable) }\end{array}$ \\
\hline 319. & IUDs & $\begin{array}{ll}\text { 1. } & \text { Always available } \rightarrow \text { Go to Q322 } \\
\text { 2. } & \text { Sometimes available } \rightarrow \text { Go to } \\
\text { Q322 } \\
\text { 3. Rarely available } \\
\text { 4. Never available } \rightarrow \text { Go to Q321 }\end{array}$ \\
\hline 320. & $\begin{array}{l}\text { If "rare" availability for IUDs above, what reason(s)? } \\
\text { (select all applicable) }\end{array}$ & $\begin{array}{ll}\text { 1. Inadequate quantity } \\
\text { 2. Providers not trained to } \\
\text { administer } \\
\text { 3. Inadequate equipment/tools to } \\
\text { provide services } \\
\text { 4. Other (specify reason)__ } \\
\rightarrow \text { Go to Q322 }\end{array}$ \\
\hline 321. & $\begin{array}{l}\text { If "never available" for IUDs, what reason(s)? } \\
\text { (select all applicable) }\end{array}$ & $\begin{array}{ll}\text { 1. } & \text { Inadequate quantity } \\
\text { 2. } & \text { Providers not trained to } \\
\text { administer } \\
\text { 3. Inadequate equipment/tools to } \\
\text { provide services } \\
\text { 4. Other (specify reason) } \\
\end{array}$ \\
\hline 322. & Female Sterilization & $\begin{array}{ll}\text { 1. } & \text { Always available } \rightarrow \text { Go to Q325 } \\
\text { 2. Sometimes available } \rightarrow \text { Go to } \\
\text { Q325 } \\
\text { 3. Rarely available } \\
\text { 4. Never available } \rightarrow \text { Go to Q324 }\end{array}$ \\
\hline 323. & $\begin{array}{l}\text { If "rare" availability for female sterilization above, what } \\
\text { reason(s)? } \\
\text { (select all applicable) }\end{array}$ & $\begin{array}{l}\text { 1. Providers not trained to } \\
\text { administer } \\
\text { 2. Inadequate equipment/tools to } \\
\text { provide services } \\
\text { 3. Other (specify reason) } \\
\rightarrow \text { Go to Q325 }\end{array}$ \\
\hline
\end{tabular}




\begin{tabular}{|c|c|c|}
\hline No. & QUESTIONS AND CODING CATEGORIES & RESPONSE \\
\hline 324. & $\begin{array}{l}\text { If "never available" for female sterilization, what reason(s)? } \\
\text { (select all applicable) }\end{array}$ & $\begin{array}{l}\text { 1. Providers not trained to } \\
\text { administer } \\
\text { 2. Inadequate equipment/tools to } \\
\text { provide services } \\
\text { 3. Other (specify reason) }\end{array}$ \\
\hline 325. & Male Sterilization & $\begin{array}{ll}\text { 1. } & \text { Always available } \rightarrow \text { Go to Q328 } \\
\text { 2. Sometimes available } \rightarrow \text { Go to } \\
\text { Q328 } \\
\text { 3. Rarely available } \\
\text { 4. Never available } \rightarrow \text { Go to Q327 }\end{array}$ \\
\hline 326. & $\begin{array}{l}\text { If "rare" availability for male sterilization above, what } \\
\text { reason(s)? } \\
\text { (select all applicable) }\end{array}$ & $\begin{array}{l}\text { 1. Providers not trained to } \\
\text { administer } \\
\text { 2. Inadequate equipment/tools to } \\
\text { provide services } \\
\text { 3. Other (specify reason) } \\
\rightarrow \text { Go to Q328 }\end{array}$ \\
\hline 327. & $\begin{array}{l}\text { If “never available” for male sterilization, what reason(s)? } \\
\text { (select all applicable) }\end{array}$ & $\begin{array}{l}\text { 1. Providers not trained to } \\
\text { administer } \\
\text { 2. Inadequate equipment/tools to } \\
\text { provide services } \\
\text { 3. Other (specify reason) }\end{array}$ \\
\hline 328. & Emergency contraceptives & $\begin{array}{ll}\text { 1. } & \text { Always available } \rightarrow \text { Go to Q331 } \\
\text { 2. Sometimes available } \rightarrow \text { Go to } \\
\text { Q331 } \\
\text { 3. Rarely available } \\
\text { 4. Never available } \rightarrow \text { Go to Q330 }\end{array}$ \\
\hline 329. & $\begin{array}{l}\text { If "rare" availability for emergency contraceptives above, } \\
\text { what reason(s)? } \\
\text { (select all applicable) }\end{array}$ & $\begin{array}{ll}\text { 1. Inadequate quantity } \\
\text { 2. Providers not trained to } \\
\text { administer } \\
\text { 3. Inadequate equipment/tools to } \\
\text { provide services } \\
\text { 4. Other (specify reason) } \\
\rightarrow \text { Go to Q331 }\end{array}$ \\
\hline 330. & $\begin{array}{l}\text { If “never available” for emergency contraceptives, what } \\
\text { reason(s)? } \\
\text { (select all applicable) }\end{array}$ & $\begin{array}{ll}\text { 1. } & \text { Inadequate quantity } \\
\text { 2. } & \text { Providers not trained to } \\
\text { administer } \\
\text { 3. Inadequate equipment/tools to } \\
\text { provide services } \\
\text { 4. Other (specify reason) }\end{array}$ \\
\hline 331. & Natural methods e.g., Cycle beads & $\begin{array}{ll}\text { 1. } & \text { Always available } \rightarrow \text { Go to Q334 } \\
\text { 2. } & \text { Sometimes available } \rightarrow \text { Go to } \\
\text { Q334 } \\
\text { 3. } \\
\text { 4. } \\
\text { Rarely available } \\
\end{array}$ \\
\hline 332. & $\begin{array}{l}\text { If "rare" availability for natural methods above, what } \\
\text { reason(s)? } \\
\text { (select all applicable) }\end{array}$ & $\begin{array}{l}\text { 1. Inadequate quantity } \\
\text { 2. Providers not trained to } \\
\text { administer } \\
\text { 3. Inadequate equipment/tools to } \\
\text { provide services } \\
\text { 4. Other (specify reason) } \\
\rightarrow \text { Go to Q334 } \\
\end{array}$ \\
\hline 333. & $\begin{array}{l}\text { If “never available” for cycle beads, what reason(s)? } \\
\text { (select all applicable) }\end{array}$ & $\begin{array}{ll}\text { 1. } & \text { Inadequate quantity } \\
\text { 2. } & \text { Providers not trained to } \\
\text { administer } \\
\text { 3. Inadequate equipment/tools to } \\
\text { provide services } \\
\text { 5. Other (specify reason) } \\
\end{array}$ \\
\hline
\end{tabular}




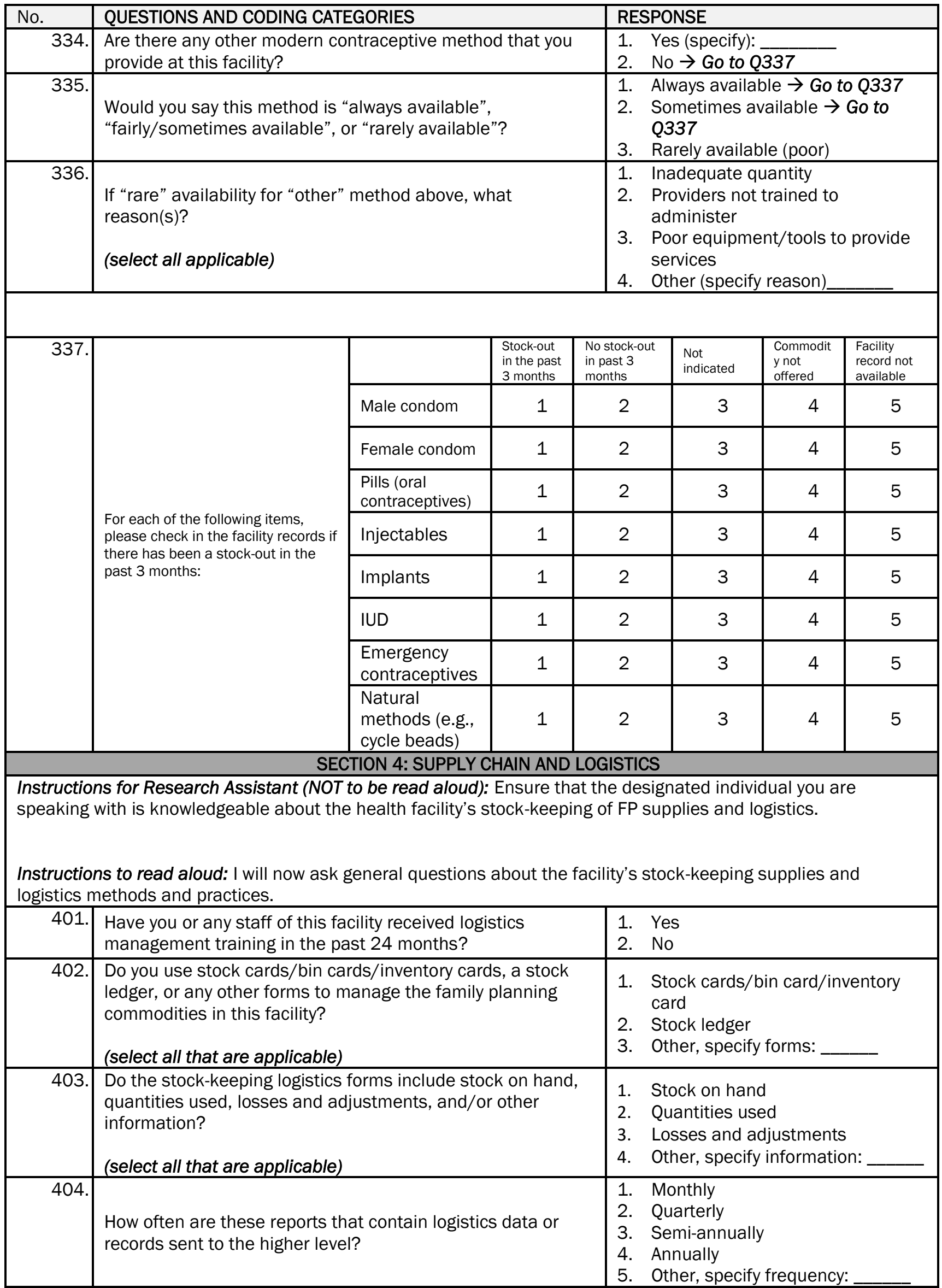




\begin{tabular}{|c|c|c|c|c|}
\hline No. & QUESTIONS AND CODING CATEGORIES & \multicolumn{3}{|l|}{ RESPONSE } \\
\hline 405. & $\begin{array}{l}\text { When was the last time you requested for family planning } \\
\text { commodities at this facility? }\end{array}$ & \multicolumn{3}{|c|}{$\begin{array}{l}\text { 1. Less than one month ago } \\
\text { 2. } 1-2 \text { months ago } \\
\text { 3. } 3 \text { months ago } \\
\text { 4. More than } 3 \text { months ago } \\
\text { 5. Never } \rightarrow \text { Go to Q407 }\end{array}$} \\
\hline 406. & $\begin{array}{l}\text { On average, approximately how long does it take between } \\
\text { ordering and receiving family planning commodities? }\end{array}$ & \multicolumn{3}{|c|}{$\begin{array}{l}\text { 1. Less than } 2 \text { weeks } \\
\text { 2. } 2 \text { weeks to } 1 \text { month } \\
\text { 3. Between } 1 \text { and } 2 \text { months } \\
\text { 4. } \text { More than } 2 \text { months }\end{array}$} \\
\hline 407. & $\begin{array}{l}\text { Which authority determines this facility's family planning } \\
\text { commodities re-supply quantities? }\end{array}$ & \multicolumn{3}{|c|}{$\begin{array}{ll}\text { 1. } & \text { The facility itself } \\
\text { 2. Higher-level facility } \\
\text { 3. District Health Management Team } \\
\text { 4. } \text { Other, specify: } \\
\end{array}$} \\
\hline 408. & $\begin{array}{l}\text { How are the facility's family planning commodities re-supply } \\
\text { quantities determined? }\end{array}$ & \multicolumn{3}{|c|}{$\begin{array}{l}\text { 1. Calculated using formula } \\
\text { 2. Remaining stock } \\
\text { 3. Stipulated ration } \\
\text { 4. Other means, specify: } \\
\end{array}$} \\
\hline \multicolumn{5}{|c|}{ SECTION 5: ESSENTIAL FAMILY PLANNING EQUIPMENT AND SUPPLIES } \\
\hline \multicolumn{5}{|c|}{$\begin{array}{l}\text { Instructions to read aloud: This section of the questionnaire is to better understand the supplies and materials } \\
\text { that are available at this facility. I have a checklist to complete. Please take me to the area where the Family } \\
\text { Planning supplies are stored and administered. }\end{array}$} \\
\hline 501. & \multicolumn{4}{|c|}{$\begin{array}{l}\text { Instructions for Research Assistant (NOT to be read aloud): For the following supplies and materials, } \\
\text { observe and indicate whether (select one for each): } \\
\text { (1) equipment/commodity is available and working; } \\
\text { (2) equipment/commodity is available but NOT working; } \\
\text { (3) equipment/commodity is not available. }\end{array}$} \\
\hline & & 1 & 2 & 3 \\
\hline \multicolumn{5}{|c|}{ a. Spotlight source (flashlight or examination light) } \\
\hline \multicolumn{5}{|c|}{ b. Couch/bed and stool for examination \& procedures } \\
\hline \multicolumn{5}{|c|}{ c. Table/trolley for tray setup } \\
\hline \multicolumn{5}{|c|}{ d. $\quad$ Blood pressure apparatus } \\
\hline \multicolumn{5}{|c|}{ e. Stethoscope } \\
\hline \multicolumn{5}{|c|}{ f. Weighing scale } \\
\hline \multicolumn{5}{|c|}{ g. $\quad$ Sterile needle and syringe } \\
\hline \multicolumn{5}{|c|}{ h. Armrest for Implant insertion } \\
\hline \multicolumn{5}{|c|}{ i. Vaginal speculum } \\
\hline \multicolumn{5}{|c|}{ j. $\quad$ Tenaculum } \\
\hline \multicolumn{5}{|c|}{ k. Sponge Holding forceps } \\
\hline \multicolumn{5}{|c|}{ I. $\quad$ kidney Dishes } \\
\hline \multicolumn{5}{|c|}{ m. Curved Mosquito Artery Forceps } \\
\hline \multicolumn{5}{|c|}{ n. Gallipots } \\
\hline \multicolumn{5}{|c|}{ o. Uterine Sound } \\
\hline \multicolumn{5}{|c|}{ p. $\quad$ Alligator Forceps } \\
\hline \multicolumn{5}{|c|}{ q. Soap for handwashing } \\
\hline \multicolumn{5}{|c|}{ r. Single-use towel/Disposable tissue } \\
\hline \multicolumn{5}{|c|}{ s. Flowing water or veronica bucket for handwashing } \\
\hline \multicolumn{5}{|c|}{$\begin{array}{l}\text { t. Decontamination solution for clinical equipment (chlorine) with } 0.5 \\
\text { concentration }\end{array}$} \\
\hline \multicolumn{5}{|c|}{ u. Plastic buckets for decontamination } \\
\hline V. $\mathrm{D}$ & Disposable gloves/Sterile gloves & & & \\
\hline W. S & Safety box / Yellow box / Sharps box & & & \\
\hline $\mathrm{X} . \mathrm{W}$ & Naste bin (hard-sided, pedal-operated) & & & \\
\hline y. $\quad \mathrm{Li}$ & ining for waste bin & & & \\
\hline Z. $\mathrm{A}$ & Antiseptic (e.g., Savlon \& lodine) & & & \\
\hline
\end{tabular}


SECTION 5 (a): HUMAN RESOURCES - STAFF VOLUMES

Table 1: Facility Staff Volumes

Instructions to read aloud: For this next section, I'm going to ask you to indicate the number of staff at this facility, broken down into groups based on clinical experience and certification. I'll ask that you list the total number of staff for each position type, the number trained in family planning service provision, and the number providing FP services.

502.

a.

b. Medical or Physician assistant

c. $\quad$ Public Health Nurse

d. $\quad$ Midwife

e. $\quad$ State Registered Nurse

\begin{tabular}{l|l}
\hline f. & Community Health Nurse \\
\hline
\end{tabular}

g. $\quad$ Enrolled Nurse

h. $\quad$ Pharmacist

\begin{tabular}{|l|l}
\hline i. & Other staff (specify type) \\
\hline
\end{tabular} 


\begin{tabular}{|c|c|c|c|c|c|c|c|c|c|c|c|c|c|c|}
\hline \multicolumn{15}{|c|}{ Instructions to read aloud: For this chart, please indicate whether, at this facility, the indicated provider type provides the under-listed service and/or method. } \\
\hline 503. & & $\begin{array}{l}\text { FP } \\
\text { counseling }\end{array}$ & $\begin{array}{l}\text { Male } \\
\text { Condom }\end{array}$ & $\begin{array}{l}\text { Female } \\
\text { condom }\end{array}$ & $\begin{array}{l}\text { Oral } \\
\text { contraceptives } \\
\text { (Pills) }\end{array}$ & $\begin{array}{l}\text { 1-month } \\
\text { Injectables }\end{array}$ & $\begin{array}{l}\text { 3-months } \\
\text { injectables }\end{array}$ & Implants & IUD & $\begin{array}{l}\text { Female } \\
\text { sterilization }\end{array}$ & $\begin{array}{l}\text { Male } \\
\text { sterilization }\end{array}$ & $\begin{array}{l}\text { Emerge } \\
\text { ncy } \\
\text { Contrac } \\
\text { eptives }\end{array}$ & $\begin{array}{l}\text { Cycle } \\
\text { bead } \\
\mathrm{s}\end{array}$ & None \\
\hline a. & Doctor & & & & & & & & & & & & & \\
\hline b. & $\begin{array}{l}\text { Medical or } \\
\text { Physician } \\
\text { assistant }\end{array}$ & & & & & & & & & & & & & \\
\hline c. & $\begin{array}{l}\text { Public } \\
\text { Health } \\
\text { Nurse }\end{array}$ & & & & & & & & & & & & & \\
\hline d. & Midwife & & & & & & & & & & & & & \\
\hline e. & $\begin{array}{l}\text { State } \\
\text { Registered } \\
\text { Nurse }\end{array}$ & & & & & & & & & & & & & \\
\hline f. & $\begin{array}{l}\text { Community } \\
\text { Health } \\
\text { Nurse }\end{array}$ & & & & & & & & & & & & & \\
\hline g. & $\begin{array}{l}\text { Enrolled } \\
\text { Nurse }\end{array}$ & & & & & & & & & & & & & \\
\hline h. & Pharmacist & & & & & & & & & & & & & \\
\hline i. & $\begin{array}{l}\text { Other staff } \\
\text { (specify } \\
\text { type) }\end{array}$ & & & & & & & & & & & & & \\
\hline
\end{tabular}




\section{Section 5 (c) - HUMAN RESOURCES - STAFF TRAINING}

Table 3: Provider Types and Services/Methods Training

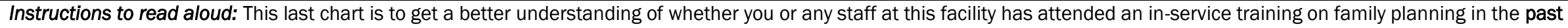
two years. For each provider-type listed and each Family planning service and/or contraceptive method, please indicate whether or not the providers have attended any service training for that service or contraceptive method in the past two years.

\begin{tabular}{|c|c|c|c|c|c|c|c|c|c|c|c|c|c|c|c|}
\hline 504. & ( & \begin{tabular}{|l|} 
FP \\
counseling
\end{tabular} & $\begin{array}{l}\text { Male } \\
\text { condoms }\end{array}$ & $\begin{array}{l}\text { Female } \\
\text { condoms }\end{array}$ & $\begin{array}{l}\text { Oral } \\
\text { contracep } \\
\text { tives } \\
\end{array}$ & Injectable & Implants & IUD & $\begin{array}{l}\text { Female } \\
\text { sterilization }\end{array}$ & $\begin{array}{l}\text { Male } \\
\text { sterilizatio } \\
\mathrm{n}\end{array}$ & $\begin{array}{l}\text { Emergency } \\
\text { contraceptive } \\
\mathrm{s}\end{array}$ & $\begin{array}{l}\text { Natural } \\
\text { methods } \\
\text { (cycle beads) }\end{array}$ & $\begin{array}{l}\text { Infection } \\
\text { prevention }\end{array}$ & STI counseling & None \\
\hline a. & Doctor & & & & & & & & & & & & & & \\
\hline b. & $\begin{array}{l}\text { Medical or Physician } \\
\text { assistant }\end{array}$ & & & & & & & & & & & & & & \\
\hline c. & Public Health Nurse & & & & & & & & & & & & & & \\
\hline d. & Midwife & & & & & & & & & & & & & & \\
\hline e. & State Registered Nurse & & & & & & & & & & & & & & \\
\hline $\mathrm{f}$. & Community Health Nurse & & & & & & & & & & & & & & \\
\hline g. & Enrolled Nurse & & & & & & & & & & & & & & \\
\hline h. & Pharmacist & & & & & & & & & & & & & & \\
\hline i. & Other staff (specify type) & & & & & & & & & & & & & & \\
\hline
\end{tabular}




\begin{tabular}{|c|c|c|c|c|c|}
\hline \multicolumn{6}{|c|}{$\begin{array}{l}\text { Instructions to read aloud: Thank you very much for generously taking the time to complete this } \\
\text { questionnaire with me. As a last and final step, I am going to ask questions about how this facility records } \\
\text { and reports family planning data. }\end{array}$} \\
\hline No. & \multicolumn{3}{|c|}{ QUESTIONS AND CODING CATEGORIES } & \multicolumn{2}{|l|}{ RESPONSE } \\
\hline 601. & \multicolumn{3}{|c|}{$\begin{array}{l}\text { Is family planning offered in different units in this } \\
\text { facility? }\end{array}$} & \multicolumn{2}{|c|}{$\begin{array}{ll}\text { 1. } & \text { Yes } \\
\text { 2. } & \text { No } \rightarrow \text { Go to } Q 605\end{array}$} \\
\hline 602. & \multicolumn{3}{|c|}{$\begin{array}{l}\text { CHECK, IF Q601 is “YES” } \\
\text { ASK, if family planning is offered in different units, } \\
\text { does each of the units have a register/logging } \\
\text { system for family planning service records? }\end{array}$} & \multicolumn{2}{|c|}{$\begin{array}{ll}\text { 1. } & \text { Yes } \\
\text { 2. No } \rightarrow \text { Go to } Q 605\end{array}$} \\
\hline 603. & \multicolumn{3}{|c|}{$\begin{array}{l}\text { How does this facility collate all family planning } \\
\text { records together? } \\
\text { (select all that are applicable) }\end{array}$} & \multicolumn{2}{|c|}{$\begin{array}{l}\text { 1. A dedicated person goes around the } \\
\text { units to collate the records } \\
\text { 2. Someone from the unit brings the } \\
\text { records to the main FP unit } \\
\text { 3. No one collates the FP records from } \\
\text { different units } \\
\text { 4. Other (specify) }\end{array}$} \\
\hline 604. & \multicolumn{3}{|c|}{$\begin{array}{l}\text { If FP records from different units are collated, at } \\
\text { what interval is this done? }\end{array}$} & \multicolumn{2}{|c|}{$\begin{array}{ll}\text { 1. } & \text { Every day } \\
\text { 2. } & \text { Every week } \\
\text { 3. Once a month } \\
\text { 4. Twice a month } \\
\text { 5. Every quarter } \\
\text { 6. Only when we are preparing a report } \\
\text { 7. Never } \\
\text { 8. Other (specify) }\end{array}$} \\
\hline 605. & \multicolumn{3}{|c|}{$\begin{array}{l}\text { How is family planning data recorded in this facility? } \\
\text { (select all applicable) }\end{array}$} & \multicolumn{2}{|c|}{$\begin{array}{l}\text { 1. Family planning register } \\
\text { 2. Family planning daily logbook } \\
\text { 3. e-Tracker } \\
\text { 4. rsLog } \\
\text { 5. Other (specify) }\end{array}$} \\
\hline 606. & \multicolumn{3}{|c|}{$\begin{array}{l}\text { How is the family planning data reported in this } \\
\text { facility? } \\
\text { (select all applicable) }\end{array}$} & \multicolumn{2}{|c|}{$\begin{array}{l}\text { 1. Monthly report forms } \\
\text { 2. District Health Information } \\
\text { Management System (DHIMS) } \\
\text { 3. Other (specify) }\end{array}$} \\
\hline 607. & \multicolumn{3}{|c|}{$\begin{array}{l}\text { Observe the family planning clients register. Are all } \\
\text { columns filled correctly and completely? }\end{array}$} & \multicolumn{2}{|l|}{$\begin{array}{l}\text { 1. Yes } \\
\text { 2. No }\end{array}$} \\
\hline 608. & \multicolumn{3}{|c|}{$\begin{array}{l}\text { Observe the monthly reports on family planning. Are } \\
\text { the monthly reports up-to-date, complete and reflect } \\
\text { daily services register? }\end{array}$} & \multicolumn{2}{|l|}{$\begin{array}{ll}\text { 1. } & \text { Yes } \\
\text { 2. } & \text { No }\end{array}$} \\
\hline $\begin{array}{l}\text { TIME } \\
\text { (use } t\end{array}$ & 2-hour clock) & Hour: & Minutes: & AM/PM: & \\
\hline
\end{tabular}

To read aloud: Thank you very much for your time. The information you have provided is very helpful. All information collected today will be kept strictly confidential, but the information gathered today will be very helpful for a better understanding of family planning services throughout Ghana. 